Finance and Economics Discussion Series Divisions of Research \& Statistics and Monetary Affairs Federal Reserve Board, Washington, D.C.

\title{
Integrated Macroeconomic Accounts for the United States: Draft SNA-USA
}

\author{
Rochelle Antoniewicz, Susan Hume McIntosh, Charles Ian Mead, \\ Karin Moses, Brent Moulton, Michael Palumbo, Genevieve Solomon, \\ and Albert M. Teplin \\ 2004-54
}

NOTE: Staff working papers in the Finance and Economics Discussion Series (FEDS) are preliminary materials circulated to stimulate discussion and critical comment. The analysis and conclusions set forth are those of the authors and do not indicate concurrence by other members of the research staff or the Board of Governors. References in publications to the Finance and Economics Discussion Series (other than acknowledgement) should be cleared with the author(s) to protect the tentative character of these papers. 


\title{
INTEGRATED MACROECONOMIC ACCOUNTS FOR THE UNITED STATES: DRAFT SNA-USA
}

\author{
A JOINT PROJECT OF THE \\ BOARD OF GOVERNORS OF THE FEDERAL RESERVE SYSTEM AND \\ THE BUREAU OF ECONOMIC ANALYSIS
}

Paper prepared for Conference on Research in Income and Wealth

Architecture of National Accounts

April 16-17, 2004

Washington, D.C.

Current Version: July 2004

Albert M. Teplin (CSE Analysis),

Rochelle Antoniewicz, Susan Hume McIntosh, Michael Palumbo, and Genevieve Solomon (Board of Governors of the Federal Reserve System)*

Charles Ian Mead, Karin Moses, Brent Moulton (Bureau of Economic Analysis, U.S. Department of Commerce)*

\footnotetext{
*The analysis and conclusions set forth are those of the authors and do not indicate concurrence by other members of their respective research staffs, the Board of Governors of the Federal Reserve System, the Bureau of Economic Analysis, or the Department of Commerce. Data in this publication are estimates based on incomplete source material and are not official figures of the U.S. Government or the Federal Reserve System.
} 


\title{
Integrated Macroeconomic Accounts for the United States: Draft SNA-USA
}

\author{
Albert M. Teplin: CSE Analysis \\ Rochelle Antoniewicz, Susan Hume McIntosh, Michael G. Palumbo, and Genevieve Solomon: \\ Federal Reserve Board \\ Charles Ian Mead, Karin Moses, and Brent R. Moulton: Bureau of Economic Analysis
}

Abstract: This paper presents integrated macroeconomic accounts for the United States for the period 1985 to 2002 and discusses issues related to their construction and use. Specifically, it focuses on tying together the national income and product accounts (NIPAs) and international transaction accounts (ITA) published by the Bureau of Economic Analysis and the flow of funds accounts (FFA) published by the Federal Reserve Board. The paper provides integrated accounts for seven sectors: households and nonprofit organizations serving households, nonfinancial noncorporate businesses, nonfinancial corporate businesses, financial businesses, federal government, state and local governments, and the rest of the world. Each sector table has a full complement of accounts: current accounts (production and income accounts), accumulation accounts (capital account, financial account, and other changes in volume account), revaluation account, and balance sheet account. As a result, the sector statements trace the factors leading to changes in sector net worth. Relative to current publications of the two agencies, the tables go quite a bit further toward providing for the United States the sequence of accounts suggested in the System of National Accounts 1993 (SNA93), the recognized international standard. The tables use official data as of June 10, 2004; however, a few series have been created by the authors, and they are unofficial preliminary estimates at this time. 


\section{INTRODUCTION}

This paper reports on an ongoing effort at the Federal Reserve Board (FRB) and the Bureau of Economic Analysis (BEA), henceforth the agencies, to integrate the nation's macroeconomic accounts. BEA publishes the national income and product accounts (NIPA) and international transaction accounts (ITA). The NIPA conveys production and income flows in the United States - the current accounts. The NIPA also includes data on the accumulation and value of tangible assets. The presentation in the NIPA is heaviest on national aggregates, with a mixture of sector and transaction detail. The ITA records the nation's transactions and balances with the rest of the world. It provides detail on the U.S. external position and changes in that position, in many cases by region and country.

The FRB publishes the flow of funds accounts (FFA). The focus of the presentation is on sector activity. For each sector, the FFA combines a capital account (showing saving and capital expenditures) and a financial account (showing net acquisition of financial assets and net incurrence of liabilities). The FFA includes detail on flows of financial instruments and stocks of financial assets and liabilities. For certain private sectors, the FFA has balance sheets, which combine information on tangible assets with stocks of financial assets and liabilities. The FFA offers considerable detail for specific financial instruments, such as mortgages, corporate bonds, and deposits.

The three published accounts - NIPA, ITA, and FFA — are major elements of a full set of integrated national accounts outlined in standards developed by a consortium of international agencies and published as the System of National Accounts 1993 (SNA93). ${ }^{1}$ The U.S. accounts provide a long history of macroeconomic activity, using a consistent methodology, and with a level of detail and quality rarely matched in accounts of other countries. The publications are available quarterly and are produced in a timely fashion.

Over the past decade, many changes to the U.S. accounts have moved them closer to SNA93 standards. For example, in the NIPA comprehensive revision that was released in December 2003, the tables and definition of transactions were changed to make them much more consistent with SNA93. ${ }^{2}$ Nonetheless, the agencies and the user public have recognized that the

\footnotetext{
${ }^{1}$ System OF NATIONAL ACCOUNTS 1993, prepared under the auspices of the Inter-Secretariat Working Group on National Accounts, Commission of the European Communities-Eurostat, International Monetary Fund, Organization for Economic Co-operation and Development, United Nations, and World Bank (1993).

${ }^{2}$ Brent R. Moulton and Eugene P. Seskin, "Preview of the 2003 Comprehensive Revision of the National Income and Product Accounts: Changes in Definitions and Classifications," SURVEY OF CURRENT BusINESS, vol. 83 (June 2003), 17-34; and Nicole Mayerhauser, Shelly Smith, and David F. Sullivan,
} 
accounts could be more fully integrated. ${ }^{3}$ Closer coordination between the agencies would ensure that certain critical elements - such as sector boundaries, alternative data sources, and treatment of transactions - are handled in a way that minimizes distortions to important analytical concepts. Integration likely would align U. S. statistics more closely with those of other nations, and allow policymakers and researchers to analyze more fully and accurately the interrelationships of the nation's financial and nonfinancial activities. Integration of the accounts also would provide a common terminology and a uniform presentation that highlighted connections between the activities described in separate accounts.

The U.S. effort toward a better or more fully integrated set of economic accounts has a long history. Particularly noteworthy was a attempt at such accounts undertaken by Richard Ruggles and Nancy Ruggles about a quarter century ago. ${ }^{4}$ While retaining much of the existing account structure, they showed a framework for all economic statistics that embraced both stocks and flows using the then-existing NIPA, ITA, and FFA. The commentary on their effort highlighted significant conceptual issues and considerable disagreement on the form of such accounts. Some of those issues and disagreements remain; but over the years, international consensus, published in SNA93, have eliminated many.

Given the consensus, our work focuses on the actual production of accounts. With regard to the Ruggles's 1982 paper, James Tobin noted that "their experiment ... illustrate[d] the wellknown problem. It is difficult to reconcile data from the different sources, and disturbingly large, unexplained discrepancies remain...Conceptual integration needs to be matched by a concerted effort to diagnose and remedy these inconsistencies."

Diagnosing and remedying inconsistencies has been our goal. Indeed, preparing this paper, including the attached tables, is perhaps the most significant joint effort on the accounts since the Tobin comment was made. The agencies have looked closely at sector boundaries and the nature of discrepancies that arise from using different data sources, judgmental adjustments, and estimating techniques. We have uncovered many issues and have solved a few; others remain for future work.

"Preview of the 2003 Comprehensive Revision of the National Income and Product Accounts: New and Redesigned Tables," vol. 83 (August 2003), 7-31.

${ }^{3}$ For example, references to the integration of the NIPA and FFA are contained both in general and specific terms in "BEA's Strategic Plan for FY 2001-2005," SURVEY OF CURRENT BUSINESS, vol. 82, (May 2002), $8-32$.

${ }^{4}$ Richard Ruggles and Nancy D. Ruggles, "Integrated Economic Accounts for the United States, 1947-80," SURVEY OF CURRENT BUSINESS, vol. 62 (May 1982), 1-53. Discussion by other experts is contained in pages 54-75.

${ }^{5}$ Ibid, 74. 
We have also considered ways to present the vast amount of data that lie within integrated accounts. As matters stand, the FFA quarterly release is more than a hundred pages and the number of tables in the NIPA and ITA could easily fill an equal number of pages. Even if done parsimoniously and coherently, a combined set of accounts likely will require considerable navigation by the user.

Other countries and economic areas are in various stages of providing a fully integrated set of macroeconomic accounts. Canada, for example, has published integrated accounts for some time. The integration extends to benchmarking to the input-output accounts. Moreover, within Statistics Canada, there is coordination so that common estimation methods are used among the accounts; and, where issues arise, implications are considered for the full range of accounts, rather than a single portion. ${ }^{6}$

Eurostat provides a coordinating role within Europe. They have published standards in the European System of Accounts (ESA95) patterned on SNA93. EU member countries are legally required to meet the standards for national income and product accounts and financial accounts over a set time schedule. They are requested to transmit regularly annual financial and nonfinancial accounts to Eurostat. The European Central Bank is coordinating development of quarterly financial accounts for the euro area, and, thus far, countries have provided quarterly national data, which are used, together with other euro area financial statistics, to compile a subset of quarterly Monetary Union financial accounts for nonfinancial sectors, insurance companies, and pension funds. They are working toward expanding the integrated system to seven sectors - households, nonfinancial corporations, government, monetary financial institutions, insurance corporations and pension funds, other financial intermediaries, and the rest of the world.

International agencies are also providing impetus to the efforts. The IMF guides and manuals for national statistics are increasingly ensuring that accounting and other elements are consistent with SNA93 standards. ${ }^{7}$ Moreover, international agencies have sponsored ongoing committees and conferences during which issues pertaining to SNA93 standards are addressed.

\footnotetext{
${ }^{6}$ A more thorough description of three counties integrated accounts is provided in a paper by Karen Wilson (2004), "The Architecture of the System of National Accounts: A Three-Way International Comparison of Canada, Australia, and the United Kingdom."

${ }^{7}$ Examples include QuARTERly National AcCounts MANual, ConcePts, Data Sources, AND Compilation, by Adriann M. Bloem, Robert J.Dipplesman, and Nils Ø. Mæhle, (Washington, D.C., International Monetary Fund, 2001); MONETARY AND FinANCIAL STATISTICs MANUAL, (Washington, D.C., International Monetary Fund, 2000); and BALANCE OF PAYMENTS COMPILATION GUIDE, (Washington, D.C., International Monetary Fund, 1995).
} 
Currently, an effort is underway to update SNA93. The OECD is coordinating dissemination of integrated accounts among member countries.

The next section of this paper offers an overview of the contents of an integrated set of accounts and reviews how those accounts are related to current publications in the U.S. Section III discusses draft SNA-USA sector tables produced with the recent data in the NIPA, ITA, and FFA. Section IV highlights several issues that affect the quality of the accounts, mainly those dealing with the statistical discrepancies between the capital and financial accounts. Section V has a few concluding comments.

\section{WHAT ARE INTEGRATED ACCOUNTS AND WHERE DO WE STAND WITH CURRENT Publications?}

The SNA93 structure envisions separate statements for sectors of the economy. Each statement contains accounts for production, income, saving, investment, and financial flows for that sector. Those sector flow accounts are combined with information on changes in value of assets and liabilities due to factors not related directly to production and saving. All together, the integrated accounts offer a means to track the sources of change in sectors' net worth; the SNA93 structure begins with a balance sheet position and fully explains how that position evolves. Along the way, it provides detail on transactions, the distribution of income by factors of production, saving, capital formation, financial intermediation, and other aspects of national and sector economic activity.

The types of accounts are listed in text table A, along with comments on how each account relates to what is currently published. The first, the current account, is comprised of production and income sub accounts that provide the familiar measures for gross domestic product (GDP), national income, and their components.

Although there are nearly three-hundred NIPA tables that provide extensive detail on the flows underlying the major aggregates, there are still some gaps relative to what would be needed for a complete set of integrated accounts. In addition to what is currently in the NIPA, the integrated accounts envision providing such information by major sectors and subsectors. In the production account, SNA93 recommends a presentation of gross output, intermediate consumption, and value added by each sector. BEA provides this type information by industry in its input-output and GDP-by-industry accounts, and provides value-added information by sector in tables 1.3.5 and 1.14. However, the NIPA tables do not provide information on gross output or intermediate consumption for nongovernment sectors. The more familiar presentation of GDP in NIPA table 1.1.5, though, presents it as the sum of final expenditures (a calculation that SNA93 
presents only in the input-output or "supply-use" tables). The SNA93 distribution and use of income accounts are similar to the NIPA private enterprise income, personal income and outlay, government receipts and expenditures, and foreign transactions accounts, but would show more detail on financial and nonfinancial corporations and noncorporate business. Published integrated accounts may retain the information shown on these or similar tables, but they would also clearly derive the saving for each sector and for the total economy.

The most important shortcoming of the NIPA relative to the integrated accounts envisioned by SNA93 is an inconsistency in sector definitions between the production account and the distribution and use of income account. While SNA93 calls for using consistently defined sectors throughout, the sectors emphasized in the NIPA production account differ from those presented in the distribution and use of income accounts. The NIPA production account, as shown in table 1.3.5, presents three major domestic sectors-business (including private and government noncorporate business), general government, and households and institutions. In contrast, the distribution and use of income accounts feature a personal sector (which includes income derived from private noncorporate business), a government account (which includes government business enterprises--that is, the full public sector), and, implicitly, a corporate business sector, which is defined by corporate legal form of organization (presented in table 1.14). Some production information is presented for corporate business, but these estimates are based on the income approach, and, therefore, differ from the expenditure-approach estimates for the other production account sectors. Consequently, the statistical discrepancy between these two types of estimates prevents the derivation of an estimate of value-added for the noncorporate business sector as the difference between value-added for corporate business and for the full business sector. Developing estimates for a consistent set of sectors is a major objective of this paper. $^{8}$

A second set of accounts is accumulation accounts. Much of the information for the capital account, the first accumulation account, is provided in the current NIPA. Data for capital outlays and saving are compiled by major sectors. Although not currently labeled as such, FFA sector statements typically begin with a capital account. However, the terminologies in the NIPA and FFA are not consistent with each other, among the sectors, or with that in SNA93.

Financial accounts, the mainstay of the FFA, are available in considerable detail. The FFA tables offer information for more than thirty sectors, many of which are financial intermediaries. Data for about fifty instruments are published in the FFA, with a separate set of

\footnotetext{
${ }^{8}$ See also Kishori Lal, "Measurement of Output, Value Added, GDP in Canada and the United States: Similarities and Differences," Research paper 13F0031MIE-No.010, Statistics Canada (June 2003).
} 
tables describing the issuers and purchasers of each instrument. Again, the terminology in the tables differs from international norms and the organization of the tables varies slightly among sectors.

SNA93 structure has additional accumulation accounts for revaluations of stocks and changes in volume of stocks due to neither holding gains and losses nor net purchases. The information in the U.S for revaluation accounts and other changes in volume accounts is less developed than that for other types of flows. The FFA reconciliation tables enumerate factors that lead to changes in net worth. They estimate holding gains and losses for equity, real estate, and other instruments and other factors that change the level of assets and liabilities. The ITA also provides figures in some tables on revaluations due to currency and price changes of assets and liabilities.

The SNA format envisions balance sheet positions for each sector. The FFA publishes balance sheet tables for three sectors - the household and nonprofit organizations sector, nonfinancial noncorporate business sector, and nonfinancial corporate business sector. For other sectors in the FFA, balance sheet data are limited to financial assets and liabilities. The necessary information for tangible assets of private subsectors has not been fully developed; and, of course, there are many issues concerning valuation of tangible assets of governments other than reproducible assets.

The listing in table A implies most of the elements of integrated accounts are in currently published material, although the missing pieces are critical in many instances. Moreover, data for some elements are incomplete or thin. Sophisticated users of the NIPA, ITA, and FFA likely are aware that this is the case, but because the information is diffused over different publications, there is a perception by a new or occasional user that the accounts are unrelated. Use of the combined accounts is cumbersome, at best. For anyone analyzing international transactions for example, the differences between the FFA rest of world sector and BEA's international transactions tables seem enormous. In fact, they are not, as both agencies rely on the same information, but present it differently. Less well known are the inconsistencies between accounts that remain in the published data and the dangers of drawing analytical conclusions from a combination of the accounts. 


\section{DRAFT SNA-USA TABLES}

This section presents draft SNA-USA tables, an integration of the agencies' accounts. We were able to construct virtually all the series required from existing data in the NIPA, ITA, and FFA. In those instances where information was incomplete, we made estimates. We are reasonably confident that the figures in the tables are near what would be derived from a more sustained effort, but they remain unofficial estimates from the agencies.

Each sector table is lengthy, and the accounts are quite a bit to absorb in a single sitting, even though we have limited them to the major sectors. Little attempt was made at this stage to whittle down the information to ease the presentation, because a goal is to understand and show the structure of the accounts. We maintained the traditional time series format, with tables that have annual figures for 1985 to $2002 .{ }^{9}$ The estimates are based on official data available on June $10,2004 .^{10}$

In draft SNA-USA, the economy is divided into five sectors- - households and nonprofit institutions serving households, nonfinancial business, financial business, government, and the rest of the world (text table B). Draft SNA-USA tables show subsectors for nonfinancial corporate business, nonfinancial noncorporate business, federal government and state and local governments.

\footnotetext{
${ }^{9}$ The draft SNA-USA tables 1 through 9 appended to this paper show the year 1995 through 2002. A companion set of tables for 1985-1994 and data for all years in CSV format are available from the authors.

${ }^{10}$ June 10, 2004 marked the release of the FFA for 2004:Q1 and revisions to prior periods. Preliminary estimates of the NIPA for 2004:Q1 were published on May 27, 2004. International transaction accounts for 2003 were made available on March 12, 2004; revisions made after June 10, 2004 are not reflected in draft SNA-USA.
} 


\begin{tabular}{|c|c|c|c|c|}
\hline \multicolumn{5}{|c|}{ TABLE A: STRUCTURE OF INTEGRATED MACROECONOMIC ACCOUNTS } \\
\hline ACCOUNT & $\begin{array}{c}\text { SUB } \\
\text { ACCOUNTS }\end{array}$ & WHAT IT SHOWS & $\begin{array}{c}\text { WHAT IS } \\
\text { PUBLISHED NOW }\end{array}$ & $\begin{array}{l}\text { SIGNIFICANT } \\
\text { ISSUES }\end{array}$ \\
\hline \multirow[b]{2}{*}{ Current } & Production & $\begin{array}{l}\text { Gross value added and consumption } \\
\text { of fixed capital by sector. For the } \\
\text { economy as a whole, sum is Gross } \\
\text { (Net) Domestic Product }\end{array}$ & $\begin{array}{l}\text { National aggregates in } \\
\text { the NIPA with some } \\
\text { sector detail. }\end{array}$ & $\begin{array}{l}\text { Gross output and } \\
\text { intermediate } \\
\text { consumption not } \\
\text { available for non- } \\
\text { government sectors. } \\
\text { No production accounts } \\
\text { for subsectors. }\end{array}$ \\
\hline & $\begin{array}{l}\text { Distribution and } \\
\text { use of income, } \\
\text { including } \\
\text { saving }\end{array}$ & $\begin{array}{l}\text { Generation of income within sectors } \\
\text { and payment to factors of } \\
\text { production supplied by other } \\
\text { sectors. Shows taxes and transfers. } \\
\text { Use of income provides a derivation } \\
\text { of saving as difference between } \\
\text { disposable income and } \\
\text { consumption. }\end{array}$ & $\begin{array}{l}\text { National aggregates in } \\
\text { NIPA with some sector } \\
\text { detail. }\end{array}$ & $\begin{array}{l}\text { Accounts for some } \\
\text { financial subsectors not } \\
\text { provided. }\end{array}$ \\
\hline \multirow{4}{*}{ Accumulation } & Capital & $\begin{array}{l}\text { Capital outlays for structures, } \\
\text { equipment, and software, net } \\
\text { lending/or net borrowing of funds. }\end{array}$ & $\begin{array}{l}\text { National aggregates in } \\
\text { NIPA with some sector } \\
\text { detail. Additional } \\
\text { detail provided by BEA } \\
\text { for FFA. Truncated } \\
\text { account shown for all } \\
\text { sectors. }\end{array}$ & $\begin{array}{l}\text { Detail for all sectors is } \\
\text { not provided. }\end{array}$ \\
\hline & Financial & $\begin{array}{l}\text { How net lending/net borrowing was } \\
\text { satisfied through increase in } \\
\text { financial assets and incurrence of } \\
\text { liabilities. }\end{array}$ & $\begin{array}{l}\text { Sector and instrument } \\
\text { detail in the FFA and } \\
\text { ITA. }\end{array}$ & $\begin{array}{l}\text { Sector boundaries in } \\
\text { FFA may not match } \\
\text { those in NIPA; some } \\
\text { differences between rest } \\
\text { of world sector in FFA } \\
\text { and ITA. }\end{array}$ \\
\hline & $\begin{array}{l}\text { Other changes } \\
\text { in volume }\end{array}$ & $\begin{array}{l}\text { Changes in net worth that arise from } \\
\text { factors unrelated to revaluation and } \\
\text { net saving, such as bad debts, } \\
\text { accounting changes, data } \\
\text { discontinuities. }\end{array}$ & $\begin{array}{l}\text { Some sector and } \\
\text { instrument detail in } \\
\text { FFA and ITA. }\end{array}$ & $\begin{array}{l}\text { Not provided for all } \\
\text { sectors. More limited } \\
\text { than the revaluation } \\
\text { account. }\end{array}$ \\
\hline & Revaluation & $\begin{array}{l}\text { Nominal changes in net worth } \\
\text { arising from holding gains/losses. } \\
\text { Splits gains/losses into real and } \\
\text { relative price changes }\end{array}$ & $\begin{array}{l}\text { Some sector and } \\
\text { instrument detail in } \\
\text { FFA and ITA. }\end{array}$ & $\begin{array}{l}\text { Not provided for all } \\
\text { sectors. In FFA, } \\
\text { limited to equity shares } \\
\text { and real estate. }\end{array}$ \\
\hline \multirow{3}{*}{ Balance sheet } & $\begin{array}{l}\text { Opening } \\
\text { position }\end{array}$ & $\begin{array}{l}\text { Beginning period value of assets, } \\
\text { liabilities, and net worth. }\end{array}$ & $\begin{array}{l}\text { Published for some } \\
\text { sectors in the FFA. }\end{array}$ & $\begin{array}{l}\text { Not provided for all } \\
\text { sectors. }\end{array}$ \\
\hline & $\begin{array}{l}\text { Changes in } \\
\text { stock positions }\end{array}$ & $\begin{array}{l}\text { Summary of changes in net worth } \\
\text { due to (a) capital formation, (b) net } \\
\text { lending/borrowing, (c) revaluation } \\
\text { of assets and liabilities, and (d) } \\
\text { other changes in volume. }\end{array}$ & $\begin{array}{l}\text { Published for some } \\
\text { sectors in the FFA, but } \\
\text { not in the form } \\
\text { envisioned in the SNA. }\end{array}$ & $\begin{array}{l}\text { A change in format } \\
\text { might be helpful, using } \\
\text { international } \\
\text { terminology. }\end{array}$ \\
\hline & $\begin{array}{l}\text { Closing } \\
\text { position }\end{array}$ & $\begin{array}{l}\text { Ending period value of assets, } \\
\text { liabilities, and net worth. }\end{array}$ & $\begin{array}{l}\text { Published for some } \\
\text { sectors in the FFA. }\end{array}$ & $\begin{array}{l}\text { Not provided for all } \\
\text { sectors. }\end{array}$ \\
\hline
\end{tabular}


There are several differences between draft SNA-USA sectors and those in SNA93 and current publications.

- The household sector includes nonprofit institutions serving households

(NPISH). Over the past decade, both agencies developed and published separate sets of estimates for NPISHs, but their definitions of the sector boundary differ enough at this time that combining separately estimated financial and nonfinancial flows was not possible. In addition, assets of bank personal trusts are part of assets of the household sector in draft SNA-USA; in the FFA, such trusts are a separate financial sector, with the level and change in the total value of the sector assets a separate instrument held by households.

- The division of the nonfinancial business sector in draft SNA-USA into corporate and noncorporate sectors closely matches current publications. ${ }^{11}$ The noncorporate sector includes both partnerships and sole proprietors, the latter of which would be within the household sector boundary in SNA93, while the former would be merged with corporations. ${ }^{12}$

- Draft SNA-USA treatment of housing, specifically owner-occupied and tenantoccupied housing, differs in some respects from SNA93 guidance, but is the same as in the NIPA and FFA. Owner-occupied housing production and finances are in the household sector, and the transactions associated with such activity are treated as business-type transactions within the sector. Rental housing transactions are also of a business type, but they are part of the nonfinancial noncorporate business sector in

\footnotetext{
${ }^{11}$ SNA93, and international statistical terminology generally, defines corporation more broadly than in the U.S. In the international terminology, a corporation sector refers to institutional business enterprises grouped together because of the type of function they perform while, in the U.S., a corporation sector refers to a legal form of business. Except in instances where the meaning should be clear or where the statistical consequences are judged insignificant, draft SNA-USA has retained the terminology in the NIPA and FFA, using business to refer to type of sector and corporation to refer to a specific legal form of business.

12 SNA93 defines quasi-corporations as unincorporated enterprises operated as if they were separate corporations whose de facto relationship to their owner is that of a corporation to its shareholders. It specifically notes one form of quasi-corporation is an unincorporated enterprise, including an unincorporated partnership, owned by households, which is operated as if it were a privately owned corporation. Quasi-corporations are not limited to those owned by households, however; they may include government business enterprises and partnerships.
} 


\begin{tabular}{|c|c|c|}
\hline \multicolumn{3}{|c|}{ TABLE B: SECTORS IN DRAFT SNA-USA } \\
\hline SECTOR & SUBSECTORS & COMMENTS \\
\hline $\begin{array}{l}\text { 1. Households and nonprofit } \\
\text { institutions serving households }\end{array}$ & None & $\begin{array}{l}\text { Current efforts seek to coordinate the NIPA and } \\
\text { FFA information for consistency in sector } \\
\text { boundary and data sources. }\end{array}$ \\
\hline \multirow[b]{2}{*}{ 2. Nonfinancial business } & Nonfinancial corporate business & \multirow{2}{*}{$\begin{array}{l}\text { In SNA93, the unincorporated business sector is } \\
\text { divided into units that are not separable from } \\
\text { households that own them (for example, most } \\
\text { sole proprietorships), which is included in the } \\
\text { household sector, and units that are distinct and } \\
\text { maintain separate accounts (for example, } \\
\text { partnerships), which are included in the } \\
\text { nonfinancial corporate business sector. At } \\
\text { present, available source data do not permit this } \\
\text { treatment for the U.S., nor is it clear that the } \\
\text { SNA93 treatment is most useful for analysis, } \\
\text { although agencies may consider this treatment, if } \\
\text { additional source data are developed. }\end{array}$} \\
\hline & $\begin{array}{l}\text { Nonfinancial noncorporate } \\
\text { business } \\
\text { (partnerships and sole } \\
\text { proprietorships) }\end{array}$ & \\
\hline 3. Financial business & None & $\begin{array}{l}\text { Financial businesses in the U.S. represent a } \\
\text { diverse set of institutions that carry out } \\
\text { intermediation of funds. Additional subsectors } \\
\text { and detail on their types of transactions are } \\
\text { provided in the FFA. Data for revaluations, other } \\
\text { changes in volume (such as for loan write-offs), } \\
\text { and value of tangible assets need to be } \\
\text { developed. }\end{array}$ \\
\hline \multirow{2}{*}{ 4. General government } & $\begin{array}{l}\text { Federal government, including } \\
\text { federal government enterprises }\end{array}$ & \multirow[t]{2}{*}{$\begin{array}{l}\text { Developing information for the market value of } \\
\text { tangible assets remains problematic, particularly } \\
\text { land or the combination of land and structures. } \\
\text { Monuments, parks, and other public facilities } \\
\text { present difficult valuation issues. }\end{array}$} \\
\hline & $\begin{array}{l}\text { State and local governments, } \\
\text { including regional government } \\
\text { enterprises }\end{array}$ & \\
\hline 5. Rest of world & None & $\begin{array}{l}\text { SNA measures an increase in purchases of } \\
\text { national securities by foreigners as an increase in } \\
\text { rest of world assets. In the balance of payments, } \\
\text { such flows are a positive capital inflow to the } \\
\text { nation. Draft SNA-USA provides an integration } \\
\text { of foreign activity with other sectors. }\end{array}$ \\
\hline
\end{tabular}


draft SNA-USA. As suggested above, SNA93 would include activities of individuals that provide rental homes in the household sector.

- Draft SNA-USA, SNA93, and NIPA differ in their placement of government enterprises, such as the Postal Service and Tennessee Valley Authority. In draft SNA-USA and the FFA, their activity is within the government sector. In the NIPA, there is a mixed treatment of government business enterprises; their activities are presented as part of the business sector in the production account; but, for calculating net saving, they are consolidated with the government sector in the government receipts and expenditures account.

In addition, as indicated in the comments in table $\mathrm{B}$, portions of the other changes in volume, revaluation, and balance sheet accounts are unavailable or underdeveloped for some sectors. In particular, balance sheet accounts for the government sectors and financial business sector reflect only the reproducible portion of tangible assets. Thus, buildings are included, but the full market value of real estate is not.

The following narrative introduces significant elements of draft SNA-USA. It also highlights differences from currently published series. After some brief comment about the total economy current account, the discussion turns to the sectors, with more detailed comments for the household sector to explain the terminology and structure common to all the tables.

\section{TOTAL ECONOMY—CURRENT ACCOUNT (TABLE 1)}

Draft SNA-USA table 1 shows the current account for the economy as a whole, and illustrates that the account reflects an income-side approach. We have used SNA93 terminology - GDP/gross value added on line 1, and net domestic product (line 3), while in the NIPA we refer to these figures as gross (net) domestic income. That is, in the NIPA, there are two methods of calculating GDP. The featured measure, known as GDP, is based on the sum of final expenditures (personal consumption, private investment, net exports, and government consumption and investment). The other measure, known as gross domestic income, is based on the sum of incomes generated from production. Because these measures, which are conceptually identical, are estimated from separate source data, they differ by a statistical discrepancy. For this paper we avoid dealing with the effects of this discrepancy by focusing on the income-side 
measure, or gross domestic income; the more familiar expenditure-side measure is shown on line $44 .^{13}$

The specific income factors are shown on lines 4 through 8 . One term, operating surplus (line 8), is a concept that only recently has appeared in U.S. accounts. In SNA93, it is defined as "the surplus accruing from processes of production before deducting any explicit or implicit interest charges, rents, or other property incomes payable on the financial assets, land, or other tangible nonproduced assets required to carry on the production." 14 In other words, it is a broad income concept that includes interest, rent, and profits.

Lines 9 and 10, of table 1, account for the difference between domestic product and national income. Specifically, they add to gross product income receipts from the rest of the world and remove income payments made to the rest of the world.

The middle section of the current account describes the factors of net national income (line 11). These include the compensation received by employees and operating surplus. Net saving for the total economy (line 41) is derived by subtracting final consumption expenditures (line 40) from disposable income (line 39). ${ }^{15}$

\section{HOUSEHOLDS AND NONPROFIT ORGANIZATIONS SERVING HOUSEHOLDS SECTOR (TABLE 3)}

Production in the household sector (Table 3, line 1) and net domestic product (line 3) are measured largely by compensation paid (line 4) and net operating surplus in draft SNA-USA (line 8). In the context of the household sector, the operating surplus is that part of GDP associated with owner-occupied housing. It also includes net interest on fixed assets used by NPISHs. In both cases, the operating surplus is net of taxes on production and imports less subsidies (line 7).

While output of the sector is relatively small, it receives the bulk of net national income (line 9) in the form of employee compensation (line 11) and property income (line 14), including "withdrawals from income of quasi-corporations (line 18)," which is the sum of proprietors' income and rental income of tenant-occupied housing in the NIPA.

\footnotetext{
${ }^{13}$ Total gross value added NIPA table 1.3.5 (Gross Value Added by Sector) is similar but not identical to the draft SNA-USA gross value added. The NIPA table subsumes the statistical discrepancy and puts value added of government enterprises in the business sector; draft SNA-USA has not allocated the discrepancy, and government enterprises are in the government sector.

${ }^{14}$ SNA93 97.82

${ }^{15}$ Draft SNA-USA Table 2, "Selected Aggregates for Total Economy and Sectors," is an example of the supplementary information that can be provided in a full set of accounts. It summarizes the contribution of sectors for several important aggregates. Table 2 was produced mainly as a way to check the consistency of our compilations of sectors with published aggregates. However, it appeared to be of interest on its own and is offered in the overall set of draft SNA-USA tables.
} 
In draft SNA-USA, household sector disposable income (line 26) is slightly different from "disposable personal income" in the NIPA. In draft SNA-USA, interest received (line 15) and interest paid (line 19) are part of the derivation of net national income for the sector. In addition, current transfers paid (line 25) are subtracted from net national income. In the NIPA, disposable personal income includes interest paid and other current transfers paid.

Net saving (line 28) in draft SNA-USA differs from that in the NIPA by the amount of wage accruals less disbursements, which are included in compensation received by the household sector in draft SNA-USA. In addition, in draft SNA-USA, net saving is calculated as disposable income (line 26) less sector consumption expenditures (line 27), instead of the more comprehensive personal outlays concept in the NIPA. When calculating the household sector saving rate, the smaller denominator in draft SNA-USA and difference in the level of net saving results in a slightly higher level for the rate (Chart 1, panel A).

The capital account for the household sector is straightforward. Net saving is reduced by capital transfers (net) (line 31). For this sector, such transfers are negative, on net, reflecting estate and gift taxes paid to the government and net migrants' transfers received by the rest of the world.

Importantly, net capital formation (line 32) excludes consumer durable goods purchases, which are a component of consumption expenditures (line 27). The accounting treatment of consumer durable goods outlays in the current and capital account is consistent with SNA93 (and NIPA). ${ }^{16}$ However, because we chose to show the value of the stock of consumer durable goods as household sector assets, this treatment has implications for the revaluation and balance sheet accounts.

The difference between saving and capital formation is net lending or borrowing (line 37), the amount the sector supplies to financial markets for other sectors or requires from the financial markets to meet its own needs. The figures in table 3 indicate the household sector has been a net borrower since 1997.

The details of how the sector meets its borrowing requirement is revealed in the financial account, where accounting identities require net lending/net borrowing to equal the net acquisition of financial assets (line 39) less the net incurrence of liabilities (line 68). The "net" in the financial account refers to purchases less sales of assets, and the extensions less repayment of liabilities.

\footnotetext{
${ }^{16}$ See also Barbara M. Fraumeni and Sumiye Okubo, "Alternative Treatments of Consumer Durables in the National Accounts," paper prepared for the BEA Advisory Committee Meeting, May 11, 2001.
} 
Although conceptually the same, the value of household sector net lending/net borrowing derived in the financial account (line 79) differs substantially from that in the capital account. Indeed, it is less clear from the figures on line 79 whether the sector has consistently borrowed over the past six years.

The difference between the net lending/net borrowing derived in the capital account and that derived in the financial account is defined in draft SNA-USA as the sector's statistical discrepancy (line 83). The treatment of the statistical discrepancy is problematic and has implications for the estimates of household sector net worth.

Some nations do not show a discrepancy between the two measures of net lending/net borrowing. Rather, they force equality in some way, such as splitting the difference between the financial account and the current and capital accounts. (There is no recognition of such discrepancies in SNA93.) Our practice is to report the discrepancy as a component of the "other changes volume account." An indication, albeit a crude indication, of the success of our efforts to bring the accounts into better alignment in the future will be the reduction of the statistical discrepancies between the financial account and the current and capital accounts for sectors. ${ }^{17}$ We examine the alternative values of net lending/net borrowing derived in each sector in the next section.

The remaining accumulation accounts provide additional information on how estimates of net worth of the sector are affected in the period. The account for "other changes in volume" allows for recording factors that are not defined as financial transactions or holding gains and losses in the period, such as the statistical discrepancy noted above. The revaluation account lists changes in value of assets due to holding gains and losses.

We used the other changes in volume account to insert net investment in consumer durable goods (line 81). Our view, not shared in SNA93, is that the value of such goods is an important household sector asset that belongs with other tangible assets on the balance sheet account. BEA estimates the value of the stock consistent with the expenditures in the current account, including depreciation and revaluations. The FRB uses the data to complete estimates of tangible assets in the FFA sector balance sheet statement. Draft SNA-USA retains that balance sheet treatment.

The revaluation account (lines 84 to 94) records nominal holding gains and losses for nonfinancial assets and financial assets. We have carried over the practice of estimating the gains for real estate (combined land and structures), because the agencies have found no acceptable

\footnotetext{
${ }^{17}$ In the household sector, the sum of net lending/net borrowing in the financial account and net capital
} formation is an alternative, but conceptually equivalent, measure of saving from the FFA. 
way, on a macro-sector basis, to separate changes in the value of land from changes in the value of structures on the land. ${ }^{18}$

The change in net worth for the household sector is shown on line 95 at the beginning of the balance sheet account. It is the sum of net capital formation, net lending/net borrowing, other changes in volume, and nominal holding gains/losses. The change in net worth is the same as that published in the FFA, but the components differ. The net lending/net borrowing figure used for calculation of net worth is that from the capital account, rather than the financial account. The statistical discrepancy between the financial and capital account enters into the other changes in volume account. The change in net worth as a percent of disposable income differs slightly from that currently published only because the denominator (disposable income) in draft SNA-USA is different (Chart 1, panel B).]

End of period stocks in the household balance sheet are similar to those published in the FFA, although the terminology for asset and liability items is consistent with international terminology, which should allow for easier comparison across countries. Instruments have been grouped as recommended in SNA93. This was also done in the financial account in draft SNA-USA.

\section{NONFINANCIAL NONCORPORATE BUSINESS SECTOR (TABLE 4)}

As noted above, the nonfinancial noncorporate business sector includes partnerships and sole proprietorships (including tenant-occupied housing). Draft SNA-USA has a full set of accounts for this sector.

Income generated in the sector is paid out to the household sector as withdrawals from income of quasi-corporations (Table 4, line 14). ${ }^{19}$ As a result, the sector has no net saving. Nonetheless, there is capital formation and financial transactions in the noncorporate business sector. The additions to net worth (line 71) result mainly from capital gains on real estate shown in the revaluation account (line 63). ${ }^{20}$

\footnotetext{
${ }^{18}$ No attempt was made to separate nominal holding gains into neutral gains (those due to changes in the general price level) and real gains (those due to changes in the relative prices of assets), as SNA93 would dictate.

${ }^{19}$ Households withdraw income from both financial and nonfinancial quasi-corporations.

${ }^{20}$ We considered a number of ways to treat household equity in nonfinancial noncorporate business, and, although the method chosen is consistent within the sequence of accounts, it is not necessarily consistent with SNA93 and is under review.
} 


\section{NONFINANCIAL CORPORATE BUSINESS SECTOR (Table 5)}

We have been able to provide a full set of accounts for the nonfinancial corporate business sector. The sector's value added (Table 5, line 1) is more than half of total output of the economy. Consumption of fixed capital (line 2) in this sector, as with other sectors, is on an economic basis, reflecting the capital consumption adjustment to book (tax) depreciation. Similarly, in the capital account, inventory investment (line 32) reflects the NIPA valuation adjustment so that inventories are at current prices and on a consistent accounting basis.

The draft SNA-USA current account arguably offers a more comprehensive and intuitive view of flows through the sector, although the terminology is probably unfamiliar to users of NIPA tables. Measures of profits and cash flow are noticeably missing from our presentation. Given their importance for analytical work in the U.S., providing them likely would be a welcome addition to future versions.

The sector has no final consumption expenditures, and the SNA format shows disposable income (line 23) as net saving (line 24); net saving in this sector and the financial business sector is the same as undistributed corporate profits in the NIPA. Again, the presentation lacks a measure of total internal funds that is used to derive the financing gap shown in the FFAsometimes-helpful measure of the impetus for corporate borrowing. Net lending/net borrowing (line 33) is nearly the same concept, but it includes undistributed profits of foreign subsidiaries, which are not in the FFA calculation.

The statistical discrepancy resulting from the difference in net lending/net borrowing in the capital account and in the financial account was handled the same way as it was for the household sector. Net saving in the capital account was used to derive changes in net worth (line 93), and the discrepancy is reported in the other changes in volume account (line 80).

The calculation and interpretation of net worth in the nonfinancial corporate business sector (line 144) is substantially different from that currently published. In the FFA, net worth is the market (or replacement) value of assets less liabilities, excluding equity capital. That measure of net worth is sometimes compared to the market value of shares for nonfinancial corporate businesses or to net worth derived with tangible assets at historical cost. Draft SNA-USA follows the format in SNA93, which calculates net worth as the market (or replacement) value of assets less liabilities, including the market value of shares and other equity (line 136).

The currently published measure of net worth has been a large positive figure that has risen from just over $\$ 4$ trillion in 1985 to about $\$ 9-1 / 2$ trillion in 2002 (Chart 2, panel A). In contrast, nonfinancial corporate business sector net worth in draft SNA-USA has both positive and negative values (panel B). Indeed, as would be expected from the elevated equity valuations 
in the late 1990s, the draft SNA-USA measure of net worth moved down sharply over the 1990s to \$-7 trillion before turning up in 2000 and becoming positive in 2002 .

The draft SNA-USA measure of net worth may be interpreted as a variant of Tobin's Q. As defined by Tobin, $Q$ is the ratio of the market value of the firm (equity plus debt) to the replacement cost of its tangible assets. For the nonfinancial corporate business sector, debt and equity are the bulk of liabilities in the SNA format, and they correspond to the numerator of Q. Tangible assets (the denominator in Q) are about half of total assets on the sector balance sheet. ${ }^{21}$ Therefore, a negative net worth in draft SNA-USA corresponds to a Q greater than one, while a positive net worth corresponds to a $\mathrm{Q}$ of less than one.

\section{FINANCIAL BUSINESS SECTOR (TABLE 6)}

The financial business sector includes the monetary authority, depository institutions, insurance and pension funds, and all other financial intermediaries, such as finance companies, mutual funds, and brokers and dealers. But for a complete accounting for the value of real estate, we have been able to compile nearly a full set of accounts for the combined sector.

The current account and capital account are structured the same as the nonfinancial corporate business sector, with the exception of withdrawals from quasi-corporations, and the financial account is a summation of lending and borrowing flows of all the financial intermediaries in the flow of funds accounts. For this sector, we did not net intra-sector assets and liabilities. For example, issuance of a mortgage-backed security by a government sponsored enterprise and purchased by a bank is reflected as a net incurrence of a liability (included in line 50 of Table 6,) and as an acquisition of a financial asset (included in line 33).

A consequence of showing gross flows of the sector is that there are sizable revaluations of financial assets (line 74) and liabilities (line 78). As with other sector accounts, shares and other equity instruments were revalued for capital gains and losses. Other types of liabilities, such as bonds and mortgages were not revalued. Past efforts by staff at the Federal Reserve Board found little impact on net worth of sector balance sheets when liabilities other than equities were revalued. However, that work predated the recent down-shift in interest rates; and it was not applied to the financial business sector as defined in draft SNA-USA.

While draft SNA-USA shows an account for other changes in volume for financial corporations, the data are not well developed. In particular, debt write-offs are not included.

\footnotetext{
${ }^{21}$ The popular press often uses a variant of $Q$ equal to the ratio of the market value of equity of the sector to the published net worth of the sector. The popular version differs from true $\mathrm{Q}$ by including financial assets and non-debt liabilities in the denominator.
} 
Rather they are reflected in changes in the flows in the financial account. A better articulation of such information would likely make analysis of business and household financing in the economy clearer, and the draft SNA-USA format provides a focused means for eventually recording the figures as they are developed.

The change in net worth for the financial business sector (and for the government sectors that follow) is calculated using the same factors as for the household and nonfinancial business sectors, with an important exception. Data are available only for reproducible assets, which include structures; data are not available for the market value of real estate, which combines the value of structure and land. As a result, the change in net worth (line 85) and the level of net worth (line 134) are limited. The change excludes revaluations of real estate and the level excludes the market value of real estate, but includes the current cost value of structures.

\section{GOVERNMENT SECTORS (TABLES 7 AND 8)}

In the government sectors, current surpluses (deficits) are measured by net saving (line 24 of both tables 7 and 8). Net lending or borrowing (line 32) in the capital account provides a broader measure of the surplus/deficit, by taking into account investment in fixed assets; it is the measure most akin to the budget surplus/deficit reported by U.S. Office of Management and Budget (OMB).

The capital account also shows the net acquisition of nonproduced nonfinancial assets (line 31 in both tables). The federal government has been a seller of such assets, which include the sale of electromagnetic spectrum rights and leasing of offshore drilling rights. For state and local governments, acquisition of nonproduced assets reflects net purchases of land and access rights for roads. The counterparty for the government sales, leases, and purchases is the nonfinancial corporate business sector.

The revaluation and balance sheet account for the government sectors is limited by the lack of information for real estate values, the same, as is the case for the financial businesses sector. Estimates for real estate — actually for structures and land — are available in supplementary information in the federal government budget documents produced each year by OMB. ${ }^{22}$ However, as noted by OMB, the data are somewhat rough and are provided for illustrative purposes in showing how a national balance sheet could be constructed; they have not been fully vetted by the agencies for use in national accounts. Moreover, there are no estimates

\footnotetext{
${ }^{22}$ Analytical Perspective, Budget of the United States Government, Fiscal Year 2005, Part IIthe Federal Government's Assets and Liabilities, (Office of Management and Budget, Washington, D.C. 2004), 187-190.
} 
for state and local governments. As a result, stocks in the balance sheet in draft SNA-USA are for reproducible tangible assets, financial assets, and liabilities.

In the past, BEA and the FRB have collaborated to compile a consolidated government sector. Both the NIPA and FFA have a consolidated sector and doing so in SNA format should be a relatively straightforward exercise for the agencies in the future.

\section{REST OF WORLD SECTOR (TABLE 9)}

The rest of world sector is a mirror image of the international transactions accounts published by BEA. In the current account, net saving, or the current external balance (Table 9, line 8), is derived as the difference in foreign income received from U.S. residents and foreign outlays to U.S. residents. The capital account adds net capital transfers and subtracts acquisitions of nonproduced nonfinancial assets to derive net lending and borrowing to U.S. residents from the rest of the world. That figure must offset the sum of net lending/net borrowing for domestic sectors. $^{23}$

Data for the draft SNA-USA financial, other changes in volume, and revaluation accounts are taken from BEA's international transaction accounts and underlying source data. The nature of the presentation is the same as the domestic sectors. It differs from the ITA, however, because many financial transactions are netted in draft SNA-USA (and the FFA), while they are shown gross in the ITA.

The statistical discrepancy in the rest of world sector - the difference between net lending calculated in the current and capital account and net lending in the financial account reflects the statistical discrepancy in the recorded balance of payments as well as a combination of other differences in residency definitions in the NIPA, ITA, and the FFA. The agencies have a project underway to reconcile differences between the accounts.

\section{ISSUES CONCERNING THE INTEGRATION OF THE ACCOUNTS}

As noted above, the agencies are working to minimize sector discrepancies that result from using alternative data sources and methods. Those discrepancies are summarized by the net lending/net borrowing measures compared in the panels of Chart 3. The charts indicate that the pattern of net lending/net borrowing is similar in each sector whether measured by the capital

\footnotetext{
${ }^{23}$ Net lending from the rest of the world does in fact equal the net borrowing from the domestic sectors after accounting for the NIPA statistical discrepancy, wage accruals less disbursements, and rounding differences. The statistical discrepancy is a factor because we used data for capital formation from the NIPA product side and net saving from the NIPA income side. The figures for all the sectors are shown on draft SNA-USA table 2.
} 
account or the financial account. Even so, there are significant differences for some sectors and in some years.

For the household sector (Chart 3, panel A), the differences in net lending/net borrowing between draft SNA-USA capital account and financial account are significant, but relatively stable in sign for the earlier period shown. Until about 1998, net lending derived in the financial account averaged about two percentage points (of disposable income) more than in the current account. In recent years, the differences have narrowed on average. Put another way, the financial account implies that households accumulated more assets than suggested by flows from the capital account, and household sector net worth is about six percent higher than would be the case without the discrepancy that is included in the changes in other volume account. (The six percent represents the value of the discrepancy accumulated over time.)

The household sector discrepancy in the FFA has been the subject of several studies over the years. ${ }^{24}$ The residual calculation of some categories in the current account and the residual calculation of most asset categories and some liability categories in the financial and balance sheet accounts leave considerable room for speculation on the sources of the difference. A benefit of integrating the national accounts as we have done for this paper is that the nature of the problem is more clearly defined in terms of stocks and flows of the sector.

An additional concern to the agencies has been the difference in net lending/net borrowing for the nonfinancial corporate business sector (panel B of Chart 3). Creating draft SNA-USA pointed to several likely sources for the discrepancy. A particularly vexing one lies in the agencies separation of nonfinancial and financial businesses, a boundary that is important for analysis of disintermediation and evaluation of flows, such as interest paid and interest received. The boundary also has implications for measuring stocks and net worth in the sectors.

The business boundary problem reflects in part differences in source data for the NIPA and the FFA. NIPA relies heavily on tax return data, and the FFA supplements tax data with surveys and regulatory information to compile accounts for financial corporations. In the NIPA, corporations that file consolidated returns, which combine data for nonfinancial and financial subsidiaries, are either in the financial or nonfinancial business sectors, depending on the predominant business. In the financial accounts, adjustments are made with the supplementary information to split consolidated corporations into financial and nonfinancial enterprises. The

${ }^{24}$ See for example, "Measuring Household Saving: Recent Experience from the Flow-of-Funds Perspective," John F. Wilson, James L. Freund, Frederick O. Yohn, Jr., and Walter Lederer, in THE MEASUREMENT OF SAVING, InVESTMENT, AND WEALth, Robert E. Lipsey and Helen Stone Tice, editors, (Studies in Income and Wealth, Volume 52, 1989), 101-152. 
issue is particularly acute in cases for firms with captive finance companies, such as General Motor's GMAC and General Electric's GE Capital.

Some encouragement that solving the boundary problem will reduce the discrepancy is evident on Chart 4. The net lending/net borrowing estimates of the two sectors combined aligns somewhat better than for the sectors separately.

In addition to the boundary problem, part of the difference between net lending/net borrowing measures in the nonfinancial corporate business sector likely reflects the booking of miscellaneous financial assets. In the financial accounts, changes to goodwill and other intangible assets are included in flows of miscellaneous financial assets. Such flows are large and positive during periods of heavy merger activity; they are large and negative during periods of economic weakness. The impact of changes in such assets is not reflected in the current and capital accounts. SNA93 standards would relegate a portion of the changes in the value of such assets to the other changes in volume account. An effort to reclassify them into revaluations and/or other changes in volume is likely to have a sizable impact on the statistical discrepancy. No changes were made for draft SNA-USA for the business sectors' boundary or other accounting issues.

Finally, net lending/net borrowing estimates for the federal government sector (panel C of Chart 3) are close, reflecting a generally high quality of information available and recent efforts by the agencies to ensure consistent use of that data. In contrast, net lending/net borrowing estimates for the state and local government sector (panel D), where the data tend to be of lower quality, diverge by significant amounts. It would appear that coordination of estimation methods for missing data would more tightly integrate the accounts of the state and local government sector.

\section{WhERE Do We Go From Here?}

Aside from reformulating the structure of the accounts to international standards, it has been our intention to use the integration of the accounts to improve the quality and usefulness of the estimates published. Specific items that require joint work by the agencies have been identified, including further work on ensuring that sector boundaries are consistent across accounts, developing additional source material for sectors where information is not available, and sharing data sources and methods for estimating missing data.

We have shown that SNA-USA tables can be produced for the period 1985-2002. Considerable work is still required, if the agencies chose to rework the published figures into the draft SNA-USA structure for the period before 1985. The exercise indicated, moreover, that 
considerable investment is needed to produce the integrated accounts on a continuing basis, and even greater investment to carry out the improvements identified.

BEA's Strategic Plan outlines a number of research and development activities related to the development of integrated accounts. Work is already under way to examine sector definitions, with particular consideration given to the development of improved source data on government business enterprises. Other research is also being conducted on improving the consistency of source data between the NIPA and FFA, for example, to improve consistency of NIPA interest flow estimates with FFA estimates of interest-bearing assets and liabilities. Efforts are also underway to improve the estimates of fixed assets and to provide more reliable information on valuation and legal form of ownership of these assets. Finally, efforts are also underway, as described in other papers presented at this conference, to improve integration with other BEA accounts, such as the input-output accounts, and with the BLS productivity statistics.

In addition to the joint staff work noted above, efforts at the Federal Reserve are directed toward improving integration in the capital accounts, especially expanding the detail for financial sectors. In conjunction with that work will be an effort to develop detailed information for the other changes in volume accounts, especially data for debt write-downs.

An important and useful result of integrated macroeconomic accounts would be an ability to produce on a regular basis a national balance sheet. Several deficiencies, some already noted, would need to be resolved before such a balance sheet is completed. Three of the most important are:

- Further development of the other changes in volume and revaluation accounts. Although the other changes in volume accounts in draft SNA-USA is more advanced than found in other countries' publications, they are still limited. The effort to expand the accounts would require a closer review of the accounting techniques used in data sources and whether those techniques align with what is needed for macroeconomic accounts so that differences in flows, revaluations, and other changes in volume can be separated.

- Improved data for real estate values in some sectors, especially for the government sector and techniques for separating the market value of land and structures.

- Removal or reconciliation of remaining differences between the current and accumulation accounts and the international transactions accounts. 


\section{BIBLIOGRAPHY}

1. Bloem, Adriann M., Robert J. Dipplesman, and Nils Ø. Mæhle, QuARTERLY National AcCounTS MANUAL, CONCEPTS, DATA SOURCES, AND COMPILATION, International Monetary Fund, (Washington, D.C., 2001).

2. Bureau of Economic Analysis, "BEA's Strategic Plan for FY 2001-2005," SURVEY OF CURRENT BUSINESS, vol. 82 (May 2002), 8-32.

3. Commission of the European Communities-Eurostat, International Monetary Fund, Organization for Economic Co-operation and Development, United Nations, and World Bank, SYSTEM OF NATIONAL ACCOUNTS 1993, prepared under the auspices of the Inter-Secretariat Working Group on National Accounts, 1993.

4. Fraumeni, Barbara M., and Sumiye Okubo, "Alternative Treatments of Consumer Durables in the National Accounts," paper prepared for the BEA Advisory Committee Meeting, May 11, 2001.

5. International Monetary Fund, BALANCE OF PAYMents ComPILATION Guide, (Washington, D.C., 1995).

6. International Monetary Fund, Monetary and Financial Statistics Manual, (Washington, D.C., 2000).

7. Lal, Kishori, "Measurement of Output, Value Added, GDP in Canada and the United States: Similarities and Differences," Research paper 13F0031MIE-No.010, Statistics Canada (June 2003).

8. Mayerhauser, Nicole, Shelly Smith, and David F. Sullivan, "Preview of the 2003 Comprehensive Revision of the National Income and Product Accounts: New and Redesigned Tables," SURVEY OF CURRENT BusinesS, vol. 83 (August 2003), 7-31.

9. Moulton, Brent R. and Eugene P. Seskin, "Preview of the 2003 Comprehensive Revision of the National Income and Product Accounts: Changes in Definitions and Classifications," SURVEY OF CURRENT BUSINESS, vol. 83 (June 2003), 17-34.

10. Ruggles, Richard and Nancy D. Ruggles, "Integrated Economic Accounts for the United States, 194780,” SURVEY OF CURRENT BUSINESS, vol. 62 (May 1982), 1-53.

11. Wilson, Karen, "The Architecture of the System of National Accounts: A Three-Way International Comparison of Canada, Australia, and the United Kingdom," prepared for Conference on Research in Income and Wealth, Architecture of National Accounts (April 16-17, 2004, Washington, D.C.).

12. Wilson, John F., James L. Freund, Frederick O. Yohn, Jr., and Walter Lederer, "Measuring Household Saving: Recent Experience from the Flow-of-Funds Perspective," in The MEasurement OF SAVInG, InVESTMENT, AND WEALTH, Robert E. Lipsey and Helen Stone Tice, editors, National Bureau of Economic Research, Studies in Income and Wealth, Volume 52, 1989, 101-152.

13. U. S. Office of Management and Budget, Analytical Perspective, Budget of the United States GOVERnMENT, Fiscal Year 2005, Part II-the Federal Government's Assets and Liabilities, (Washington, D.C., 2004), 187-190. 


\title{
1. Total Economy - Current Account
}

\author{
Billions of dollars
}

\begin{tabular}{|c|c|c|c|c|c|c|c|c|c|c|}
\hline & & 1995 & 1996 & 1997 & 1998 & 1999 & 2000 & 2001 & 2002 & \\
\hline 1 & $\begin{array}{l}\text { Gross domestic product(GDP)/Gross value added } \\
\text { (income approach) }\end{array}$ & 7296.4 & 7723.1 & 8233.6 & 8761.7 & 9304.2 & 9944.1 & 10213.0 & 10558.0 & 1 \\
\hline 2 & Less consumption of fixed capital & 878.4 & 918.0 & 974.4 & 1030.1 & 1101.2 & 1187.8 & 1266.9 & 1288.6 & 2 \\
\hline 3 & Equals net domestic product/Net value added & 6418.1 & 6805.0 & 7259.2 & 7731.6 & 8202.9 & 8756.3 & 8946.2 & 9269.3 & 3 \\
\hline 4 & Compensation of employees (paid) & 4197.3 & 4394.7 & 4666.0 & 5023.9 & 5362.3 & 5787.3 & 5945.4 & 6024.4 & 4 \\
\hline 5 & Wages and salaries & 3439.7 & 3627.3 & 3879.1 & 4187.3 & 4476.6 & 4833.8 & 4947.9 & 4979.8 & 5 \\
\hline 6 & Employers' social contributions & 757.6 & 767.4 & 787.1 & 836.7 & 885.7 & 953.5 & 997.7 & 1044.6 & 6 \\
\hline 7 & Taxes on production and imports less subsidies & 524.2 & 546.8 & 579.1 & 604.5 & 629.9 & 664.5 & 674.6 & 721.8 & 7 \\
\hline 8 & Operating surplus, net & 1696.4 & 1863.5 & 2014.1 & 2103.1 & 2210.7 & 2304.5 & 2326.2 & 2523.2 & 8 \\
\hline 9 & Plus income receipts from the rest of the world & 234.0 & 248.7 & 286.7 & 287.1 & 320.8 & 382.7 & 319.0 & 299.1 & 9 \\
\hline 10 & Less income payments from the rest of the world & 198.2 & 213.7 & 253.7 & 265.8 & 287.1 & 343.7 & 283.8 & 277.7 & 10 \\
\hline 11 & Equals net national income/Balance of primary incomes, net & 6454.0 & 6840.0 & 7292.2 & 7752.9 & 8236.5 & 8795.1 & 8981.1 & 9290.8 & 11 \\
\hline 12 & Operating surplus, net & 1696.4 & 1863.5 & 2014.1 & 2103.1 & 2210.7 & 2304.5 & 2326.2 & 2523.2 & 12 \\
\hline 13 & Compensation of employees (received) & 4193.3 & 4390.5 & 4661.7 & 5019.4 & 5357.1 & 5782.7 & 5940.4 & 6019.1 & 13 \\
\hline 14 & Wages and salaries & 3435.7 & 3623.2 & 3874.7 & 4182.7 & 4471.4 & 4829.2 & 4942.9 & 4974.6 & 14 \\
\hline 15 & Employers' social contributions & 757.7 & 767.3 & 787.0 & 836.7 & 885.7 & 953.4 & 997.6 & 1044.5 & 15 \\
\hline 16 & Taxes on production and imports, receivable & 558.3 & 581.1 & 612.0 & 639.9 & 674.1 & 708.9 & 729.8 & 760.1 & 16 \\
\hline 17 & Subsidies, payable & -34.0 & -34.3 & -32.8 & -35.4 & -44.2 & -44.3 & -55.3 & -38.2 & 17 \\
\hline 18 & Property income (received) & 2892.8 & 3107.0 & 3379.3 & 3620.3 & 3787.3 & 4302.6 & 4274.8 & 4146.6 & 18 \\
\hline 19 & Interest & 1935.0 & 2030.8 & 2208.0 & 2390.2 & 2491.8 & 2877.1 & 2833.0 & 2643.0 & 19 \\
\hline 20 & Distributed income of corporations & 882.0 & 997.4 & 1086.5 & 1158.1 & 1202.8 & 1297.9 & 1331.1 & 1370.5 & 20 \\
\hline 21 & Dividends & 335.5 & 396.8 & 451.7 & 472.2 & 465.8 & 509.9 & 498.5 & 509.1 & 21 \\
\hline 22 & Withdrawals from income of quasi-corporations & 546.5 & 600.6 & 634.8 & 685.9 & 737.0 & 788.0 & 832.6 & 861.4 & 22 \\
\hline 23 & Reinvested earnings on foreign direct investment & 68.8 & 70.3 & 75.5 & 63.6 & 84.1 & 116.2 & 97.3 & 121.0 & 23 \\
\hline 24 & Rents & 7.0 & 8.6 & 9.3 & 8.4 & 8.6 & 11.4 & 13.5 & 12.1 & 24 \\
\hline 25 & Less uses of property income (paid) & 2852.9 & 3067.8 & 3342.0 & 3594.4 & 3748.4 & 4259.2 & 4234.7 & 4119.9 & 25 \\
\hline 26 & Interest & 1987.8 & 2093.5 & 2281.7 & 2467.3 & 2574.3 & 2979.3 & 2954.2 & 2769.6 & 26 \\
\hline 27 & Distributed income of corporations & 849.4 & 957.0 & 1035.9 & 1115.7 & 1161.1 & 1268.5 & 1295.9 & 1331.3 & 27 \\
\hline 28 & Dividends & 302.9 & 356.4 & 401.1 & 429.8 & 424.1 & 480.4 & 463.3 & 469.8 & 28 \\
\hline 29 & Withdrawals from income of quasi-corporations & 546.5 & 600.6 & 634.8 & 685.9 & 737.0 & 788.1 & 832.6 & 861.5 & 29 \\
\hline 30 & Reinvested earnings on foreign direct investment & 8.7 & 8.7 & 15.2 & 3.0 & 4.4 & 0 & -28.9 & 6.9 & 30 \\
\hline 31 & Rents & 7.0 & 8.6 & 9.2 & 8.4 & 8.6 & 11.4 & 13.5 & 12.1 & 31 \\
\hline 32 & Net national income/Balance of primary incomes, net & 6454.0 & 6840.0 & 7292.2 & 7752.9 & 8236.5 & 8795.1 & 8981.1 & 9290.8 & 32 \\
\hline 33 & Plus current taxes on income, wealth, etc. (received) & 959.0 & 1060.9 & 1168.5 & 1271.9 & 1362.2 & 1498.0 & 1442.8 & 1246.1 & 33 \\
\hline 34 & Less current taxes on income, wealth, etc. (paid) & 962.7 & 1063.8 & 1172.4 & 1275.3 & 1366.1 & 1500.8 & 1444.8 & 1248.1 & 34 \\
\hline 35 & Plus social benefits (received) & 1391.2 & 1457.4 & 1519.0 & 1576.8 & 1649.4 & 1744.3 & 1871.2 & 1999.7 & 35 \\
\hline 36 & Less social contributions (paid) & 1393.1 & 1459.5 & 1521.1 & 1579.2 & 1651.8 & 1746.9 & 1873.8 & 2002.6 & 36 \\
\hline 37 & Plus other current transfers (received) & 262.2 & 280.1 & 285.9 & 314.3 & 347.6 & 383.5 & 428.1 & 452.6 & 37 \\
\hline 38 & Less other current transfers (paid) & 292.1 & 314.1 & 321.6 & 357.4 & 388.4 & 434.1 & 470.5 & 507.2 & 38 \\
\hline 39 & Equals disposable income, net & 6418.5 & 6800.9 & 7250.6 & 7703.9 & 8189.2 & 8739.1 & 8934.1 & 9231.5 & 39 \\
\hline 40 & Less final consumption expenditures & 6112.4 & 6427.9 & 6764.0 & 7135.5 & 7616.5 & 8156.5 & 8543.2 & 8980.7 & 40 \\
\hline \multirow[t]{2}{*}{41} & Equals net saving & 306.1 & 373.0 & 486.6 & 568.5 & 572.7 & 582.7 & 390.9 & 250.8 & 41 \\
\hline & \multicolumn{10}{|l|}{ Memo: } \\
\hline 42 & GDP (line 1) & 7296.4 & 7723.1 & 8233.6 & 8761.7 & 9304.2 & 9944.1 & 10213.0 & 10558.0 & 42 \\
\hline 43 & Plus statistical discrepancy (NIPA) & 101.2 & 93.7 & 70.6 & -14.7 & -35.7 & -127.2 & -112.3 & -77.0 & 43 \\
\hline 44 & Equals GDP (NIPA, expenditure approach) & 7397.6 & 7816.8 & 8304.3 & 8747.0 & 9268.5 & 9817.0 & 10100.8 & 10480.9 & 44 \\
\hline
\end{tabular}




\section{Selected Aggregates for Total Economy and Sectors}

Billions of dollars

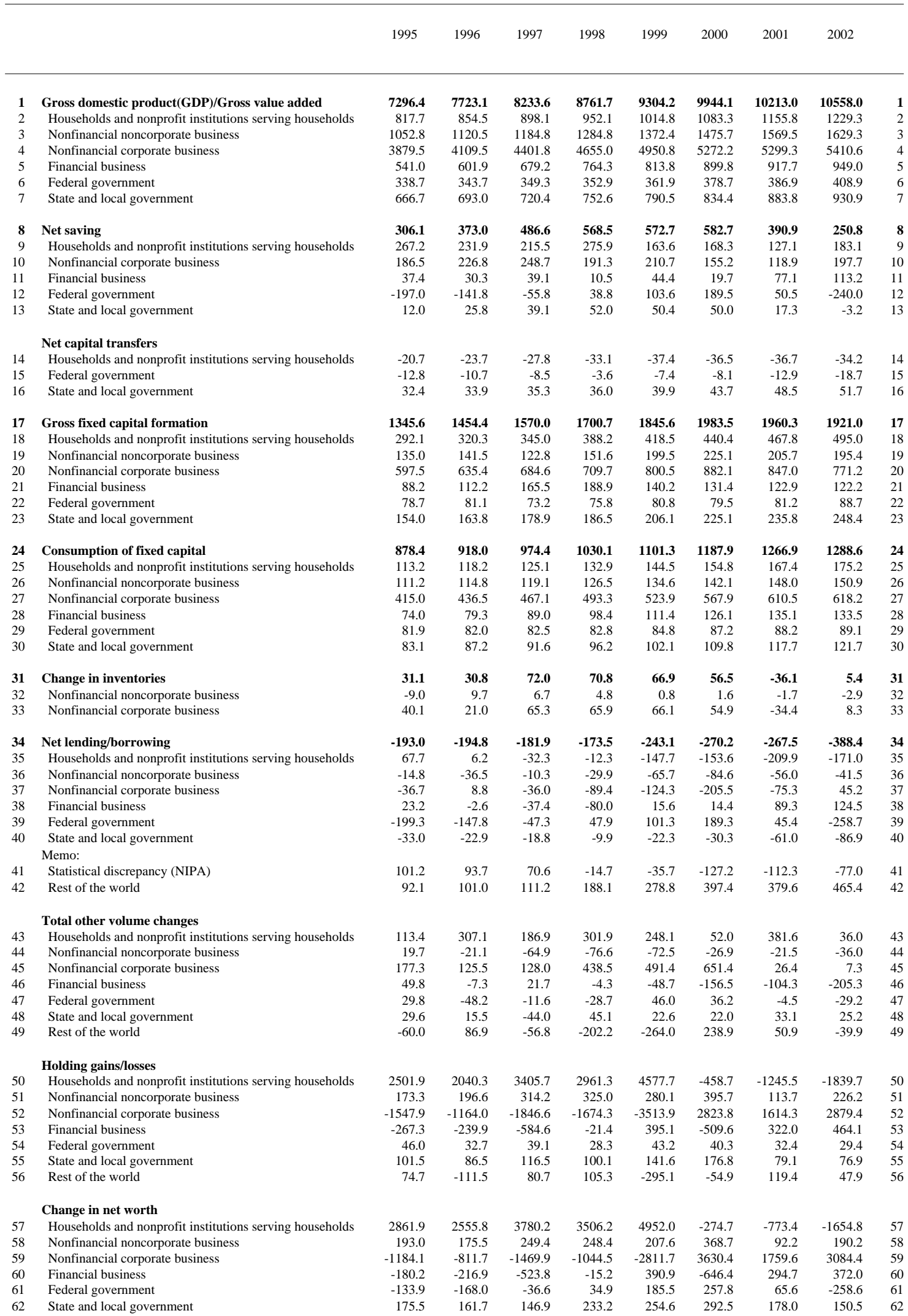




\section{Households and Nonprofit Institutions Serving Households}

Billions of dollars

$\begin{array}{llllllll}1995 & 1996 & 1997 & 1998 & 1999 & 2000 & 2001 & 2002\end{array}$

\section{CURRENT ACCOUNT:}

1 Gross domestic product(GDP)/Gross value added

2 Less consumption of fixed capital

Equals net domestic product/Net value added

Compensation paid by households and NPISHs

Wages and salaries

Employers' social contributions

Taxes on production and imports less subsidies

Operating surplus, net

9 Net national income/Balance of primary incomes, net

Operating surplus, net

Compensation of employees (received)

Wages and salaries

Employers' social contributions

Property income (received)

Interest

Distributed income of corporations

Dividends

Withdrawals from income of quasi-corporations

Less uses of property income (interest paid)

20 Net national income/Balance of primary incomes, net

21 Less current taxes on income, wealth, etc. (paid)

22 Plus social benefits (received)

Less social contributions (paid)

Plus other current transfers (received)

Less other current transfers (paid)

26 Equals disposable income, net

27 Less final consumption expenditures

28 Equals net saving

CAPITAL ACCOUNT:

$\begin{array}{ll}\mathbf{2 9} & \text { Net saving and capital transfers } \\ 30 & \text { Net saving } \\ 31 & \text { Capital transfers received (net) } \\ & \\ \mathbf{3 2} & \text { Capital formation, net } \\ 33 & \text { Gross fixed capital formation, excluding consumer durables } \\ 34 & \text { Residential } \\ 35 & \text { Nonresidential (nonprofit organizations) } \\ 36 & \text { Less consumption of fixed capital } \\ & \\ \mathbf{3 7} & \text { Net lending or borrowing, capital account (lines 29-32) }\end{array}$

FINANCIAL ACCOUNT:

$\begin{array}{ll}\mathbf{3 8} & \text { Net lending or borrowing, capital account (line 37) } \\ \mathbf{3 9} & \text { Net acquisition of financial assets } \\ & \\ \mathbf{4 0} & \text { Currency and deposits } \\ 41 & \text { Currency and transferable deposits } \\ 42 & \text { Other deposits } \\ 43 & \text { Foreign deposits } \\ 44 & \text { Time and savings deposits } \\ & \\ \mathbf{4 5} & \text { Securities other than shares } \\ 46 & \text { Open market paper } \\ 47 & \text { U.S. savings bonds } \\ 48 & \text { Treasury securities } \\ 49 & \text { Agency- and GSE-backed securities } \\ 50 & \text { Municipal securities } \\ 51 & \text { Corporate and foreign bonds } \\ & \\ \mathbf{5 2} & \text { Loans } \\ 53 & \text { Short-term (security credit) } \\ 54 & \text { Long-term (mortgages) } \\ & \\ \mathbf{5 5} & \text { Shares and other equity } \\ 56 & \text { Corporate equities } \\ 57 & \text { Mutual fund shares } \\ 58 & \text { Money market mutual fund shares } \\ 59 & \text { Equity in noncorporate business } \\ & \\ \mathbf{6 0} & \text { Insurance technical reserves } \\ & \end{array}$

$\begin{array}{rrrrrrrrr}\mathbf{8 1 7 . 7} & \mathbf{8 5 4 . 5} & \mathbf{8 9 8 . 1} & \mathbf{9 5 2 . 1} & \mathbf{1 0 1 4 . 8} & \mathbf{1 0 8 3 . 3} & \mathbf{1 1 5 5 . 8} & \mathbf{1 2 2 9 . 3} & \mathbf{1} \\ & & & & & & & & \\ \mathbf{1 1 3 . 2} & \mathbf{1 1 8 . 2} & \mathbf{1 2 5 . 1} & \mathbf{1 3 2 . 9} & \mathbf{1 4 4 . 5} & \mathbf{1 5 4 . 8} & \mathbf{1 6 7 . 4} & \mathbf{1 7 5 . 2} & \mathbf{2} \\ & & & & & & & & \\ \mathbf{7 0 4 . 5} & \mathbf{7 3 6 . 3} & \mathbf{7 7 3 . 0} & \mathbf{8 1 9 . 2} & \mathbf{8 7 0 . 3} & \mathbf{9 2 8 . 5} & \mathbf{9 8 8 . 4} & \mathbf{1 0 5 4 . 1} & \mathbf{3} \\ 320.3 & 333.7 & 349.8 & 374.3 & 394.2 & 421.4 & 443.4 & 474.6 & 4 \\ 276.3 & 289.9 & 306.1 & 327.2 & 344.0 & 367.4 & 387.0 & 412.9 & 5 \\ 44.0 & 43.8 & 43.8 & 47.2 & 50.2 & 54.0 & 56.5 & 61.7 & 6 \\ 83.7 & 87.8 & 92.4 & 95.8 & 100.6 & 105.6 & 112.0 & 121.2 & 7 \\ 300.5 & 314.8 & 330.8 & 349.0 & 375.5 & 401.6 & 433.0 & 458.3 & 8 \\ & & & & & & & & \\ \mathbf{5 6 9 2 . 6} & \mathbf{6 0 0 3 . 3} & \mathbf{6 3 8 8 . 7} & \mathbf{6 8 9 4 . 7} & \mathbf{7 2 6 7 . 2} & \mathbf{7 8 4 4 . 1} & \mathbf{8 0 3 7 . 2} & \mathbf{8 1 7 3 . 8} & \mathbf{9} \\ 300.5 & 314.8 & 330.8 & 349.0 & 375.5 & 401.6 & 433.0 & 458.3 & 10 \\ 4193.3 & 4390.5 & 4661.7 & 5019.4 & 5357.1 & 5782.7 & 5940.4 & 6019.1 & 11 \\ 3435.7 & 3623.2 & 3874.7 & 4182.7 & 4471.4 & 4829.2 & 4942.9 & 4974.6 & 12 \\ 757.7 & 767.3 & 787.0 & 836.7 & 885.7 & 953.4 & 997.6 & 1044.5 & 13 \\ 1563.9 & 1690.8 & 1817.6 & 1970.1 & 2002.3 & 2176.2 & 2208.7 & 2241.3 & 14 \\ 764.2 & 794.0 & 849.8 & 934.3 & 929.7 & 1012.1 & 1004.9 & 983.7 & 15 \\ 799.7 & 896.8 & 967.8 & 1035.8 & 1072.6 & 1164.1 & 1203.8 & 1257.6 & 16 \\ 253.2 & 296.2 & 333.0 & 349.9 & 335.6 & 376.1 & 371.2 & 396.2 & 17 \\ 546.5 & 600.6 & 634.8 & 685.9 & 737.0 & 788.0 & 832.6 & 861.4 & 18 \\ 365.1 & 392.8 & 421.4 & 443.8 & 467.7 & 516.4 & 544.9 & 544.9 & 19 \\ & & & & & & & & \\ \mathbf{5 6 9 2 . 6} & \mathbf{6 0 0 3 . 3} & \mathbf{6 3 8 8 . 7} & \mathbf{6 8 9 4 . 7} & \mathbf{7 2 6 7 . 2} & \mathbf{7 8 4 4 . 1} & \mathbf{8 0 3 7 . 2} & \mathbf{8 1 7 3 . 8} & \mathbf{2 0} \\ 744.1 & 832.1 & 926.3 & 1027.0 & 1107.5 & 1235.7 & 1243.7 & 1053.1 & 21 \\ 858.4 & 902.1 & 931.8 & 952.6 & 988.0 & 1041.6 & 1142.6 & 1249.5 & 22 \\ 532.8 & 555.2 & 587.2 & 624.2 & 661.4 & 702.7 & 728.5 & 750.3 & 23 \\ 19.0 & 22.9 & 19.4 & 26.0 & 34.1 & 42.4 & 49.9 & 42.6 & 24 \\ 50.1 & 52.3 & 63.5 & 66.7 & 74.3 & 82.0 & 85.0 & 94.1 & 25 \\ & & & & & & & & \\ \mathbf{5 2 4 3 . 0} & \mathbf{5 4 8 8 . 7} & \mathbf{5 7 6 2 . 9} & \mathbf{6 1 5 5 . 4} & \mathbf{6 4 4 6 . 1} & \mathbf{6 9 0 7 . 7} & \mathbf{7 1 7 2 . 5} & \mathbf{7 5 6 8 . 4} & \mathbf{2 6} \\ 4975.8 & 5256.8 & 5547.4 & 5879.5 & 6282.5 & 6739.4 & 7045.4 & 7385.3 & 27 \\ & & & & & & & & \\ \mathbf{2 6 7 . 2} & \mathbf{2 3 1 . 9} & \mathbf{2 1 5 . 5} & \mathbf{2 7 5 . 9} & \mathbf{1 6 3 . 6} & \mathbf{1 6 8 . 3} & \mathbf{1 2 7 . 1} & \mathbf{1 8 3 . 1} & \mathbf{2 8} \\ & & & & & & & & \end{array}$

$\begin{array}{rrrrrrrrr}\mathbf{2 4 6 . 6} & \mathbf{2 0 8 . 3} & \mathbf{1 8 7 . 6} & \mathbf{2 4 3 . 0} & \mathbf{1 2 6 . 3} & \mathbf{1 3 2 . 0} & \mathbf{9 0 . 5} & \mathbf{1 4 8 . 9} & \mathbf{2 9} \\ 267.2 & 231.9 & 215.5 & 275.9 & 163.6 & 168.3 & 127.1 & 183.1 & 30 \\ -20.7 & -23.7 & -27.8 & -33.1 & -37.4 & -36.5 & -36.7 & -34.2 & 31 \\ & & & & & & & & \\ \mathbf{1 7 8 . 9} & \mathbf{2 0 2 . 1} & \mathbf{2 1 9 . 9} & \mathbf{2 5 5 . 3} & \mathbf{2 7 4 . 0} & \mathbf{2 8 5 . 6} & \mathbf{3 0 0 . 4} & \mathbf{3 1 9 . 8} & \mathbf{3 2} \\ 292.1 & 320.3 & 345.0 & 388.2 & 418.5 & 440.4 & 467.8 & 495.0 & 33 \\ 254.8 & 280.8 & 293.2 & 329.9 & 359.8 & 377.3 & 401.6 & 429.8 & 34 \\ 37.3 & 39.5 & 51.8 & 58.3 & 58.7 & 63.1 & 66.2 & 65.3 & 35 \\ 113.2 & 118.2 & 125.1 & 132.9 & 144.5 & 154.8 & 167.4 & 175.2 & 36 \\ & & & & & & & & \\ \mathbf{6 7 . 7} & \mathbf{6 . 2} & \mathbf{- 3 2 . 3} & \mathbf{- 1 2 . 3} & \mathbf{- 1 4 7 . 7} & \mathbf{- 1 5 3 . 6} & \mathbf{- 2 0 9 . 9} & \mathbf{- 1 7 1 . 0} & \mathbf{3 7}\end{array}$

$\begin{array}{rrrrrrrrr}\mathbf{6 7 . 7} & \mathbf{6 . 2} & \mathbf{- 3 2 . 3} & \mathbf{- 1 2 . 3} & \mathbf{- 1 4 7 . 7} & \mathbf{- 1 5 3 . 6} & \mathbf{- 2 0 9 . 9} & \mathbf{- 1 7 1 . 0} & \mathbf{3 8} \\ & & & & & & & & \\ \mathbf{4 5 5 . 9} & \mathbf{5 0 7 . 6} & \mathbf{3 8 3 . 9} & \mathbf{6 0 1 . 2} & \mathbf{4 1 5 . 5} & \mathbf{3 0 5 . 7} & \mathbf{5 8 9 . 4} & \mathbf{4 1 9 . 3} & \mathbf{3 9} \\ & & & & & & & & \\ \mathbf{9 0 . 4} & \mathbf{9 1 . 2} & \mathbf{1 0 5 . 7} & \mathbf{1 4 4 . 6} & \mathbf{3 8 . 9} & \mathbf{1 8 8 . 3} & \mathbf{3 4 2 . 9} & \mathbf{2 8 1 . 1} & \mathbf{4 0} \\ -40.8 & -72.9 & -33.7 & -16.2 & -75.4 & -120.5 & 93.7 & -18.2 & 41 \\ 131.2 & 164.1 & 139.4 & 160.9 & 114.3 & 308.7 & 249.2 & 299.3 & 42 \\ 4.6 & 12.4 & 6.5 & 0.1 & 5.2 & 20.0 & -5.0 & 10.7 & 43 \\ 126.6 & 151.7 & 132.9 & 160.7 & 109.1 & 288.8 & 254.2 & 288.7 & 44 \\ & & & & & & & & \\ \mathbf{3 0 . 3} & \mathbf{1 2 7 . 4} & \mathbf{- 4 3 . 3} & \mathbf{9 5 . 6} & \mathbf{1 3 8 . 5} & \mathbf{- 9 8 . 7} & \mathbf{- 1 3 8 . 3} & \mathbf{- 7 1 . 3} & \mathbf{4 5} \\ 2.0 & 4.1 & 1.3 & 3.0 & 4.7 & 2.4 & -33.9 & 5.6 & 46 \\ 5.1 & 2.0 & -0.5 & 0.1 & -0.2 & -1.7 & 5.6 & 4.5 & 47 \\ -30.0 & -14.2 & -150.2 & -40.9 & 29.5 & -170.5 & -88.9 & -71.2 & 48 \\ 27.3 & 100.8 & 52.7 & 39.8 & 114.0 & 79.1 & -57.6 & -143.9 & 49 \\ -58.9 & -35.3 & 23.5 & 5.0 & 34.4 & 9.2 & 47.7 & 108.0 & 50 \\ 84.8 & 70.0 & 30.0 & 88.5 & -44.0 & -17.4 & -11.2 & 25.7 & 51 \\ & & & & & & & & \\ \mathbf{1 1 . 1} & \mathbf{2 7 . 9} & \mathbf{4 4 . 4} & \mathbf{5 8 . 3} & \mathbf{5 4 . 8} & \mathbf{9 9 . 8} & \mathbf{5 0 . 2} & \mathbf{- 3 1 . 1} & \mathbf{5 2} \\ 18.6 & 35.3 & 52.6 & 61.2 & 47.2 & 88.6 & 41.9 & -41.6 & 53 \\ -7.5 & -7.4 & -8.2 & -3.0 & 7.6 & 11.3 & 8.3 & 10.5 & 54 \\ & & & & & & & & \\ \mathbf{1 0 3 . 7} & \mathbf{5 3 . 9} & \mathbf{4 . 8} & \mathbf{1 7 . 3} & \mathbf{- 4 . 6} & \mathbf{- 1 1 6 . 1} & \mathbf{4 7 . 8} & \mathbf{- 5 4 . 8} & \mathbf{5 5} \\ -101.2 & -187.1 & -240.2 & -321.8 & -110.7 & -476.7 & -264.4 & -112.4 & 56 \\ 87.4 & 195.2 & 228.5 & 278.5 & 65.8 & 217.5 & 186.5 & 154.8 & 57 \\ 101.4 & 58.3 & 75.9 & 139.5 & 119.6 & 152.7 & 150.6 & -41.6 & 58 \\ 16.0 & -12.5 & -59.4 & -78.8 & -79.3 & -9.6 & -24.9 & -55.6 & 59 \\ & & & & & & & & \\ \mathbf{2 2 1 . 2} & \mathbf{2 0 3 . 3} & \mathbf{2 7 3 . 6} & \mathbf{2 7 6 . 9} & \mathbf{1 9 0 . 5} & \mathbf{2 3 1 . 2} & \mathbf{2 7 9 . 0} & \mathbf{2 9 8 . 1} & \mathbf{6 0}\end{array}$




\section{Households and Nonprofit Institutions Serving Households}

Billions of dollars

\begin{tabular}{|c|c|c|c|c|c|c|c|c|c|}
\hline & & 1995 & 1996 & 1997 & 1998 & 1999 & 2000 & 2001 & 2002 \\
\hline 61 & Net equity in life insurance and pension funds & 204.5 & 192.8 & 261.0 & 264.9 & 178.0 & 224.7 & 260.5 & 269.4 \\
\hline 62 & Net equity in life insurance reserves & 45.8 & 44.5 & 59.3 & 48.0 & 50.8 & 50.2 & 77.2 & 60.1 \\
\hline 63 & Net equity in pension fund reserves & 158.7 & 148.3 & 201.7 & 216.9 & 127.3 & 174.5 & 183.4 & 209.3 \\
\hline 64 & Prepayments of premiums and reserves against claims & 16.7 & 10.6 & 12.7 & 12.1 & 12.4 & 6.5 & 18.5 & 28.7 \\
\hline 65 & Net equity in reserves of other insurance companies & 8.7 & 2.7 & 2.0 & 1.8 & 1.1 & -0.3 & 11.9 & 18.5 \\
\hline 66 & Net equity in other life insurance company reserves & 8.0 & 7.8 & 10.7 & 10.3 & 11.4 & 6.9 & 6.5 & 10.2 \\
\hline 67 & Other accounts receivable (miscellaneous assets) & -0.9 & 3.9 & -1.4 & 8.4 & -2.5 & 1.2 & 7.7 & -2.6 \\
\hline 68 & Net incurrence of liabilities & 337.4 & 357.1 & 350.5 & 465.2 & 571.3 & 574.9 & 599.1 & 700.0 \\
\hline 69 & Securities other than shares (municipals) & 0.7 & 6.6 & 10.0 & 12.0 & 10.4 & 5.8 & 13.8 & 12.9 \\
\hline 70 & Loans & 328.1 & 341.7 & 331.3 & 445.9 & $\mathbf{5 5 4 . 7}$ & 565.2 & $\mathbf{5 8 1 . 7}$ & 679.2 \\
\hline 71 & Short-term & 180.0 & 125.8 & 108.6 & 125.8 & 175.0 & 181.2 & 83.0 & 30.2 \\
\hline 72 & Consumer credit & 147.0 & 103.6 & 62.1 & 96.8 & 112.1 & 165.2 & 137.7 & 81.4 \\
\hline 73 & Bank loans n.e.c. & 17.4 & 0.5 & 8.0 & 7.7 & -6.9 & 6.8 & -16.5 & -3.1 \\
\hline 74 & Other loans and advances & 12.0 & 5.8 & 1.7 & -0.3 & -5.4 & 2.0 & 0.6 & 0.1 \\
\hline 75 & Security credit & 3.5 & 15.8 & 36.8 & 21.6 & 75.2 & 7.2 & -38.8 & -48.2 \\
\hline 76 & Long-term (mortgages) & 148.1 & 215.8 & 222.7 & 320.1 & 379.7 & 383.9 & 498.7 & 649.0 \\
\hline 77 & Insurance technical reserves (unpaid premiums) & 0.7 & 0.8 & 0.3 & -1.4 & 2.1 & 0.1 & -0.4 & 0.9 \\
\hline 78 & Other accounts payable (trade debt) & 7.9 & 8.0 & 8.9 & 8.7 & 4.1 & 3.8 & 4.0 & 7.0 \\
\hline \multicolumn{3}{|c|}{ Memo: } & 150.5 & 33.4 & 136.0 & -155.8 & -269.2 & -9.7 & -280.6 \\
\hline
\end{tabular}

OTHER CHANGES IN VOLUME ACCOUNT:

$\begin{array}{ll}80 & \text { Total other volume changes } \\ 81 & \text { Net investment in consumer durable goods } \\ 82 & \text { Other volume changes } \\ 83 & \text { Less statistical discrepancy (lines 37-[39-68])* }\end{array}$

REVALUATION ACCOUNT:

$\begin{array}{ll}\mathbf{8 4} & \text { Nonfinancial assets } \\ 85 & \text { Real estate } \\ 86 & \text { Consumer durable goods } \\ 87 & \text { Equipment and software } \\ & \\ \mathbf{8 8} & \text { Financial assets } \\ 89 & \text { Shares and other equity } \\ 90 & \text { Corporate equities } \\ 91 & \text { Mutual fund shares } \\ 92 & \text { Equity in noncorporate business } \\ 93 & \text { Insurance technical reserves } \\ & \\ \mathbf{9 4} & \text { Changes in net worth due to nominal holding gains/losses }\end{array}$

\section{CHANGES IN BALANCE SHEET ACCOUNT:}

95

Change in net worth (lines $32+37+80+94)$

\section{BALANCE SHEET ACCOUNT (end of period):}

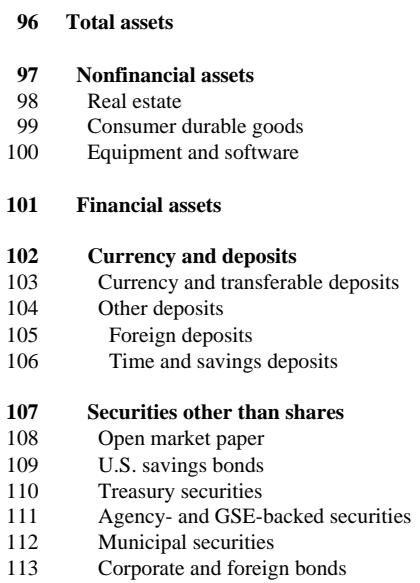

$\begin{array}{rrrrrrrrr}\mathbf{3 2 9 . 7} & \mathbf{1 5 9 . 2} & \mathbf{3 1 3 . 1} & \mathbf{5 8 6 . 7} & \mathbf{6 0 0 . 5} & \mathbf{8 1 4 . 6} & \mathbf{7 3 4 . 4} & \mathbf{9 0 3 . 0} & \mathbf{8 4} \\ 325.8 & 174.4 & 350.1 & 627.6 & 645.6 & 841.2 & 799.2 & 978.6 & 85 \\ 4.3 & -14.5 & -35.5 & -39.2 & -44.5 & -26.1 & -64.1 & -74.6 & 86 \\ -0.4 & -0.8 & -1.5 & -1.7 & -0.6 & -0.5 & -0.8 & -0.9 & 87 \\ & & & & & & & & \\ \mathbf{2 1 7 2 . 2} & \mathbf{1 8 8 1 . 2} & \mathbf{3 0 9 2 . 6} & \mathbf{2 3 7 4 . 6} & \mathbf{3 9 7 7 . 2} & \mathbf{- 1 2 7 3 . 4} & \mathbf{- 1 9 7 9 . 9} & \mathbf{- 2 7 4 2 . 7} & \mathbf{8 8} \\ 1695.0 & 1507.1 & 2547.8 & 1876.5 & 3319.6 & -1045.4 & -1503.6 & -2081.8 & 89 \\ 1356.4 & 1080.2 & 1960.6 & 1327.9 & 2438.3 & -1148.1 & -1255.8 & -1843.9 & 90 \\ 136.9 & 176.5 & 236.6 & 217.8 & 569.2 & -295.3 & -380.8 & -483.9 & 91 \\ 201.7 & 250.5 & 348.9 & 330.8 & 312.0 & 398.0 & 132.9 & 246.0 & 92 \\ 477.2 & 374.0 & 544.8 & 498.1 & 657.6 & -228.0 & -476.3 & -660.9 & 93 \\ & & & & & & & & \\ \mathbf{2 5 0 1 . 9} & \mathbf{2 0 4 0 . 3} & \mathbf{3 4 0 5 . 7} & \mathbf{2 9 6 1 . 3} & \mathbf{4 5 7 7 . 7} & \mathbf{- 4 5 8 . 7} & \mathbf{- 1 2 4 5 . 5} & \mathbf{- 1 8 3 9 . 7} & \mathbf{9 4}\end{array}$

$\begin{array}{lllllllll}2861.9 & 2555.8 & 3780.2 & 3506.2 & 4952.0 & -274.7 & -773.4 & -1654.8 & 95\end{array}$

$\begin{array}{rrrrrrrrr}\mathbf{3 2 6 1 8 . 1} & \mathbf{3 5 5 3 1 . 0} & \mathbf{3 9 6 6 1 . 9} & \mathbf{4 3 6 3 3 . 3} & \mathbf{4 9 1 5 7 . 1} & \mathbf{4 9 4 6 8 . 3} & \mathbf{4 9 2 9 3 . 9} & \mathbf{4 8 3 3 9 . 1} & \mathbf{9 6} \\ & & & & & & & & \\ \mathbf{1 1 0 4 8 . 3} & \mathbf{1 1 5 1 2 . 8} & \mathbf{1 2 1 7 1 . 1} & \mathbf{1 3 1 7 3 . 6} & \mathbf{1 4 2 4 3 . 8} & \mathbf{1 5 5 5 9 . 3} & \mathbf{1 6 7 8 9 . 0} & \mathbf{1 8 2 0 1 . 6} & \mathbf{9 7} \\ 8687.8 & 9053.5 & 9613.5 & 10488.6 & 11399.9 & 12529.0 & 13624.4 & 14907.8 & 98 \\ 2296.0 & 2392.8 & 2486.6 & 2608.3 & 2760.9 & 2940.7 & 3070.1 & 3195.7 & 99 \\ 64.6 & 66.6 & 71.0 & 76.7 & 83.0 & 89.5 & 94.5 & 98.0 & 100 \\ & & & & & & & & \\ \mathbf{2 1 5 6 9 . 8} & \mathbf{2 4 0 1 8 . 1} & \mathbf{2 7 4 9 0 . 9} & \mathbf{3 0 4 5 9 . 7} & \mathbf{3 4 9 1 3 . 3} & \mathbf{3 3 9 0 9 . 0} & \mathbf{3 2 5 0 5 . 0} & \mathbf{3 0 1 3 7 . 5} & \mathbf{1 0 1} \\ & & & & & & & & \\ \mathbf{2 8 5 9 . 0} & \mathbf{2 9 4 9 . 9} & \mathbf{3 0 5 0 . 8} & \mathbf{3 1 9 6 . 5} & \mathbf{3 2 3 5 . 3} & \mathbf{3 4 2 3 . 6} & \mathbf{3 7 6 6 . 5} & \mathbf{4 0 4 7 . 6} & \mathbf{1 0 2} \\ 544.3 & 471.4 & 437.7 & 421.5 & 346.0 & 225.5 & 319.2 & 301.0 & 103 \\ 2314.7 & 2478.5 & 2613.1 & 2775.0 & 2889.3 & 3198.1 & 3447.3 & 3746.6 & 104 \\ 23.4 & 35.5 & 37.2 & 38.3 & 43.5 & 63.5 & 58.5 & 69.2 & 105 \\ 2291.3 & 2443.1 & 2575.9 & 2736.7 & 2845.8 & 3134.6 & 3388.8 & 3677.4 & 106 \\ & & & & & & & & \\ \mathbf{2 0 5 1 . 4} & \mathbf{2 2 3 8 . 7} & \mathbf{2 1 9 6 . 5} & \mathbf{2 2 8 4 . 1} & \mathbf{2 4 8 3 . 5} & \mathbf{2 3 4 8 . 2} & \mathbf{2 1 9 6 . 3} & \mathbf{2 0 8 0 . 9} & \mathbf{1 0 7} \\ 71.7 & 75.8 & 77.1 & 80.2 & 84.9 & 87.3 & 53.4 & 59.0 & 108 \\ 185.0 & 187.0 & 186.5 & 186.6 & 186.4 & 184.8 & 190.3 & 194.9 & 109 \\ 626.0 & 673.7 & 570.0 & 528.5 & 629.6 & 426.1 & 327.6 & 221.2 & 110 \\ 116.7 & 215.3 & 260.4 & 292.8 & 397.5 & 468.9 & 407.5 & 254.6 & 111 \\ 539.7 & 504.5 & 511.1 & 516.1 & 550.5 & 559.8 & 607.5 & 715.5 & 112 \\ 512.3 & 582.3 & 591.4 & 679.9 & 634.6 & 621.3 & 610.0 & 635.7 & 113\end{array}$


3. Households and Nonprofit Institutions Serving Households

Billions of dollars

\begin{tabular}{|c|c|c|c|c|c|c|c|c|c|c|}
\hline & & 1995 & 1996 & 1997 & 1998 & 1999 & 2000 & 2001 & 2002 & \\
\hline 114 & Loans & 247.2 & 275.1 & 319.5 & 377.8 & 432.6 & 532.4 & 582.6 & 551.5 & 114 \\
\hline 115 & Short-term (security credit) & 127.6 & 162.9 & 215.5 & 276.7 & 323.9 & 412.4 & 454.3 & 412.7 & 115 \\
\hline 116 & Long-term (mortgages) & 119.6 & 112.3 & 104.1 & 101.1 & 108.7 & 120.0 & 128.3 & 138.8 & 116 \\
\hline 117 & Shares and other equity & 10120.7 & 11681.7 & 14234.3 & 16128.1 & 19443.1 & 18281.7 & 16825.8 & 14689.2 & 117 \\
\hline 118 & Corporate equities & 4640.3 & 5533.3 & 7253.8 & 8259.8 & 10587.5 & 8962.7 & 7442.6 & 5486.2 & 118 \\
\hline 119 & Mutual fund shares & 1406.6 & 1778.3 & 2243.4 & 2739.7 & 3374.7 & 3296.9 & 3102.7 & 2773.6 & 119 \\
\hline 120 & Money market mutual fund shares & 483.8 & 542.1 & 619.6 & 759.1 & 878.7 & 1031.4 & 1181.9 & 1140.3 & 120 \\
\hline 121 & Equity in noncorporate business & 3590.0 & 3828.0 & 4117.5 & 4369.4 & 4602.2 & 4990.6 & 5098.7 & 5289.0 & 121 \\
\hline 122 & Insurance technical reserves & 6279.4 & 6856.7 & 7675.2 & 8450.2 & 9298.3 & 9301.5 & 9104.2 & 8741.5 & 122 \\
\hline 123 & Net equity in life insurance and pension funds & 5963.1 & 6529.9 & 7335.7 & 8098.7 & 8933.9 & 8930.6 & 8714.9 & 8323.5 & 123 \\
\hline 124 & Net equity in life insurance reserves & 566.2 & 610.6 & 665.0 & 718.3 & 783.9 & 819.1 & 880.0 & 920.9 & 124 \\
\hline 125 & Net equity in pension fund reserves & 5396.9 & 5919.3 & 6670.7 & 7380.4 & 8150.1 & 8111.5 & 7834.9 & 7402.5 & 125 \\
\hline 126 & Prepayments of premiums and reserves against claims & 316.3 & 326.8 & 339.5 & 351.5 & 364.3 & 370.9 & 389.4 & 418.1 & 126 \\
\hline 127 & Net equity in reserves of other insurance companies & 194.7 & 197.5 & 199.5 & 201.3 & 202.3 & 202.0 & 214.0 & 232.4 & 127 \\
\hline 128 & Net equity in other life insurance company reserves & 121.5 & 129.3 & 140.0 & 150.3 & 162.0 & 168.9 & 175.4 & 185.6 & 128 \\
\hline 129 & Other accounts receivable (miscellaneous assets) & 12.1 & 16.0 & 14.6 & 23.0 & 20.5 & 21.7 & 29.4 & 26.8 & 129 \\
\hline 130 & Total liabilities and net worth & 32618.1 & 35531.0 & 39661.9 & 43633.3 & 49157.1 & 49468.3 & 49293.9 & 48339.1 & 130 \\
\hline 131 & Liabilities & 5072.8 & 5429.9 & 5780.6 & 6245.8 & 6817.5 & 7403.5 & 8002.6 & 8702.6 & 131 \\
\hline 132 & Securities other than shares (municipals) & 98.3 & 104.9 & 114.9 & 126.9 & 137.3 & 143.0 & 156.9 & 169.8 & 132 \\
\hline 133 & Loans & 4855.9 & 5197.6 & 5529.1 & 5975.0 & 6529.9 & 7106.2 & 7687.9 & 8367.1 & 133 \\
\hline 134 & Short-term & 1419.7 & 1545.5 & 1654.6 & 1780.4 & 1955.7 & 2148.1 & 2231.1 & 2261.3 & 134 \\
\hline 135 & Consumer credit & 1168.0 & 1271.7 & 1333.8 & 1430.6 & 1542.7 & 1719.0 & 1856.7 & 1938.1 & 135 \\
\hline 136 & Bank loans n.e.c. & 57.4 & 58.0 & 66.5 & 74.2 & 67.3 & 74.1 & 57.6 & 54.6 & 136 \\
\hline 137 & Other loans and advances & 115.7 & 121.5 & 123.2 & 122.9 & 117.8 & 119.8 & 120.4 & 120.5 & 137 \\
\hline 138 & Security credit & 78.6 & 94.4 & 131.2 & 152.8 & 227.9 & 235.1 & 196.4 & 148.2 & 138 \\
\hline 139 & Long-term (mortgages) & 3436.2 & 3652.0 & 3874.5 & 4194.5 & 4574.2 & 4958.1 & 5456.8 & 6105.8 & 139 \\
\hline 140 & Insurance technical reserves (unpaid premiums) & 17.5 & 18.3 & 18.6 & 17.2 & 19.4 & 19.6 & 19.1 & 20.0 & 140 \\
\hline 141 & Other accounts payable (trade debt) & 101.1 & 109.1 & 118.0 & 126.8 & 130.9 & 134.7 & 138.7 & 145.7 & 141 \\
\hline 142 & Net worth & 27545.3 & 30101.1 & 33881.3 & 37387.5 & 42339.5 & 42064.8 & 41291.3 & 39636.5 & 142 \\
\hline
\end{tabular}

* The discrepancy is the difference between net lending or borrowing derived in the capital account and the same concept derived in the financial account. The discrepancy reflects differences in source data, timing of recorded flows, and other statistical differences between the capital and financial accounts. 


\section{Nonfinancial Noncorporate Business}

Billions of dollars

$\begin{array}{llllllll}1995 & 1996 & 1997 & 1998 & 1999 & 2000 & 2001 & 2002\end{array}$

\section{CURRENT ACCOUNT:}

1 Gross domestic product(GDP)/Gross value added

2 Less consumption of fixed capital

Equals net domestic product/Net value added

Compensation of employees (paid)

Wages and salaries

Employers' social contributions

Taxes on production and imports less subsidies

Operating surplus, net

Net national income/Balance of primary incomes, net Operating surplus, net

Property income (interest received)

Less uses of property income (paid)

Interest

Withdrawals from income of quasi-corporation

Reinvested earnings on foreign direct investment

Rents

17 Net national income/Balance of primary incomes, net

18 Less other current transfers (paid)

19 Equals disposable income, net

20 Equals net saving
$21 \quad$ Net saving

2 Capital formation, net

Gross fixed capital formation

Nonresidential

Residential

Less consumption of fixed capital

Change in inventories

28 Net lending or borrowing, capital account (lines 21-22)

FINANCIAL ACCOUNT:

29 Net lending or borrowing (line 28)

30 Net acquisition of financial assets

31 Currency and deposits

32 Currency and transferable deposits

33 Time and savings deposits

34 Securities other than shares

35 Treasury securities

36 Municipal securities

37 Loans

38 Short-term (consumer credit)

39 Long-term (mortgages)

40 Shares and other equity

41 Money market mutual fund shares

42 Equity in government-sponsored enterprises

Insurance technical reserves (net equity in reserves of

43 other insurance companies)

44 Other accounts receivable

45 Trade receivables

46 Other (miscellaneous assets)

$47 \quad$ Net incurrence of liabilities

48 Loans

49 Short-term

Bank loans n.e.c.

Other loans and advances

Long-term (mortgages)

Shares and other equity

Equity in noncorporate business

Foreign direct investment in U.S.

$\begin{array}{rrrrrrrrr}\mathbf{1 0 5 2 . 8} & \mathbf{1 1 2 0 . 5} & \mathbf{1 1 8 4 . 8} & \mathbf{1 2 8 4 . 8} & \mathbf{1 3 7 2 . 4} & \mathbf{1 4 7 5 . 7} & \mathbf{1 5 6 9 . 5} & \mathbf{1 6 2 9 . 3} & \mathbf{1} \\ \mathbf{1 1 1 . 2} & \mathbf{1 1 4 . 8} & \mathbf{1 1 9 . 1} & \mathbf{1 2 6 . 5} & \mathbf{1 3 4 . 6} & \mathbf{1 4 2 . 1} & \mathbf{1 4 8 . 0} & \mathbf{1 5 0 . 9} & \mathbf{2} \\ \mathbf{9 4 1 . 6} & \mathbf{1 0 0 5 . 7} & \mathbf{1 0 6 5 . 7} & \mathbf{1 1 5 8 . 3} & \mathbf{1 2 3 7 . 8} & \mathbf{1 3 3 3 . 6} & \mathbf{1 4 2 1 . 5} & \mathbf{1 4 7 8 . 4} & \mathbf{3} \\ 255.3 & 269.7 & 286.2 & 311.4 & 341.2 & 367.6 & 390.7 & 405.9 & 4 \\ 222.3 & 235.9 & 251.6 & 273.7 & 299.8 & 322.6 & 343.8 & 355.8 & 5 \\ 33.0 & 33.8 & 34.6 & 37.7 & 41.4 & 45.0 & 46.9 & 50.1 & 6 \\ 52.6 & 56.7 & 65.0 & 72.5 & 72.5 & 74.1 & 80.6 & 91.5 & 7 \\ 633.6 & 679.2 & 714.5 & 774.4 & 824.1 & 891.8 & 950.2 & 980.9 & 8 \\ & & & & & & & & \\ \mathbf{6 . 2} & \mathbf{7 . 8} & \mathbf{8 . 5} & \mathbf{7 . 4} & \mathbf{8 . 8} & \mathbf{9 . 0} & \mathbf{7 . 8} & \mathbf{1 2 . 4} & \mathbf{9} \\ 633.6 & 679.2 & 714.5 & 774.4 & 824.1 & 891.8 & 950.2 & 980.9 & 10 \\ 9.1 & 10.4 & 11.8 & 12.6 & 13.3 & 13.3 & 15.8 & 17.4 & 11 \\ 636.6 & 681.8 & 717.8 & 779.6 & 828.5 & 896.1 & 958.2 & 986.0 & 12 \\ 126.1 & 128.8 & 136.1 & 148.7 & 159.7 & 182.7 & 192.7 & 194.4 & 13 \\ 510.4 & 553.0 & 581.6 & 630.9 & 668.8 & 713.4 & 765.6 & 791.6 & 14 \\ 0.1 & 0 & 0.1 & 0 & 0 & 0 & -0.1 & 0 & 15 \\ 0 & 0 & 0 & 0 & 0 & 0 & 0 & 0 & 16 \\ & & & & & & & & \\ \mathbf{6 . 2} & \mathbf{7 . 8} & \mathbf{8 . 5} & \mathbf{7 . 4} & \mathbf{8 . 8} & \mathbf{9 . 0} & \mathbf{7 . 8} & \mathbf{1 2 . 4} & \mathbf{1 7} \\ 6.2 & 7.8 & 8.5 & 7.4 & 8.8 & 9.0 & 7.8 & 12.4 & 18 \\ & & & & & & & & \\ \mathbf{0} & \mathbf{0} & \mathbf{0} & \mathbf{0} & \mathbf{0} & \mathbf{0} & \mathbf{0} & \mathbf{0} & \mathbf{1 9} \\ & \mathbf{0} & \mathbf{0} & \mathbf{0} & \mathbf{0} & \mathbf{0} & \mathbf{0} & \mathbf{0} & \mathbf{2 0}\end{array}$

$\begin{array}{rrrrrrrrr}\mathbf{0} & \mathbf{0} & \mathbf{0} & \mathbf{0} & \mathbf{0} & \mathbf{0} & \mathbf{0} & \mathbf{0} & \mathbf{2 1} \\ & & & & & & & & \\ \mathbf{1 4 . 8} & \mathbf{3 6 . 5} & \mathbf{1 0 . 3} & \mathbf{2 9 . 9} & \mathbf{6 5 . 7} & \mathbf{8 4 . 6} & \mathbf{5 6 . 0} & \mathbf{4 1 . 5} & \mathbf{2 2} \\ 135.0 & 141.5 & 122.8 & 151.6 & 199.5 & 225.1 & 205.7 & 195.4 & 23 \\ 92.4 & 95.2 & 81.0 & 109.9 & 139.4 & 159.0 & 142.3 & 127.4 & 24 \\ 42.6 & 46.3 & 41.8 & 41.7 & 60.1 & 66.1 & 63.4 & 68.0 & 25 \\ 111.2 & 114.8 & 119.1 & 126.5 & 134.6 & 142.1 & 148.0 & 150.9 & 26 \\ -9.0 & 9.7 & 6.7 & 4.8 & 0.8 & 1.6 & -1.7 & -2.9 & 27 \\ & & & & & & & & \\ \mathbf{- 1 4 . 8} & \mathbf{- 3 6 . 5} & \mathbf{- 1 0 . 3} & \mathbf{- 2 9 . 9} & \mathbf{- 6 5 . 7} & \mathbf{- 8 4 . 6} & \mathbf{- 5 6 . 0} & \mathbf{- 4 1 . 5} & \mathbf{2 8}\end{array}$

$\begin{array}{rrrrrrrrr}\mathbf{- 1 4 . 8} & \mathbf{- 3 6 . 5} & \mathbf{- 1 0 . 3} & \mathbf{- 2 9 . 9} & \mathbf{- 6 5 . 7} & \mathbf{- 8 4 . 6} & \mathbf{- 5 6 . 0} & \mathbf{- 4 1 . 5} & \mathbf{2 9} \\ \mathbf{7 5 . 6} & \mathbf{9 2 . 8} & \mathbf{1 2 7 . 7} & \mathbf{2 1 1 . 4} & \mathbf{1 7 6 . 8} & \mathbf{2 3 7 . 4} & \mathbf{1 4 8 . 2} & \mathbf{1 4 3 . 5} & \mathbf{3 0} \\ & & & & & & & & \\ \mathbf{1 8 . 0} & \mathbf{2 2 . 8} & \mathbf{3 3 . 2} & \mathbf{4 7 . 2} & \mathbf{5 8 . 4} & \mathbf{7 6 . 7} & \mathbf{8 . 3} & \mathbf{1 5 . 4} & \mathbf{3 1} \\ 13.7 & 19.3 & 22.5 & 34.4 & 39.3 & 56.6 & 1.1 & 13.2 & 32 \\ 4.3 & 3.5 & 10.7 & 12.7 & 19.1 & 20.1 & 7.1 & 2.2 & 33 \\ & & & & & & & & \\ \mathbf{5 . 9} & \mathbf{5 . 3} & \mathbf{4 . 2} & \mathbf{5 . 4} & \mathbf{- 0 . 9} & \mathbf{2 . 7} & \mathbf{3 . 7} & \mathbf{2 . 5} & \mathbf{3 4} \\ 5.3 & 4.9 & 3.7 & 5.7 & -0.8 & 3.0 & 2.7 & 2.3 & 35 \\ 0.6 & 0.4 & 0.5 & -0.4 & -0.1 & -0.3 & 1.1 & 0.2 & 36 \\ & & & & & & & & \\ \mathbf{- 2 . 1} & \mathbf{- 1 . 4} & \mathbf{- 1 . 6} & \mathbf{7 . 9} & \mathbf{- 2 . 0} & \mathbf{- 1 . 4} & \mathbf{3 . 3} & \mathbf{1 . 2} & \mathbf{3 7} \\ 0 & 0 & 0 & 0 & 0 & 0 & 0 & 0 & 38 \\ -2.1 & -1.4 & -1.6 & 7.9 & -2.0 & -1.4 & 3.3 & 1.2 & 39 \\ & & & & & & & & \\ \mathbf{1 . 9} & \mathbf{2 . 2} & \mathbf{3 . 7} & \mathbf{9 . 7} & \mathbf{8 . 1} & \mathbf{8 . 7} & \mathbf{9 . 6} & \mathbf{2 . 4} & \mathbf{4 0} \\ 1.9 & 2.2 & 3.7 & 9.7 & 8.1 & 8.7 & 9.6 & 2.3 & 41 \\ -0.1 & 0.0 & 0 & 0.1 & -0.0 & -0.0 & 0.0 & 0.1 & 42 \\ & & & & & & & & \\ \mathbf{3 . 9} & \mathbf{1 . 2} & \mathbf{0 . 9} & \mathbf{0 . 8} & \mathbf{0 . 5} & \mathbf{- 0 . 2} & \mathbf{3 . 9} & \mathbf{8 . 2} & \mathbf{4 3} \\ & & & & & & & & \\ \mathbf{5 0 . 0} & \mathbf{6 4 . 8} & \mathbf{9 1 . 0} & \mathbf{1 5 0 . 1} & \mathbf{1 2 0 . 8} & \mathbf{1 5 9 . 6} & \mathbf{1 2 9 . 0} & \mathbf{1 1 6 . 2} & \mathbf{4 4} \\ 15.3 & 29.5 & 35.1 & 28.2 & 39.4 & 69.6 & 1.8 & 22.8 & 45 \\ 34.7 & 35.2 & 55.9 & 121.9 & 81.4 & 90.0 & 127.3 & 93.4 & 46 \\ & & & & & & & & \\ \mathbf{9 0 . 4} & \mathbf{1 2 9 . 3} & \mathbf{1 3 8 . 0} & \mathbf{2 4 1 . 4} & \mathbf{2 4 2 . 5} & \mathbf{3 2 1 . 9} & \mathbf{2 0 4 . 2} & \mathbf{1 8 5 . 1} & \mathbf{4 7} \\ & & & & & & & & \\ \mathbf{4 8 . 9} & \mathbf{7 2 . 2} & \mathbf{1 0 0 . 9} & \mathbf{1 9 0 . 0} & \mathbf{1 9 4 . 8} & \mathbf{2 0 3 . 7} & \mathbf{1 6 6 . 7} & \mathbf{1 5 6 . 9} & \mathbf{4 8} \\ 19.7 & 31.3 & 50.1 & 39.3 & 54.0 & 59.7 & 38.0 & 16.0 & 49 \\ 11.8 & 29.5 & 47.3 & 26.0 & 45.6 & 47.0 & 37.8 & 12.5 & 50 \\ 7.9 & 1.8 & 2.8 & 13.3 & 8.4 & 12.8 & 0.3 & 3.5 & 51 \\ 29.2 & 40.9 & 50.8 & 150.7 & 140.8 & 144.0 & 128.7 & 140.9 & 52 \\ & & & & & & & & \\ \mathbf{1 4 . 0} & \mathbf{- 6 . 5} & \mathbf{- 5 5 . 6} & \mathbf{- 7 6 . 4} & \mathbf{- 7 0 . 1} & \mathbf{- 2 6 . 9} & \mathbf{- 1 4 . 2} & \mathbf{- 2 2 . 2} & \mathbf{5 3} \\ 14.1 & -6.8 & -56.1 & -76.6 & -70.3 & -27.0 & -14.3 & -22.4 & 54 \\ -0.1 & 0.3 & 0.5 & 0.2 & 0.2 & 0.1 & 0.1 & 0.2 & 55 \\ & & & & & & & & \end{array}$




\section{Nonfinancial Noncorporate Business}

Billions of dollars

$\begin{array}{llllllll}1995 & 1996 & 1997 & 1998 & 1999 & 2000 & 2001 & 2002\end{array}$

$\begin{array}{ll}\mathbf{5 6} & \text { Other accounts payable } \\ 57 & \text { Trade payables } \\ 58 & \text { Taxes payable } \\ 59 & \text { Other (miscellaneous liabilities) }\end{array}$

Memo:

60 Net lending or borrowing, financial account (lines 30-47)

OTHER CHANGES IN VOLUME ACCOUNT:

61 Total other volume changes

19.7

REVALUATION ACCOUNT:

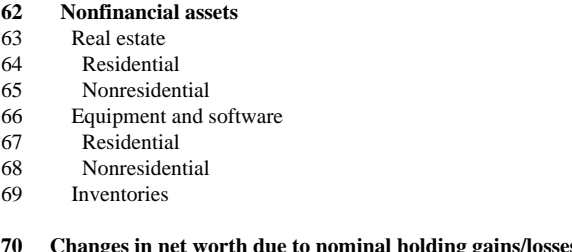

CHANGES IN BALANCE SHEET ACCOUNT:

71 Change in net worth (lines $22+28+61+70$ )

BALANCE SHEET ACCOUNT (end of period):

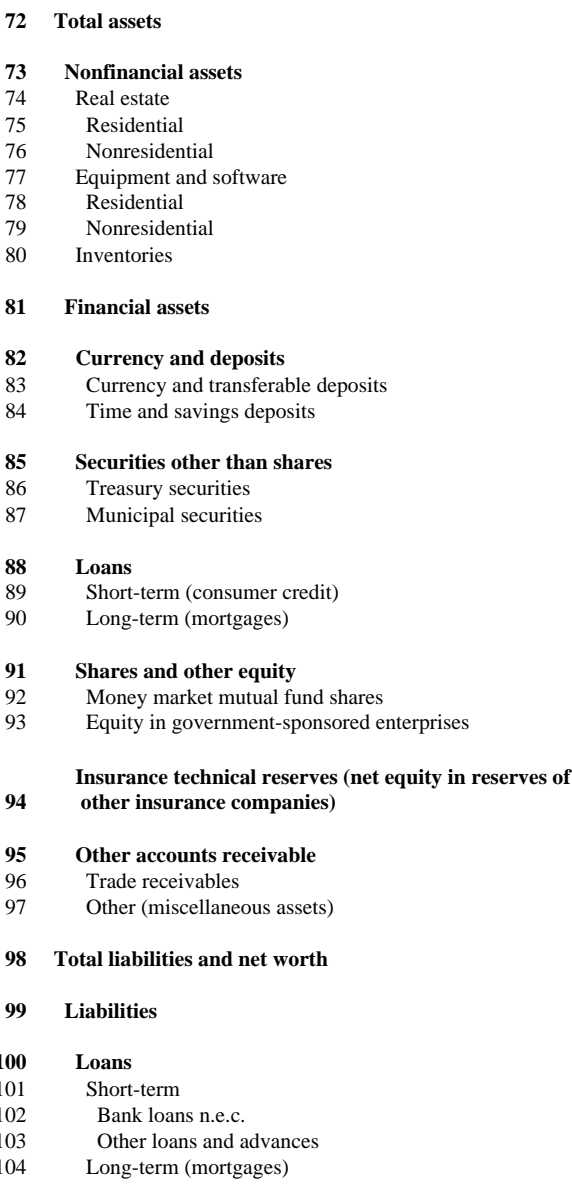

105 Shares and other equity (direct investment in U.S.)

$\begin{array}{rrrrrrrrr}\mathbf{2 7 . 6} & \mathbf{6 3 . 6} & \mathbf{9 2 . 7} & \mathbf{1 2 7 . 8} & \mathbf{1 1 7 . 7} & \mathbf{1 4 5 . 1} & \mathbf{5 1 . 7} & \mathbf{5 0 . 4} & \mathbf{5 6} \\ 13.4 & 31.8 & 32.4 & 31.5 & 35.1 & 47.5 & -7.5 & 21.9 & 57 \\ 0.6 & 2.3 & 4.3 & 4.1 & 8.9 & 11.7 & 4.0 & 8.1 & 58 \\ 13.6 & 29.4 & 56.0 & 92.1 & 73.7 & 85.9 & 55.2 & 20.3 & 59 \\ & & & & & & & & \\ -14.8 & -36.5 & -10.3 & -29.9 & -65.7 & -84.6 & -56.0 & -41.5 & 60\end{array}$

$\begin{array}{rrrrrrrrr}142.0 & 165.7 & 285.1 & 281.6 & 241.1 & 344.8 & 68.9 & 202.6 & 63\end{array}$

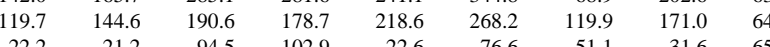

$\begin{array}{lllllllll}22.2 & 21.2 & 94.5 & 102.9 & 22.6 & 76.6 & -51.1 & 31.6 & 65\end{array}$

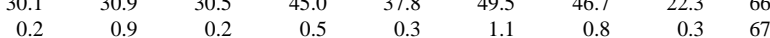

$\begin{array}{rrrrrrrrr}30.0 & 30.0 & 30.3 & 44.4 & 37.5 & 48.4 & 45.8 & 22.0 & 68 \\ 1.2 & -0.0 & -1.4 & -1.6 & 1.1 & 1.4 & -1.8 & 1.3 & 69\end{array}$

$\begin{array}{lllllllll}173.3 & 196.6 & 314.2 & 325.0 & 280.1 & 395.7 & 113.7 & 226.2 & 70\end{array}$

$\begin{array}{lllllllll}193.0 & 175.5 & 249.4 & 248.4 & 207.6 & 368.7 & 92.2 & 190.2 & 71\end{array}$

$\begin{array}{rrrrrrrrr}\mathbf{4 2 0 7 . 2} & \mathbf{4 5 1 4 . 8} & \mathbf{4 9 5 0 . 1} & \mathbf{5 5 0 4 . 9} & \mathbf{6 0 1 9 . 9} & \mathbf{6 7 2 5 . 9} & \mathbf{7 0 2 8 . 5} & \mathbf{7 4 1 6 . 7} & \mathbf{7 2} \\ & & & & & & & & \\ \mathbf{3 6 5 9 . 1} & \mathbf{3 8 7 1 . 7} & \mathbf{4 1 7 6 . 2} & \mathbf{4 5 1 2 . 2} & \mathbf{4 8 4 3 . 1} & \mathbf{5 3 0 3 . 1} & \mathbf{5 4 5 0 . 1} & \mathbf{5 6 9 6 . 9} & \mathbf{7 3} \\ 3215.0 & 3397.9 & 3674.5 & 3949.9 & 4230.5 & 4639.1 & 4751.5 & 4983.8 & 74 \\ 2361.5 & 2522.5 & 2723.5 & 2912.6 & 3157.2 & 3456.3 & 3604.1 & 3811.0 & 75 \\ 853.6 & 875.5 & 951.0 & 1037.3 & 1073.3 & 1182.8 & 1147.4 & 1172.9 & 76 \\ 387.8 & 416.3 & 442.3 & 501.0 & 546.7 & 593.8 & 632.0 & 644.8 & 77 \\ 37.1 & 39.0 & 39.9 & 41.3 & 42.8 & 45.2 & 47.0 & 48.1 & 78 \\ 350.7 & 377.3 & 402.3 & 459.7 & 503.9 & 548.7 & 585.0 & 596.7 & 79 \\ 56.3 & 57.4 & 59.5 & 61.3 & 65.9 & 70.2 & 66.6 & 68.3 & 80 \\ & & & & & & & & \\ \mathbf{5 4 8 . 1} & \mathbf{6 4 3 . 2} & \mathbf{7 7 3 . 8} & \mathbf{9 9 2 . 7} & \mathbf{1 1 7 6 . 8} & \mathbf{1 4 2 2 . 7} & \mathbf{1 5 7 8 . 4} & \mathbf{1 7 1 9 . 8} & \mathbf{8 1} \\ & & & & & & & & \\ \mathbf{1 7 6 . 2} & \mathbf{1 9 9 . 0} & \mathbf{2 3 2 . 0} & \mathbf{2 7 7 . 4} & \mathbf{3 3 5 . 1} & \mathbf{4 1 1 . 6} & \mathbf{4 1 9 . 3} & \mathbf{4 3 4 . 2} & \mathbf{8 2} \\ 104.7 & 124.0 & 146.2 & 178.9 & 217.6 & 274.1 & 274.5 & 287.3 & 83 \\ 71.5 & 75.0 & 85.7 & 98.5 & 117.5 & 137.6 & 144.7 & 146.9 & 84 \\ & & & & & & & & \\ \mathbf{2 5 . 8} & \mathbf{3 1 . 2} & \mathbf{3 5 . 4} & \mathbf{4 0 . 8} & \mathbf{3 9 . 9} & \mathbf{4 2 . 6} & \mathbf{4 6 . 3} & \mathbf{4 8 . 9} & \mathbf{8 5} \\ 23.6 & 28.6 & 32.2 & 38.0 & 37.2 & 40.2 & 42.8 & 45.2 & 86 \\ 2.2 & 2.6 & 3.2 & 2.8 & 2.7 & 2.4 & 3.5 & 3.7 & 87 \\ & & & & & & & & \\ \mathbf{2 1 . 7} & \mathbf{2 0 . 4} & \mathbf{1 8 . 7} & \mathbf{2 6 . 7} & \mathbf{2 4 . 7} & \mathbf{2 3 . 3} & \mathbf{2 6 . 6} & \mathbf{2 7 . 8} & \mathbf{8 8} \\ 0 & 0 & 0 & 0 & 0 & 0 & 0 & 0 & 89 \\ 21.7 & 20.4 & 18.7 & 26.7 & 24.7 & 23.3 & 26.6 & 27.8 & 90 \\ & & & & & & & & \\ \mathbf{1 8 . 0} & \mathbf{2 0 . 9} & \mathbf{2 4 . 6} & \mathbf{3 4 . 2} & \mathbf{4 2 . 3} & \mathbf{5 1 . 0} & \mathbf{6 0 . 5} & \mathbf{6 2 . 9} & \mathbf{9 1} \\ 17.0 & 19.2 & 22.9 & 32.6 & 40.7 & 49.4 & 59.0 & 61.3 & 92 \\ 1.0 & 1.7 & 1.7 & 1.6 & 1.6 & 1.6 & 1.5 & 1.5 & 93 \\ & & & & & & & & \end{array}$

$\begin{array}{rrrrrrrrr}\mathbf{4 4 . 2} & \mathbf{4 4 . 8} & \mathbf{4 5 . 2} & \mathbf{4 5 . 6} & \mathbf{4 5 . 9} & \mathbf{4 5 . 8} & \mathbf{4 8 . 3} & \mathbf{5 2 . 5} & \mathbf{9 4} \\ & & & & & & & & \\ \mathbf{2 6 2 . 2} & \mathbf{3 2 6 . 9} & \mathbf{4 1 7 . 9} & \mathbf{5 6 8 . 0} & \mathbf{6 8 8 . 8} & \mathbf{8 4 8 . 4} & \mathbf{9 7 7 . 4} & \mathbf{1 0 9 3 . 6} & \mathbf{9 5} \\ 140.3 & 169.8 & 204.9 & 233.1 & 272.6 & 342.1 & 343.9 & 366.7 & 96 \\ 121.9 & 157.1 & 213.0 & 334.9 & 416.3 & 506.2 & 633.5 & 726.9 & 97 \\ & & & & & & & & \\ \mathbf{4 2 0 7 . 2} & \mathbf{4 5 1 4 . 8} & \mathbf{4 9 5 0 . 1} & \mathbf{5 5 0 4 . 9} & \mathbf{6 0 1 9 . 9} & \mathbf{6 7 2 5 . 9} & \mathbf{7 0 2 8 . 5} & \mathbf{7 4 1 6 . 7} & \mathbf{9 8} \\ & & & & & & & & \\ \mathbf{1 3 9 6 . 4} & \mathbf{1 5 2 8 . 6} & \mathbf{1 7 1 4 . 5} & \mathbf{2 0 2 0 . 9} & \mathbf{2 3 2 8 . 3} & \mathbf{2 6 6 5 . 5} & \mathbf{2 8 7 6 . 0} & \mathbf{3 0 7 3 . 9} & \mathbf{9 9} \\ & & & & & & & & \\ \mathbf{1 0 6 2 . 0} & \mathbf{1 1 3 0 . 7} & \mathbf{1 2 2 5 . 4} & \mathbf{1 4 0 5 . 3} & \mathbf{1 5 9 5 . 5} & \mathbf{1 7 8 8 . 4} & \mathbf{1 9 4 4 . 7} & \mathbf{2 0 9 3 . 0} & \mathbf{1 0 0} \\ 257.0 & 287.4 & 334.5 & 370.2 & 425.3 & 480.7 & 515.9 & 531.7 & 101 \\ 164.7 & 193.6 & 237.3 & 262.1 & 308.6 & 352.9 & 390.7 & 404.1 & 102 \\ 92.3 & 93.9 & 97.2 & 108.1 & 116.7 & 127.8 & 125.3 & 127.6 & 103 \\ 805.0 & 843.2 & 890.9 & 1035.1 & 1170.1 & 1307.6 & 1428.8 & 1561.3 & 104\end{array}$




\section{Nonfinancial Noncorporate Business}

Billions of dollars

\begin{tabular}{|c|c|c|c|c|c|c|c|c|c|c|}
\hline & & 1995 & 1996 & 1997 & 1998 & 1999 & 2000 & 2001 & 2002 & \\
\hline 106 & Other accounts payable & 331.6 & 393.9 & 485.2 & 612.2 & 729.5 & 873.8 & 928.0 & 977.5 & 106 \\
\hline 107 & Trade payables & 86.2 & 116.8 & 147.8 & 178.6 & 213.3 & 259.9 & 255.0 & 276.0 & 107 \\
\hline 110 & Net worth & 2810.8 & 2986.2 & 3235.6 & 3484.0 & 3691.6 & 4060.3 & 4152.5 & 4342.8 & 110 \\
\hline
\end{tabular}




\section{CURRENT ACCOUNT:}

1 Gross domestic product(GDP)/Gross value added

2 Less consumption of fixed capital

Equals net domestic product/Net value added

Compensation of employees (paid)

Wages and salarie

Employers' social contributions

Taxes on production and imports less subsidies

Operating surplus, net

9 Net national income/Balance of primary incomes, net

Operating surplus, net

Property income (received)

Interest

Distributed income of corporations (dividends)

Reinvested earnings on foreign direct investment

Less uses of property income (paid)

Interest

Distributed income of corporations (dividends)

Reinvested earnings on foreign direct investment

Rent

2 Net national income/Balance of primary incomes, net

21 Less current taxes on income, wealth, etc. (paid)

22 Less other current transfers (paid)

23 Equals disposable income, net

24 Equals net saving

\section{CAPITAL ACCOUNT:}

25 Net saving and capital transfers

6 Net saving

Capital transfers received (net)

8 Capital formation, net

Gross fixed capital formation (acq. of produced nonfinancial assets)

Less consumption of fixed capital

Acq. of nonproduced nonfinancial assets

Inventory change including inventory valuation adjustment

33 Net lending or borrowing, capital account (lines 25-28)

\section{FINANCIAL ACCOUNT:}

34 Net lending or borrowing, capital account (line 33)

35 Net acquisition of financial assets

36 Currency and deposits

37 Currency and transferable deposits

38 Time and savings deposits

39 Foreign deposits

Securities other than shares

Open market paper

Treasury securities

Agency- and GSE-backed securities

Municipal securities

Loans

46 Short-term (security RPs and consumer credit)

47 Long-term (mortgages)

48 Shares and other equity

49 Mutual fund shares

Money market mutual fund shares

U.S. direct investment abroad

U.S. direct investment abroad
Equity in government-sponsored enterprises

53 Investment in finance company subsidiarie

Insurance technical reserves (net equity in reserves of

54 other insurance companies)

55 Other accounts receivable

56 Trade receivables

57 Other (miscellaneous assets)

$\begin{array}{rrrrrrrrr}\mathbf{3 8 7 9 . 5} & \mathbf{4 1 0 9 . 5} & \mathbf{4 4 0 1 . 8} & \mathbf{4 6 5 5 . 0} & \mathbf{4 9 5 0 . 8} & \mathbf{5 2 7 2 . 2} & \mathbf{5 2 9 9 . 3} & \mathbf{5 4 1 0 . 6} & \mathbf{1} \\ & & & & & & & & \\ \mathbf{4 1 5 . 0} & \mathbf{4 3 6 . 5} & \mathbf{4 6 7 . 1} & \mathbf{4 9 3 . 3} & \mathbf{5 2 3 . 8} & \mathbf{5 6 7 . 8} & \mathbf{6 1 0 . 5} & \mathbf{6 1 8 . 2} & \mathbf{2} \\ & & & & & & & & \\ \mathbf{3 4 6 4 . 5} & \mathbf{3 6 7 3 . 0} & \mathbf{3 9 3 4 . 7} & \mathbf{4 1 6 1 . 7} & \mathbf{4 4 2 7 . 0} & \mathbf{4 7 0 4 . 3} & \mathbf{4 6 8 8 . 9} & \mathbf{4 7 9 2 . 4} & \mathbf{3} \\ 2509.8 & 2630.8 & 2812.9 & 3045.6 & 3267.7 & 3544.4 & 3597.0 & 3570.1 & 4 \\ 2076.7 & 2197.0 & 2367.9 & 2567.2 & 2758.0 & 2989.8 & 3016.7 & 2971.8 & 5 \\ 433.1 & 433.8 & 445.1 & 478.4 & 509.7 & 554.5 & 580.4 & 598.3 & 6 \\ 356.9 & 369.1 & 385.5 & 398.7 & 416.6 & 443.4 & 440.3 & 464.5 & 7 \\ 597.8 & 673.1 & 736.3 & 717.4 & 742.7 & 716.5 & 651.5 & 757.7 & 8 \\ & & & & & & & & \\ \mathbf{3 5 7 . 7} & \mathbf{4 1 7 . 9} & \mathbf{4 4 9 . 6} & \mathbf{3 8 5 . 1} & \mathbf{4 2 6 . 9} & \mathbf{3 7 3 . 8} & \mathbf{3 0 3 . 2} & \mathbf{3 8 8 . 7} & \mathbf{9} \\ 597.8 & 673.1 & 736.3 & 717.4 & 742.7 & 716.5 & 651.5 & 757.7 & 10 \\ 295.8 & 331.0 & 367.8 & 349.3 & 384.0 & 453.6 & 413.5 & 398.0 & 11 \\ 189.9 & 216.7 & 239.5 & 235.9 & 251.3 & 291.3 & 273.0 & 242.9 & 12 \\ 45.4 & 52.8 & 62.4 & 58.2 & 59.7 & 62.0 & 57.1 & 54.8 & 13 \\ 60.5 & 61.5 & 65.9 & 55.2 & 73.0 & 100.3 & 83.4 & 100.3 & 14 \\ 535.9 & 586.2 & 654.5 & 681.6 & 699.8 & 796.3 & 761.8 & 767.0 & 15 \\ 298.0 & 319.9 & 354.2 & 371.3 & 402.9 & 471.5 & 465.3 & 437.7 & 16 \\ 223.4 & 250.2 & 278.3 & 299.2 & 284.4 & 313.4 & 305.3 & 312.0 & 17 \\ 7.5 & 7.5 & 12.8 & 2.7 & 3.9 & 0 & -22.3 & 5.2 & 18 \\ 7.0 & 8.6 & 9.2 & 8.4 & 8.6 & 11.4 & 13.5 & 12.1 & 19 \\ & & & & & & & & \\ \mathbf{3 5 7 . 7} & \mathbf{4 1 7 . 9} & \mathbf{4 4 9 . 6} & \mathbf{3 8 5 . 1} & \mathbf{4 2 6 . 9} & \mathbf{3 7 3 . 8} & \mathbf{3 0 3 . 2} & \mathbf{3 8 8 . 7} & \mathbf{2 0} \\ 141.0 & 153.1 & 161.9 & 158.6 & 171.2 & 170.2 & 134.3 & 131.9 & 21 \\ 30.2 & 38.0 & 39.0 & 35.2 & 45.0 & 48.4 & 50.0 & 59.1 & 22 \\ & & & & & & & & \\ \mathbf{1 8 6 . 5} & \mathbf{2 2 6 . 8} & \mathbf{2 4 8 . 7} & \mathbf{1 9 1 . 3} & \mathbf{2 1 0 . 7} & \mathbf{1 5 5 . 2} & \mathbf{1 1 8 . 9} & \mathbf{1 9 7 . 7} & \mathbf{2 3} \\ \mathbf{1 8 6 . 5} & \mathbf{2 2 6 . 8} & \mathbf{2 4 8 . 7} & \mathbf{1 9 1 . 3} & \mathbf{2 1 0 . 7} & \mathbf{1 5 5 . 2} & \mathbf{1 1 8 . 9} & \mathbf{1 9 7 . 7} & \mathbf{2 4}\end{array}$

$\begin{array}{rrrrrrrrr}\mathbf{1 8 6 . 5} & \mathbf{2 2 6 . 6} & \mathbf{2 4 8 . 7} & \mathbf{1 9 1 . 1} & \mathbf{2 1 0 . 8} & \mathbf{1 5 5 . 2} & \mathbf{1 1 8 . 8} & \mathbf{1 9 7 . 7} & \mathbf{2 5} \\ 186.5 & 226.8 & 248.7 & 191.3 & 210.7 & 155.2 & 118.9 & 197.7 & 26 \\ 0 & 0 & 0 & 0 & 0 & 0 & 0 & 0 & 27 \\ & & & & & & & & \\ \mathbf{2 2 3 . 2} & \mathbf{2 1 7 . 8} & \mathbf{2 8 4 . 7} & \mathbf{2 8 0 . 5} & \mathbf{3 3 5 . 1} & \mathbf{3 6 0 . 7} & \mathbf{1 9 4 . 1} & \mathbf{1 5 2 . 5} & \mathbf{2 8} \\ 597.5 & 635.4 & 684.6 & 709.7 & 800.5 & 882.1 & 847.0 & 771.2 & 29 \\ 415.0 & 436.5 & 467.1 & 493.3 & 523.9 & 567.9 & 610.5 & 618.2 & 30 \\ 0.6 & -2.2 & 1.8 & -1.9 & -7.7 & -8.5 & -8.0 & -8.8 & 31 \\ 40.1 & 21.0 & 65.3 & 65.9 & 66.1 & 54.9 & -34.4 & 8.3 & 32 \\ & & & & & & & & \\ \mathbf{- 3 6 . 7} & \mathbf{8 . 8} & \mathbf{- 3 6 . 0} & \mathbf{- 8 9 . 4} & \mathbf{- 1 2 4 . 3} & \mathbf{- 2 0 5 . 5} & \mathbf{- 7 5 . 3} & \mathbf{4 5 . 2} & \mathbf{3 3}\end{array}$

$\begin{array}{rrrrrrrrr}\mathbf{- 3 6 . 7} & \mathbf{8 . 8} & \mathbf{- 3 6 . 0} & \mathbf{- 8 9 . 4} & \mathbf{- 1 2 4 . 3} & \mathbf{- 2 0 5 . 5} & \mathbf{- 7 5 . 3} & \mathbf{4 5 . 2} & \mathbf{3 4} \\ & & & & & & & & \\ \mathbf{4 2 6 . 4} & \mathbf{4 5 4 . 0} & \mathbf{2 7 2 . 4} & \mathbf{5 6 9 . 9} & \mathbf{9 6 9 . 9} & \mathbf{1 2 0 9 . 2} & \mathbf{1 7 7 . 6} & \mathbf{1 2 1 . 3} & \mathbf{3 5} \\ & & & & & & & & \\ \mathbf{9 . 5} & \mathbf{5 0 . 1} & \mathbf{2 2 . 2} & \mathbf{2 3 . 6} & \mathbf{8 1 . 2} & \mathbf{4 3 . 5} & \mathbf{- 6 4 . 2} & \mathbf{1 0 . 4} & \mathbf{3 6} \\ 4.5 & 39.3 & 7.6 & 23.0 & 56.0 & 50.5 & -49.5 & 9.5 & 37 \\ 3.3 & -0.0 & 19.7 & -6.8 & 24.3 & 0.5 & -6.2 & -3.6 & 38 \\ 1.7 & 10.8 & -5.1 & 7.4 & 0.9 & -7.4 & -8.5 & 4.4 & 39 \\ & & & & & & & & \\ \mathbf{- 8 . 8} & \mathbf{0 . 7} & \mathbf{- 3 9 . 8} & \mathbf{1 . 1} & \mathbf{5 . 0} & \mathbf{1 8 . 8} & \mathbf{- 0 . 1} & \mathbf{2 1 . 4} & \mathbf{4 0} \\ 1.3 & 11.4 & 4.6 & 3.3 & 8.2 & 10.2 & 2.4 & 4.5 & 41 \\ 6.3 & -10.0 & -20.2 & -3.2 & -4.2 & -1.3 & -1.6 & 14.8 & 42 \\ 3.5 & 5.1 & -20.5 & 2.6 & 1.8 & 3.0 & 1.7 & -1.2 & 43 \\ -19.9 & -5.8 & -3.6 & -1.6 & -0.7 & 6.9 & -2.6 & 3.3 & 44 \\ & & & & & & & & \\ \mathbf{0 . 3} & \mathbf{- 9 . 4} & \mathbf{2 7 . 7} & \mathbf{- 1 6 . 1} & \mathbf{- 2 2 . 0} & \mathbf{4 . 7} & \mathbf{2 . 5} & \mathbf{4 . 1} & \mathbf{4 5} \\ -1.3 & -5.9 & 1.8 & -3.1 & 4.1 & 2.4 & -0.6 & 2.1 & 46 \\ 1.6 & -3.6 & 25.9 & -13.0 & -26.0 & 2.3 & 3.1 & 2.0 & 47 \\ & & & & & & & & \\ \mathbf{1 2 2 . 5} & \mathbf{9 5 . 0} & \mathbf{9 4 . 3} & \mathbf{1 6 8 . 1} & \mathbf{2 5 7 . 0} & \mathbf{1 8 4 . 3} & \mathbf{2 0 7 . 9} & \mathbf{1 4 8 . 9} & \mathbf{4 8} \\ 4.6 & 8.7 & -6.4 & 6.7 & 7.4 & 12.0 & 2.0 & 10.5 & 49 \\ 22.9 & 7.7 & 20.2 & 38.6 & 28.4 & 36.5 & 110.5 & 26.9 & 50 \\ 90.3 & 76.8 & 84.3 & 129.2 & 194.4 & 128.4 & 97.0 & 117.0 & 51 \\ 0 & 0 & 0 & 0 & 0 & 0 & 0 & 0 & 52 \\ 4.6 & 1.8 & -3.7 & -6.4 & 26.8 & 7.4 & -1.7 & -5.5 & 53 \\ & & & & & & & & \\ \mathbf{8 . 2} & \mathbf{2 . 6} & \mathbf{1 . 9} & \mathbf{1 . 7} & \mathbf{1 . 0} & \mathbf{- 0 . 3} & \mathbf{1 0 . 3} & \mathbf{1 7 . 4} & \mathbf{5 4} \\ \mathbf{2 9 4 . 7} & \mathbf{3 1 5 . 2} & \mathbf{1 6 6 . 0} & \mathbf{3 9 1 . 5} & \mathbf{6 4 7 . 6} & \mathbf{9 5 8 . 2} & \mathbf{2 1 . 3} & \mathbf{- 8 0 . 8} & \mathbf{5 5} \\ 78.0 & 88.1 & 93.5 & 85.0 & 203.4 & 283.0 & -129.4 & -34.4 & 56 \\ 216.7 & 227.1 & 72.5 & 306.5 & 444.1 & 675.2 & 150.7 & -46.4 & 57\end{array}$




\begin{tabular}{|c|c|c|c|c|c|c|c|c|c|c|}
\hline & & 1995 & 1996 & 1997 & 1998 & 1999 & 2000 & 2001 & 2002 & \\
\hline 58 & Net incurrence of liabilities & 390.8 & 398.5 & 283.5 & 616.0 & 987.6 & 1237.4 & 95.2 & 107.0 & 58 \\
\hline 59 & Securities other than shares & 112.3 & 118.4 & 168.4 & 265.3 & 264.1 & 212.0 & 263.7 & 71.2 & 59 \\
\hline 60 & Open market paper & 18.1 & -0.9 & 13.7 & 24.4 & 37.4 & 48.1 & -88.3 & -64.2 & 60 \\
\hline 61 & Municipal securities & 3.1 & 3.1 & 4.2 & 5.8 & 5.1 & 1.4 & 3.5 & 3.1 & 61 \\
\hline 62 & Corporate bonds & 91.1 & 116.3 & 150.5 & 235.2 & 221.7 & 162.6 & 348.5 & 132.3 & 62 \\
\hline 63 & Loans & 114.8 & 64.4 & 123.4 & 127.1 & 108.4 & 145.2 & -36.4 & -30.2 & 63 \\
\hline 64 & Short-term & 106.8 & 54.6 & 90.9 & 130.5 & 67.6 & 114.0 & -95.5 & -80.5 & 64 \\
\hline 65 & Bank loans n.e.c. & 74.5 & 40.4 & 51.1 & 76.2 & 44.1 & 48.0 & -103.3 & -96.5 & 65 \\
\hline 66 & Other loans and advances & 32.3 & 14.2 & 39.8 & 54.3 & 23.4 & 65.9 & 7.8 & 16.0 & 66 \\
\hline 67 & Long-term (mortgages) & 8.0 & 9.8 & 32.5 & -3.3 & 40.8 & 31.2 & 59.0 & 50.2 & 67 \\
\hline 68 & Shares and other equity & -4.8 & 24.3 & 22.8 & -71.1 & 136.7 & 62.9 & 24.0 & -18.9 & 68 \\
\hline 69 & Corporate equities & -58.3 & -47.3 & -77.4 & -215.5 & -110.4 & -118.2 & -47.4 & -41.6 & 69 \\
\hline 70 & Direct investment in U.S. & 53.6 & 71.7 & 100.2 & 144.4 & 247.0 & 181.1 & 71.4 & 22.7 & 70 \\
\hline 71 & Insurance technical reserves (contributions payable) & 4.1 & 4.1 & 7.1 & 21.4 & -7.6 & 1.2 & 1.3 & 1.3 & 71 \\
\hline 72 & Other accounts payable & 164.4 & 187.3 & -38.3 & 273.3 & 486.1 & 816.0 & -157.3 & 83.7 & 72 \\
\hline 73 & Trade payables & 81.0 & 49.5 & 65.1 & 57.6 & 178.5 & 313.3 & -103.7 & -15.8 & 73 \\
\hline 74 & Other & 83.5 & 137.8 & -103.3 & 215.7 & 307.6 & 502.8 & -53.6 & 99.5 & 74 \\
\hline 75 & Taxes payable & -0.0 & 9.6 & 9.3 & 4.8 & 7.0 & 7.0 & 3.1 & 11.9 & 75 \\
\hline 76 & Miscellaneous liabilities & 83.5 & 128.3 & -112.7 & 210.8 & 300.6 & 495.8 & -56.6 & 87.6 & 76 \\
\hline \multicolumn{11}{|c|}{ Memo: } \\
\hline 77 & Net lending or borrowing, financial account (lines 35-58) & 35.5 & 55.5 & -11.1 & -46.1 & -17.7 & -28.2 & 82.4 & 14.4 & 77 \\
\hline \multicolumn{11}{|c|}{ OTHER CHANGES IN VOLUME ACCOUNT: } \\
\hline 78 & Total other volume changes & 177.3 & 125.5 & 128.0 & 438.5 & 491.4 & 651.4 & 26.4 & 7.3 & 78 \\
\hline 79 & Other volume changes & 86.8 & 81.8 & 117.2 & 415.4 & 385.8 & 460.0 & -122.2 & 35.9 & 79 \\
\hline 80 & Less statistical discrepancy (lines 33-[35-58])* & -72.3 & -46.7 & -24.9 & -43.3 & -106.6 & -177.3 & -157.8 & 30.8 & 80 \\
\hline 81 & Less inventory valuation adjustment & -18.3 & 3.1 & 14.1 & 20.2 & 0.9 & -14.1 & 9.1 & -2.2 & 81 \\
\hline \multicolumn{11}{|c|}{ REVALUATION ACCOUNT: } \\
\hline 82 & Nonfinancial assets & 110.2 & 74.4 & 308.6 & 355.9 & 106.4 & 315.9 & -227.1 & 136.6 & 82 \\
\hline 83 & Real estate & 82.4 & 77.9 & 348.9 & 393.2 & 93.3 & 306.2 & -186.7 & 134.4 & 83 \\
\hline 84 & Equipment and software & 23.4 & -6.5 & -28.0 & -27.2 & -8.7 & -2.8 & -14.9 & -19.8 & 84 \\
\hline 85 & Inventories & 4.4 & 2.9 & -12.3 & -10.2 & 21.8 & 12.5 & -25.5 & 22.0 & 85 \\
\hline 86 & Financial assets & 12.7 & 19.6 & 0.7 & -5.0 & 13.9 & -50.8 & -62.7 & -15.0 & 86 \\
\hline 87 & Mutual fund shares & 10.0 & 8.6 & 18.4 & 16.3 & 21.6 & -15.0 & -15.0 & -24.5 & 87 \\
\hline 88 & Direct investment abroad & 2.8 & 11.0 & -17.6 & -21.3 & -7.8 & -35.7 & -47.8 & 9.5 & 88 \\
\hline 89 & Liabilities & 1670.9 & 1258.0 & 2155.9 & 2025.2 & 3634.1 & -2558.7 & -1904.1 & -2757.9 & 89 \\
\hline 90 & Corporate equity & 1675.6 & 1272.4 & 2203.9 & 2027.7 & 3688.2 & -2358.6 & -1835.2 & -2847.7 & 90 \\
\hline 91 & Direct investment in U.S. & -4.7 & -14.5 & -48.0 & -2.4 & -54.1 & -200.1 & -68.9 & 89.8 & 91 \\
\hline 92 & Changes in net worth due to nominal holding gains/losses & -1547.9 & -1164.0 & -1846.6 & -1674.3 & -3513.9 & 2823.8 & 1614.3 & 2879.4 & 92 \\
\hline \multicolumn{11}{|c|}{ CHANGES IN BALANCE SHEET ACCOUNT: } \\
\hline 93 & Change in net worth (lines $28+33+78+92$ ) & -1184.1 & -811.7 & -1469.9 & -1044.5 & $-\mathbf{2 8 1 1 . 7}$ & 3630.4 & 1759.6 & 3084.4 & 93 \\
\hline \multicolumn{11}{|c|}{ BALANCE SHEET ACCOUNT (end of period): } \\
\hline 94 & Total assets & 11580.7 & 12363.1 & 13269.9 & 14866.4 & 16582.1 & 18939.8 & 19014.9 & 19345.5 & 94 \\
\hline 95 & Nonfinancial assets & 6622.2 & 6905.4 & 7461.2 & 8050.2 & 8488.3 & 9167.3 & 9116.0 & 9412.4 & 95 \\
\hline 96 & Real estate & 3125.1 & 3265.2 & 3665.8 & 4108.9 & 4283.8 & 4671.2 & 4573.0 & 4770.5 & 96 \\
\hline 97 & Equipment and software & 2376.0 & 2496.0 & 2614.1 & 2722.7 & 2891.2 & 3092.8 & 3200.7 & 3258.3 & 97 \\
\hline 98 & Inventories & 1069.8 & 1090.7 & 1129.6 & 1165.2 & 1252.1 & 1333.6 & 1264.5 & 1297.0 & 98 \\
\hline 99 & Nonproduced nonfinancial assets & 51.3 & 53.5 & 51.6 & 53.5 & 61.2 & 69.7 & 77.7 & 86.5 & 99 \\
\hline 100 & Financial assets & 4958.5 & $\mathbf{5 4 5 7 . 7}$ & 5808.7 & 6816.1 & 8093.8 & 9772.5 & 9898.9 & 9933.1 & 100 \\
\hline 101 & Currency and deposits & 322.2 & 372.2 & 394.4 & 418.1 & 499.3 & 542.8 & 478.6 & 488.9 & 101 \\
\hline 102 & Currency and transferable deposits & 205.1 & 244.3 & 251.9 & 275.0 & 331.0 & 381.4 & 331.9 & 341.4 & 102 \\
\hline 103 & Time and savings deposits & 99.7 & 99.7 & 119.4 & 112.6 & 136.9 & 137.3 & 131.1 & 127.5 & 103 \\
\hline 104 & Foreign deposits & 17.4 & 28.2 & 23.1 & 30.5 & 31.5 & 24.0 & 15.5 & 20.0 & 104 \\
\hline 105 & Securities other than shares & 137.4 & 138.1 & 98.3 & 99.4 & 104.4 & 123.2 & 123.2 & 144.5 & 105 \\
\hline 106 & Open market paper & 20.1 & 31.5 & 36.1 & 39.4 & 47.6 & 57.8 & 60.2 & 64.7 & 106 \\
\hline 107 & Treasury securities & 57.1 & 47.1 & 26.8 & 23.6 & 19.4 & 18.1 & 16.5 & 31.3 & 107 \\
\hline 108 & Agency- and GSE-backed securities & 23.4 & 28.5 & 8.0 & 10.6 & 12.4 & 15.4 & 17.2 & 15.9 & 108 \\
\hline 109 & Municipal securities & 36.8 & 31.0 & 27.4 & 25.7 & 25.0 & 31.9 & 29.3 & 32.6 & 109 \\
\hline
\end{tabular}




\section{Nonfinancial Corporate Business}

Billions of dollars

\begin{tabular}{|c|c|c|c|c|c|c|c|c|c|c|}
\hline & & 1995 & 1996 & 1997 & 1998 & 1999 & 2000 & 2001 & 2002 & \\
\hline 110 & Loans & 145.4 & 136.0 & 163.7 & 147.7 & 125.7 & 130.4 & 132.9 & 137.0 & 110 \\
\hline 111 & Short-term & 87.5 & 81.7 & 83.5 & 80.4 & 84.5 & 86.9 & 86.3 & 88.4 & 111 \\
\hline 112 & Security RPs & 2.4 & 3.9 & 4.6 & 4.2 & 5.8 & 4.2 & 4.0 & 6.2 & 112 \\
\hline 113 & Consumer credit & 85.1 & 77.7 & 78.9 & 76.2 & 78.7 & 82.7 & 82.3 & 82.2 & 113 \\
\hline 114 & Long-term (mortgages) & 57.9 & 54.4 & 80.2 & 67.3 & 41.2 & 43.5 & 46.6 & 48.7 & 114 \\
\hline 115 & Shares and other equity & 909.8 & 1024.4 & 1119.5 & 1282.6 & 1553.5 & 1687.0 & 1832.1 & 1966.0 & 115 \\
\hline 116 & Mutual fund shares & 45.7 & 63.0 & 75.0 & 98.0 & 127.0 & 124.0 & 111.0 & 97.0 & 116 \\
\hline 117 & Money market mutual fund shares & 60.0 & 67.6 & 87.8 & 126.4 & 154.9 & 191.4 & 301.9 & 328.8 & 117 \\
\hline 118 & U.S. direct investment abroad & 778.7 & 866.5 & 933.1 & 1041.0 & 1227.7 & 1320.4 & 1369.6 & 1496.1 & 118 \\
\hline 119 & Equity in government-sponsored enterprises & 0 & 0 & 0 & 0 & 0 & 0 & 0 & 0 & 119 \\
\hline 120 & Investment in finance company subsidiaries & 25.5 & 27.3 & 23.5 & 17.1 & 43.9 & 51.3 & 49.6 & 44.1 & 120 \\
\hline 121 & $\begin{array}{l}\text { Insurance technical reserves (net equity in reserves of } \\
\text { other insurance companies) }\end{array}$ & 183.6 & 186.2 & 188.1 & 189.8 & 190.8 & 190.4 & 200.8 & 218.2 & 121 \\
\hline 122 & Other accounts receivable & 3260.0 & 3600.8 & 3844.6 & 4678.6 & 5620.1 & 7098.6 & 7131.4 & 6978.4 & 122 \\
\hline 123 & Trade receivables & 1184.9 & 1273.1 & 1366.6 & 1451.6 & 1655.0 & 1938.1 & 1808.7 & 1774.3 & 123 \\
\hline 124 & Other (miscellaneous assets) & 2075.1 & 2327.7 & 2478.0 & 3227.0 & 3965.1 & 5160.5 & 5322.7 & 5204.1 & 124 \\
\hline 125 & Total liabilities and net worth & 11580.7 & 12363.1 & 13269.9 & 14866.4 & 16582.1 & 18939.8 & 19014.9 & 19345.5 & 125 \\
\hline 126 & Liabilities & 12423.6 & 14017.7 & 16394.4 & 19035.4 & 23562.9 & 22290.2 & 20605.6 & 17851.8 & 126 \\
\hline 127 & Securities other than shares & 1636.2 & 1754.6 & 1921.5 & 2186.8 & 2450.9 & 2662.9 & 2926.6 & 2997.8 & 127 \\
\hline 128 & Open market paper & 157.4 & 156.4 & 168.6 & 193.0 & 230.3 & 278.4 & 190.1 & 126.0 & 128 \\
\hline 129 & Municipal securities & 134.8 & 137.9 & 142.0 & 147.8 & 152.8 & 154.2 & 157.7 & 160.8 & 129 \\
\hline 130 & Corporate bonds & 1344.1 & 1460.4 & 1610.9 & 1846.0 & 2067.7 & 2230.3 & 2578.8 & 2711.0 & 130 \\
\hline 131 & Loans & 1273.4 & 1337.7 & 1460.9 & 1588.0 & 1730.7 & 1875.9 & 1840.1 & 1809.8 & 131 \\
\hline 132 & Short-term & 1055.4 & 1110.0 & 1200.4 & 1330.8 & 1398.4 & 1512.3 & 1417.5 & 1337.0 & 132 \\
\hline 133 & Bank loans n.e.c. & 601.8 & 642.1 & 692.7 & 768.8 & 813.0 & 861.0 & 758.3 & 661.9 & 133 \\
\hline 134 & Other loans and advances & 453.7 & 467.9 & 507.7 & 562.0 & 585.4 & 651.3 & 659.1 & 675.1 & 134 \\
\hline 135 & Long-term (mortgages) & 217.9 & 227.7 & 260.5 & 257.2 & 332.3 & 363.5 & 422.6 & 472.8 & 135 \\
\hline 136 & Shares and other equity & 7055.2 & 8337.5 & 10516.3 & 12470.4 & 16241.2 & 13745.4 & 11865.2 & 9088.4 & 136 \\
\hline 137 & Corporate equity & 6414.1 & 7639.2 & 9765.7 & 11577.8 & 15155.6 & 12678.8 & 10796.2 & 7906.9 & 137 \\
\hline 138 & Direct investment in U.S. & 641.1 & 698.4 & 750.6 & 892.6 & 1085.5 & 1066.6 & 1069.1 & 1181.5 & 138 \\
\hline 139 & Insurance technical reserves (contributions payable) & 82.4 & 86.4 & 93.5 & 114.9 & 107.3 & 108.5 & 109.8 & 111.1 & 139 \\
\hline 140 & Other accounts payable & 2376.4 & 2501.4 & 2402.3 & 2675.3 & 3032.8 & 3897.4 & 3864.0 & 3844.7 & 140 \\
\hline 141 & Trade payables & 877.5 & 927.0 & 992.1 & 1049.7 & 1228.2 & 1541.4 & 1437.7 & 1421.9 & 141 \\
\hline 142 & Taxes payable & 40.3 & 49.9 & 59.2 & 64.1 & 71.0 & 78.0 & 81.0 & 93.0 & 142 \\
\hline 143 & Miscellaneous liabilities & 1458.6 & 1524.5 & 1351.0 & 1561.6 & 1733.6 & 2278.0 & 2345.2 & 2329.9 & 143 \\
\hline 144 & Net worth & -842.9 & -1654.6 & -3124.5 & -4169.0 & -6980.8 & -3350.3 & -1590.8 & 1493.6 & 144 \\
\hline
\end{tabular}

* The discrepancy is the difference between net lending or borrowing derived in the capital account and the same concept derived in the financial account. The discrepancy reflects differences in source data, timing of recorded flows, and other statistical differences between the capital and financial accounts. 
6. Financial Business (1)

Billions of dollars

$\begin{array}{llllllll}1995 & 1996 & 1997 & 1998 & 1999 & 2000 & 2001 & 2002\end{array}$

\section{CURRENT ACCOUNT:}

1 Gross domestic product(GDP)/Gross value added

2 Less consumption of fixed capital

Equals net domestic product/Net value added

Compensation of employees (paid)

Wages and salaries

Employers' social contributions

Taxes on production and imports less subsidies

Operating surplus, net

Net national income/Balance of primary incomes, net

Operating surplus, net

Property income (received)

Interest

Distributed income of corporations (dividends)

Reinvested earnings on foreign direct investment

Less uses of property income (paid)

Interest

Distributed income of corporations

Dividends

Withdrawals from income of quasi-corporations

Reinvested earnings on foreign direct investment

Rents

2 Net national income/Balance of primary incomes, net

Less current taxes on income, wealth, etc. (paid)

Less other current transfers (paid)

25 Equals disposable income, net

26 Equals net saving

CAPITAL ACCOUNT:

27 Net saving

28 Capital formation, net

29 Gross fixed capital formation (nonresidential)

30 Less consumption of fixed capital

31 Net lending or borrowing, capital account (lines 27-28)

FINANCIAL ACCOUNT:

\begin{tabular}{ll}
$\mathbf{3 2}$ & Net lending or borrowing (line 31) \\
$\mathbf{3 3}$ & Net acquisition of financial assets \\
$\mathbf{3 4}$ & Monetary gold and SDRs \\
$\mathbf{3 5}$ & Currency and deposits \\
$\mathbf{3 6}$ & Securities other than shares \\
$\mathbf{3 7}$ & Loans \\
38 & Short-term \\
39 & Long-term (mortgages) \\
$\mathbf{4 0}$ & Shares and other equity \\
41 & Corporate equities \\
42 & Mutual fund shares \\
43 & Money market mutual fund shares \\
44 & Equity in government-sponsored enterprises \\
45 & U.S. direct investment abroad \\
46 & Stock in Federal Reserve Banks \\
47 & Investment in subsidiaries \\
$\mathbf{4 8}$ & Insurance technical reserves \\
& \\
$\mathbf{4 9}$ & Other accounts receivable \\
& \\
$\mathbf{5 0}$ & Net incurrence of liabilities \\
$\mathbf{5 1}$ & Currency and deposits \\
$\mathbf{5 2}$ & Securities other than shares \\
$\mathbf{5 3}$ & Loans \\
54 & Short-term \\
\hline
\end{tabular}

$\begin{array}{rrrrrrrrr}\mathbf{5 4 1 . 0} & \mathbf{6 0 1 . 9} & \mathbf{6 7 9 . 2} & \mathbf{7 6 4 . 3} & \mathbf{8 1 3 . 8} & \mathbf{8 9 9 . 8} & \mathbf{9 1 7 . 7} & \mathbf{9 4 9 . 0} & \mathbf{1} \\ & & & & & & & & \\ \mathbf{7 4 . 0} & \mathbf{7 9 . 3} & \mathbf{8 9 . 0} & \mathbf{9 8 . 4} & \mathbf{1 1 1 . 4} & \mathbf{1 2 6 . 1} & \mathbf{1 3 5 . 1} & \mathbf{1 3 3 . 5} & \mathbf{2} \\ & & & & & & & & \\ \mathbf{4 6 7 . 0} & \mathbf{5 2 2 . 6} & \mathbf{5 9 0 . 2} & \mathbf{6 6 5 . 9} & \mathbf{7 0 2 . 4} & \mathbf{7 7 3 . 7} & \mathbf{7 8 2 . 6} & \mathbf{8 1 5 . 5} & \mathbf{3} \\ 282.9 & 305.7 & 334.1 & 376.4 & 403.9 & 443.1 & 450.7 & 447.6 & 4 \\ 238.9 & 260.1 & 285.4 & 322.0 & 345.5 & 379.3 & 384.7 & 379.4 & 5 \\ 44.0 & 45.6 & 48.7 & 54.4 & 58.4 & 63.8 & 66.0 & 68.2 & 6 \\ 31.0 & 33.2 & 36.2 & 37.5 & 40.2 & 41.4 & 41.7 & 44.6 & 7 \\ 153.1 & 183.7 & 219.9 & 252.0 & 258.3 & 289.2 & 290.2 & 323.5 & 8 \\ & & & & & & & & \\ \mathbf{1 2 4 . 3} & \mathbf{1 1 6 . 7} & \mathbf{1 2 1 . 4} & \mathbf{1 2 0 . 9} & \mathbf{1 4 4 . 1} & \mathbf{1 4 3 . 7} & \mathbf{1 8 1 . 3} & \mathbf{1 9 4 . 5} & \mathbf{9} \\ 153.1 & 183.7 & 219.9 & 252.0 & 258.3 & 289.2 & 290.2 & 323.5 & 10 \\ 931.9 & 974.6 & 1078.4 & 1185.9 & 1280.9 & 1542.1 & 1516.8 & 1373.8 & 11 \\ 887.7 & 919.4 & 1014.0 & 1115.1 & 1201.1 & 1456.3 & 1434.7 & 1297.1 & 12 \\ 35.9 & 46.4 & 54.8 & 62.4 & 68.7 & 69.9 & 68.2 & 56.0 & 13 \\ 8.3 & 8.8 & 9.6 & 8.4 & 11.1 & 15.9 & 13.9 & 20.7 & 14 \\ 960.7 & 1041.6 & 1176.9 & 1317.0 & 1395.1 & 1687.6 & 1625.7 & 1502.8 & 15 \\ 844.0 & 886.6 & 998.6 & 1131.1 & 1186.7 & 1445.9 & 1407.2 & 1273.4 & 16 \\ 115.6 & 153.8 & 176.0 & 185.6 & 207.9 & 241.7 & 225.0 & 227.7 & 17 \\ 79.5 & 106.2 & 122.8 & 130.6 & 139.7 & 167.0 & 158.0 & 157.8 & 18 \\ 36.1 & 47.6 & 53.2 & 55.0 & 68.2 & 74.7 & 67.0 & 69.9 & 19 \\ 1.1 & 1.2 & 2.3 & 0.3 & 0.5 & 0 & -6.5 & 1.7 & 20 \\ 0 & 0 & 0 & 0 & 0 & 0 & 0 & 0 & 21 \\ & & & & & & & & \\ \mathbf{1 2 4 . 3} & \mathbf{1 1 6 . 7} & \mathbf{1 2 1 . 4} & \mathbf{1 2 0 . 9} & \mathbf{1 4 4 . 1} & \mathbf{1 4 3 . 7} & \mathbf{1 8 1 . 3} & \mathbf{1 9 4 . 5} & \mathbf{2 2} \\ 77.6 & 78.6 & 84.2 & 89.7 & 87.4 & 94.9 & 66.8 & 63.1 & 23 \\ 9.3 & 7.8 & -1.9 & 20.7 & 12.3 & 29.1 & 37.4 & 18.2 & 24 \\ \mathbf{3 7 . 4} & \mathbf{3 0 . 3} & \mathbf{3 9 . 1} & \mathbf{1 0 . 5} & \mathbf{4 4 . 4} & \mathbf{1 9 . 7} & \mathbf{7 7 . 1} & \mathbf{1 1 3 . 2} & \mathbf{2 5} \\ \mathbf{3 7 . 4} & \mathbf{3 0 . 3} & \mathbf{3 9 . 1} & \mathbf{1 0 . 5} & \mathbf{4 4 . 4} & \mathbf{1 9 . 7} & \mathbf{7 7 . 1} & \mathbf{1 1 3 . 2} & \mathbf{2 6}\end{array}$

$\begin{array}{rrrrrrrrr}37.4 & \mathbf{3 0 . 3} & \mathbf{3 9 . 1} & \mathbf{1 0 . 5} & \mathbf{4 4 . 4} & \mathbf{1 9 . 7} & \mathbf{7 7 . 1} & \mathbf{1 1 3 . 2} & \mathbf{2 7} \\ & & & & & & & & \\ \mathbf{1 4 . 2} & \mathbf{3 2 . 9} & \mathbf{7 6 . 5} & \mathbf{9 0 . 5} & \mathbf{2 8 . 8} & \mathbf{5 . 3} & \mathbf{- 1 2 . 2} & \mathbf{- 1 1 . 3} & \mathbf{2 8} \\ 88.2 & 112.2 & 165.5 & 188.9 & 140.2 & 131.4 & 122.9 & 122.2 & 29 \\ 74.0 & 79.3 & 89.0 & 98.4 & 111.4 & 126.1 & 135.1 & 133.5 & 30 \\ \mathbf{2 3 . 2} & \mathbf{- 2 . 6} & \mathbf{- 3 7 . 4} & \mathbf{- 8 0 . 0} & \mathbf{1 5 . 6} & \mathbf{1 4 . 4} & \mathbf{8 9 . 3} & \mathbf{1 2 4 . 5} & \mathbf{3 1}\end{array}$

\begin{tabular}{|c|c|c|c|c|c|c|c|}
\hline 23.2 & -2.6 & -37.4 & -80.0 & 15.6 & 14.4 & 89.3 & 124.5 \\
\hline 1511.3 & 1512.4 & 1984.0 & 2568.5 & 2467.9 & 2359.4 & 2771.5 & 1987.6 \\
\hline 2.1 & -0.5 & -0.5 & -0.0 & -3.0 & -4.0 & -0.0 & -0.0 \\
\hline 55.8 & 43.7 & 57.1 & 89.4 & 43.8 & 25.0 & 204.7 & 24.4 \\
\hline 543.2 & 399.7 & 717.5 & 876.7 & 927.3 & 632.1 & 1003.4 & 933.4 \\
\hline 583.8 & 554.6 & 639.6 & 950.8 & 1093.6 & 947.6 & 768.9 & 837.6 \\
\hline 375.1 & 264.5 & 333.9 & 453.8 & 511.0 & 398.1 & 99.5 & 10.7 \\
\hline 208.8 & 290.1 & 305.7 & 497.0 & 582.5 & 549.6 & 669.4 & 826.8 \\
\hline 222.1 & 392.3 & 362.7 & 441.4 & 334.8 & $\mathbf{5 3 5 . 0}$ & 502.5 & 214.1 \\
\hline 74.0 & 176.3 & 110.0 & 157.1 & -3.6 & 289.6 & 219.1 & 99.6 \\
\hline 49.4 & 27.6 & 50.4 & 6.7 & 113.8 & 9.0 & 7.6 & 15.1 \\
\hline 15.0 & 77.2 & 56.1 & 99.5 & 93.0 & 35.4 & 157.9 & -4.4 \\
\hline 2.0 & 1.4 & 1.8 & 4.0 & 6.1 & 2.2 & 2.8 & 1.9 \\
\hline 8.4 & 15.1 & 20.5 & 13.5 & 30.5 & 30.8 & 22.9 & 20.8 \\
\hline 0.3 & 0.6 & 0.8 & 0.5 & 0.5 & 0.6 & 0.4 & 1.0 \\
\hline 72.9 & 94.1 & 123.0 & 160.1 & 94.6 & 167.4 & 91.9 & 80.0 \\
\hline 22.5 & 19.3 & 6.4 & 5.1 & -15.4 & -10.4 & 3.3 & 15.2 \\
\hline 81.8 & 103.2 & 201.3 & 205.1 & 86.8 & 234.1 & 288.6 & -37.1 \\
\hline 1442.6 & 1494.0 & 2002.0 & 2632.3 & 2415.7 & 2496.2 & 2790.5 & 1997.7 \\
\hline 162.7 & 174.1 & 239.2 & 268.5 & 334.4 & 248.7 & 520.9 & 384.2 \\
\hline 435.4 & 484.2 & 527.8 & 919.6 & 954.9 & 754.5 & 846.4 & 823.6 \\
\hline 144.9 & 126.4 & 260.9 & 314.4 & 297.1 & 300.4 & 113.4 & 89.8 \\
\hline 139.5 & 118.6 & 246.0 & 289.6 & 292.0 & 294.1 & 112.1 & 83.9 \\
\hline
\end{tabular}


6. Financial Business (1)

Billions of dollars

\begin{tabular}{|c|c|c|c|c|c|c|c|c|c|c|}
\hline & & 1995 & 1996 & 1997 & 1998 & 1999 & 2000 & 2001 & 2002 & \\
\hline 55 & Long-term (mortgages) & 5.3 & 7.9 & 14.9 & 24.8 & 5.1 & 6.2 & 1.3 & 5.9 & 55 \\
\hline 56 & Shares and other equity & 381.4 & 484.5 & 535.1 & 770.2 & 618.2 & 846.1 & 851.6 & 326.8 & 56 \\
\hline 57 & Corporate equity issues & -5.6 & -20.8 & -26.6 & 0.9 & -2.4 & 16.8 & 37.3 & 71.0 & 57 \\
\hline 58 & Mutual fund shares & 147.4 & 237.6 & 265.1 & 279.5 & 191.2 & 239.4 & 201.2 & 182.4 & 58 \\
\hline 59 & Money market mutual fund shares & 141.2 & 145.4 & 155.9 & 287.2 & 249.1 & 233.3 & 428.6 & -16.8 & 59 \\
\hline 60 & Equity in government-sponsored enterprises & 2.0 & 1.5 & 1.8 & 4.1 & 6.1 & 2.2 & 2.8 & 2.0 & 60 \\
\hline 61 & Foreign direct investment in U.S. & 4.3 & 14.5 & 4.9 & 34.4 & 42.2 & 140.1 & 80.0 & 16.7 & 61 \\
\hline 62 & Equity in noncorporate business & 14.4 & 9.9 & 13.9 & 9.9 & 10.2 & 39.0 & 11.2 & -4.1 & 62 \\
\hline 63 & Investment by parent & 77.5 & 95.9 & 119.3 & 153.7 & 121.4 & 174.8 & 90.2 & 74.5 & 63 \\
\hline 64 & Stock in Federal Reserve Banks & 0.3 & 0.6 & 0.8 & 0.5 & 0.5 & 0.6 & 0.4 & 1.0 & 64 \\
\hline 65 & Insurance technical reserves & 250.0 & 220.9 & 273.6 & 263.3 & 180.6 & 217.6 & 294.2 & 335.2 & 65 \\
\hline 66 & Other accounts payable & 68.3 & 3.8 & 165.3 & 96.2 & 30.5 & 128.9 & 164.0 & 38.1 & 66 \\
\hline \multicolumn{11}{|c|}{ Memo: } \\
\hline 67 & Net lending or borrowing, financial account (lines 33-50) & 68.7 & 18.3 & -18.0 & -63.7 & 52.2 & -136.7 & -19.1 & -10.1 & 67 \\
\hline \multicolumn{11}{|c|}{ OTHER CHANGES IN VOLUME ACCOUNT: } \\
\hline 68 & Total other volume changes & 49.8 & -7.3 & 21.7 & -4.3 & -48.7 & -156.5 & -104.3 & -205.3 & 68 \\
\hline 69 & Other volume changes & 4.2 & -28.2 & 2.3 & -20.5 & -85.2 & -5.4 & 4.1 & -70.7 & 69 \\
\hline 70 & Less statistical discrepancy (lines 31-[33-50]) * & -45.5 & -20.9 & -19.4 & -16.2 & -36.5 & 151.1 & 108.4 & 134.6 & 70 \\
\hline \multicolumn{11}{|c|}{ REVALUATION ACCOUNT: } \\
\hline 71 & Nonfinancial assets & 90.0 & 84.4 & 81.3 & 91.0 & 182.5 & 187.8 & 137.8 & 203.2 & 71 \\
\hline 72 & Structures & 79.5 & 80.3 & 83.8 & 94.7 & 177.2 & 177.4 & 131.2 & 213.2 & 72 \\
\hline 73 & Equipment and software & 10.5 & 4.1 & -2.5 & -3.7 & 5.3 & 10.4 & 6.6 & -10.0 & 73 \\
\hline 74 & Financial assets & 738.5 & 657.1 & 989.7 & 887.4 & 1421.7 & -615.0 & -1043.9 & -1423.1 & 74 \\
\hline 75 & Corporate equities & 660.0 & 588.7 & 873.4 & 770.7 & 1277.3 & -574.8 & -934.8 & -1258.5 & 75 \\
\hline 76 & Mutual fund shares & 81.1 & 67.0 & 126.9 & 110.1 & 143.3 & -32.2 & -105.3 & -171.1 & 76 \\
\hline 77 & U.S. direct investment abroad & -2.6 & 1.4 & -8.9 & 6.6 & 1.2 & -8.1 & -3.8 & 6.5 & 77 \\
\hline 78 & Liabilities & 1095.9 & 981.3 & 1655.5 & 999.8 & 1209.2 & 82.3 & -1228.1 & -1684.0 & 78 \\
\hline 79 & Corporate equity issues & 395.6 & 371.2 & 711.6 & 174.3 & -128.6 & 715.1 & -230.8 & -354.0 & 79 \\
\hline 80 & Mutual fund shares & 228.0 & 252.0 & 381.9 & 344.2 & 734.1 & -342.5 & -501.0 & -679.6 & 80 \\
\hline 81 & Foreign direct investment in U.S. & 10.9 & -7.4 & 21.6 & 0.6 & -19.7 & -21.1 & -15.3 & 8.4 & 81 \\
\hline 82 & Equity in noncorporate business & -15.9 & -8.5 & -9.3 & -12.1 & -19.0 & -56.1 & -21.0 & -17.2 & 82 \\
\hline 83 & Pension fund reserves & 477.2 & 374.0 & 549.8 & 492.8 & 642.4 & -213.1 & -460.0 & -641.7 & 83 \\
\hline 84 & Changes in net worth due to nominal holding gains/losses & -267.3 & -239.9 & -584.6 & -21.4 & 395.1 & -509.6 & 322.0 & 464.1 & 84 \\
\hline \multicolumn{11}{|c|}{ CHANGES IN BALANCE SHEET ACCOUNT: } \\
\hline 85 & Change in net worth (lines $28+31+68+84$ ) $* *$ & -180.2 & -216.9 & -523.8 & -15.2 & 390.9 & -646.4 & 294.7 & 372.0 & 85 \\
\hline \multicolumn{11}{|c|}{ BALANCE SHEET ACCOUNT (end of period): } \\
\hline 86 & Total assets & 23097.8 & 25366.6 & 28490.4 & 32128.5 & 36225.4 & 38162.8 & 40012.1 & 40706.1 & 86 \\
\hline 87 & Nonfinancial assets & 1883.5 & 1983.3 & 2111.0 & 2262.6 & 2450.4 & 2624.0 & 2730.9 & 2836.5 & 87 \\
\hline 88 & Structures & 1402.9 & 1467.7 & 1562.9 & 1663.5 & 1781.1 & 1899.2 & 1985.4 & 2081.0 & 88 \\
\hline 89 & Equipment and software & 480.5 & 515.5 & 548.2 & 599.1 & 669.4 & 724.8 & 745.6 & 755.6 & 89 \\
\hline 90 & Financial assets & 21214.3 & 23383.4 & 26379.4 & 29865.9 & 33775.0 & 35538.9 & 37281.1 & 37869.6 & 90 \\
\hline 91 & Monetary gold and SDRs & 21.2 & 20.8 & 20.2 & 20.2 & 17.2 & 13.2 & 13.2 & 13.2 & 91 \\
\hline 92 & Currency and deposits & 498.9 & 544.5 & 600.8 & 692.2 & 734.0 & 757.6 & 960.8 & 985.7 & 92 \\
\hline 93 & Securities other than shares & 7279.8 & 7653.2 & 8354.2 & 9230.9 & 10160.6 & 10792.8 & 11794.4 & 12727.9 & 93 \\
\hline 94 & Open market paper & 525.7 & 578.1 & 714.4 & 835.6 & 1058.7 & 1225.6 & 1129.5 & 1014.4 & 94 \\
\hline 95 & Treasury securities & 1606.8 & 1514.5 & 1557.7 & 1492.7 & 1432.8 & 1424.8 & 1447.9 & 1593.0 & 95 \\
\hline 96 & Agency- and GSE-backed securities & 1967.3 & 2099.7 & 2254.5 & 2610.3 & 3012.1 & 3243.2 & 3800.6 & 4391.4 & 96 \\
\hline 97 & Municipal securities & 684.5 & 719.0 & 773.1 & 855.7 & 878.0 & 885.1 & 961.5 & 1010.8 & 97 \\
\hline 98 & Corporate and foreign bonds & 1989.2 & 2180.6 & 2452.9 & 2793.7 & 3094.9 & 3309.2 & 3689.2 & 3928.0 & 98 \\
\hline 99 & Nonmarketable government securities & 506.3 & 561.4 & 601.7 & 642.9 & 684.0 & 704.9 & 765.8 & 790.3 & 99 \\
\hline 100 & Loans & 7301.7 & 7856.3 & 8495.9 & 9446.7 & 10542.0 & 11500.7 & 12269.3 & 13106.9 & 100 \\
\hline 101 & Short-term & 3104.9 & 3369.4 & 3703.3 & 4157.1 & 4668.4 & 5077.6 & 5176.8 & 5187.5 & 101 \\
\hline 102 & Long-term (mortgages) & 4196.8 & 4486.9 & 4792.6 & 5289.6 & 5873.6 & 6423.1 & 7092.5 & 7919.4 & 102 \\
\hline 103 & Shares and other equity & 4505.2 & 5554.6 & 6906.9 & 8235.7 & 9992.3 & 9912.2 & 9370.8 & 8161.8 & 103 \\
\hline 104 & Corporate equities & 3258.8 & 4023.8 & 5007.2 & 5935.0 & 7208.8 & 6923.6 & 6207.9 & 5049.1 & 104 \\
\hline 105 & Mutual fund shares & 365.5 & 460.0 & 637.4 & 754.2 & 1011.2 & 988.0 & 890.3 & 734.3 & 105 \\
\hline 106 & Money market mutual fund shares & 180.5 & 257.7 & 312.2 & 411.6 & 504.6 & 540.0 & 697.9 & 693.5 & 106 \\
\hline
\end{tabular}




\section{Financial Business (1)}

Billions of dollars

\begin{tabular}{|c|c|c|c|c|c|c|c|c|c|c|}
\hline & & 1995 & 1996 & 1997 & 1998 & 1999 & 2000 & 2001 & 2002 & \\
\hline 107 & Equity in government-sponsored enterprises & 15.1 & 16.5 & 18.3 & 22.3 & 28.4 & 30.5 & 33.3 & 35.2 & 107 \\
\hline 108 & U.S. direct investment abroad & 106.8 & 123.3 & 134.9 & 155.0 & 186.6 & 209.4 & 228.5 & 255.8 & 108 \\
\hline 109 & Stock in Federal Reserve Banks & 4.0 & 4.6 & 5.4 & 6.0 & 6.4 & 7.0 & 7.4 & 8.4 & 109 \\
\hline 110 & Investment in subsidiaries & 574.4 & 668.5 & 791.5 & 951.7 & 1046.3 & 1213.7 & 1305.6 & 1385.6 & 110 \\
\hline 111 & Insurance technical reserves & 432.1 & 465.8 & 494.1 & 516.7 & 523.1 & 509.4 & 501.1 & 497.6 & 111 \\
\hline 112 & Other accounts receivable & 1175.4 & 1288.2 & 1507.2 & 1723.4 & 1805.8 & 2052.9 & 2371.4 & 2376.5 & 112 \\
\hline 113 & Total liabilities and net worth & 23097.8 & 25366.6 & 28490.4 & 32128.5 & 36225.4 & 38162.8 & 40012.1 & 40706.1 & 113 \\
\hline 114 & Liabilities & 21864.6 & 24350.3 & 27997.9 & 31651.1 & 35357.2 & 37941.0 & 39495.5 & 39817.6 & 114 \\
\hline 115 & Currency and deposits & 4295.6 & 4471.5 & 4709.0 & 4979.4 & 5311.7 & 5564.2 & 6069.0 & 6450.3 & 115 \\
\hline 116 & Securities other than shares & 4122.2 & 4606.4 & 5125.1 & 6044.7 & 6999.6 & 7758.1 & 8601.9 & 9425.5 & 116 \\
\hline 117 & Agency- and GSE-backed securities & 2376.8 & 2608.2 & 2821.1 & 3292.0 & 3884.0 & 4317.4 & 4944.1 & 5498.1 & 117 \\
\hline 118 & Corporate bonds & 1258.5 & 1419.1 & 1558.3 & 1846.0 & 2032.7 & 2226.0 & 2488.4 & 2821.5 & 118 \\
\hline 119 & Commercial paper & 486.9 & 579.1 & 745.7 & 906.7 & 1082.9 & 1214.7 & 1169.4 & 1105.9 & 119 \\
\hline 120 & Loans & 1097.7 & 1224.1 & 1485.0 & 1799.4 & 2096.5 & 2396.8 & 2522.9 & 2612.7 & 120 \\
\hline 121 & Short-term & 1073.6 & 1192.2 & 1438.2 & 1727.8 & 2019.8 & 2313.9 & 2438.7 & 2522.6 & 121 \\
\hline 122 & Long-term (mortgages) & 24.1 & 31.9 & 46.8 & 71.6 & 76.7 & 82.9 & 84.2 & 90.1 & 122 \\
\hline 123 & Shares and other equity & 4537.7 & 5629.5 & 7270.3 & 8547.6 & 9732.5 & 10874.0 & 10957.6 & 10242.0 & 123 \\
\hline 124 & Corporate equity issues & 1284.0 & 1634.3 & 2319.3 & 2494.5 & 2363.4 & 3095.3 & 2901.8 & 2618.8 & 124 \\
\hline 125 & Mutual fund shares & 1852.8 & 2342.4 & 2989.4 & 3613.1 & 4538.5 & 4435.3 & 4135.5 & 3638.4 & 125 \\
\hline 126 & Money market mutual fund shares & 741.3 & 886.7 & 1042.5 & 1329.7 & 1578.8 & 1812.1 & 2240.7 & 2223.9 & 126 \\
\hline 127 & Equity in government-sponsored enterprises & 18.3 & 19.7 & 21.5 & 25.5 & 31.6 & 33.8 & 36.5 & 38.5 & 127 \\
\hline 128 & Foreign direct investment in U.S. & 36.1 & 43.2 & 69.7 & 104.7 & 127.2 & 246.2 & 310.9 & 336.1 & 128 \\
\hline 129 & Equity in noncorporate business & 1.4 & 2.8 & 7.4 & 5.2 & -3.6 & -20.7 & -30.5 & -51.7 & 129 \\
\hline 130 & Investment by parent & 599.9 & 695.8 & 815.1 & 968.8 & 1090.2 & 1265.0 & 1355.2 & 1429.8 & 130 \\
\hline 131 & Stock in Federal Reserve Banks & 4.0 & 4.6 & 5.4 & 6.0 & 6.4 & 7.0 & 7.4 & 8.4 & 131 \\
\hline 132 & Insurance technical reserves & 6851.7 & 7461.1 & 8301.5 & 9080.4 & 9940.2 & 9926.6 & 9733.0 & 9388.6 & 132 \\
\hline 133 & Other accounts payable & 959.7 & 957.7 & 1107.0 & 1199.7 & 1276.6 & 1421.2 & 1611.2 & 1698.4 & 133 \\
\hline 134 & Net worth & 1233.2 & 1016.3 & 492.5 & 477.4 & 868.2 & 221.8 & 516.6 & 888.5 & 134 \\
\hline
\end{tabular}

(1) Includes other financial institutions, depository institutions, insurance companies and pension funds, and monetary authority.

* The discrepancy is the difference between net lending or borrowing derived in the capital account and the same concept derived in the financial account. The discrepancy reflects differences in source data, timing of recorded flows, and other statistical differences between the capital and financial accounts.

** Partial--Does not include revaluation of tangible assets. 


\section{CURRENT ACCOUNT:}

1 Gross domestic product(GDP)/Gross value added

2 Less consumption of fixed capital

Equals net domestic product/Net value added

Compensation of employees (paid)

Wages and salaries

Employers' social contributions

Operating surplus, net

8 Net national income/Balance of primary incomes, net

Operating surplus, net

Taxes on production and imports, receivable

Subsidies (paid)

Property income (received)

Interest

Less uses of property income (interest paid)

6 Net national income/Balance of primary incomes, net

17 Plus current taxes on income, wealth, etc. (received)

8 Plus social benefits (received)

Less social contributions (paid)

Plus other current transfers (received)

Less other current transfers (paid)

22 Equals disposable income, net

23 Less final consumption expenditures

24 Equals net saving

\section{CAPITAL ACCOUNT:}

25 Net saving and capital transfers

6 Net saving

27 Capital transfers received (net)

8 Capital formation, net

Gross fixed capital formation (acq. of produced nonfinancial assets)

Less consumption of fixed capita

Acq. of nonproduced nonfinancial assets

32 Net lending or borrowing, capital account (lines 25-28)

FINANCIAL ACCOUNT:

\begin{tabular}{ll}
$\mathbf{3 3}$ & Net lending or borrowing (line 32) \\
$\mathbf{3 4}$ & Net acquisition of financial assets \\
$\mathbf{3 5}$ & Monetary gold and SDRs \\
$\mathbf{3 6}$ & Currency and deposits \\
37 & Official foreign exchange \\
38 & Net IMF position \\
39 & Currency and transferable deposits \\
40 & Time and savings deposits \\
41 & Nonofficial foreign currencies \\
& \\
$\mathbf{4 2}$ & Loans \\
43 & Short-term \\
44 & Consumer credit \\
45 & Other loans and advances \\
46 & Long-term (mortgages) \\
& \\
$\mathbf{4 7}$ & Shares and other equity \\
48 & Equity in international organizations \\
49 & Equity in government-sponsored enterprises \\
& Other accounts receivable \\
$\mathbf{5 0}$ & Trade receivables \\
51 & Taxes receivable \\
52 & Other (miscellaneous assets) \\
53 & \\
$\mathbf{5 4}$ & Net incurrence of liabilities \\
$\mathbf{5 5}$ & Monetary gold and SDRs (SDR certificates) \\
$\mathbf{5 6}$ & Currency and deposits (treasury currency) \\
& \\
\hline
\end{tabular}

\begin{tabular}{|c|c|c|c|c|c|c|c|}
\hline 338.7 & 343.7 & 349.3 & 352.9 & 361.9 & 378.7 & 386.9 & 408.9 \\
\hline 81.9 & 82.0 & 82.5 & 82.8 & 84.8 & 87.2 & 88.2 & 89.1 \\
\hline 256.9 & 261.6 & 266.8 & 270.1 & 277.0 & 291.6 & 298.7 & 319.8 \\
\hline 257.5 & 262.9 & 266.5 & 270.0 & 277.4 & 293.9 & 302.8 & 323.0 \\
\hline 174.7 & 175.7 & 177.3 & 179.7 & 184.3 & 195.8 & 200.5 & 213.3 \\
\hline 82.8 & 87.2 & 89.2 & 90.3 & 93.1 & 98.1 & 102.3 & 109.7 \\
\hline-0.6 & -1.2 & 0.3 & 0.1 & -0.3 & -2.3 & -4.1 & -3.1 \\
\hline-225.1 & -232.3 & -228.0 & -231.1 & -221.4 & -216.3 & -199.0 & -161.5 \\
\hline-0.6 & -1.2 & 0.3 & 0.1 & -0.3 & -2.3 & -4.1 & -3.1 \\
\hline 75.9 & 73.2 & 78.2 & 81.1 & 83.9 & 87.8 & 86.0 & 87.6 \\
\hline-33.7 & -34.0 & -32.4 & -35.0 & -43.8 & -43.8 & -47.6 & -37.2 \\
\hline 23.7 & 26.9 & 25.9 & 21.5 & 21.5 & 25.2 & 24.4 & 20.6 \\
\hline 21.2 & 23.0 & 21.4 & 17.7 & 18.0 & 20.1 & 17.9 & 15.9 \\
\hline 2.5 & 4.0 & 4.5 & 3.8 & 3.5 & 5.1 & 6.5 & 4.7 \\
\hline 290.4 & 297.3 & 300.0 & 298.8 & 282.7 & 283.3 & 257.5 & 229.3 \\
\hline-225.1 & -232.3 & -228.0 & -231.1 & -221.4 & -216.3 & -199.0 & -161.5 \\
\hline 769.2 & 859.2 & 952.4 & 1035.8 & 1111.9 & 1225.8 & 1168.9 & 993.1 \\
\hline 519.2 & 542.8 & 576.4 & 613.8 & 651.6 & 691.7 & 715.4 & 736.7 \\
\hline 642.7 & 680.0 & 706.3 & 719.2 & 738.0 & 772.5 & 840.2 & 920.0 \\
\hline 19.1 & 23.1 & 19.9 & 21.5 & 22.7 & 25.7 & 27.4 & 25.8 \\
\hline 196.3 & 208.2 & 212.5 & 227.4 & 248.0 & 265.6 & 290.3 & 323.4 \\
\hline 243.5 & 304.5 & 401.9 & 493.4 & 578.7 & 688.8 & 582.2 & 350.8 \\
\hline 440.5 & 446.3 & 457.7 & 454.6 & 475.1 & 499.3 & 531.7 & 590.8 \\
\hline 97.0 & -141.8 & -55.8 & 38.8 & 103.6 & 189.5 & 50.5 & -240.0 \\
\hline
\end{tabular}

$\begin{array}{rrrrrrrrr}\mathbf{- 2 0 9 . 8} & \mathbf{- 1 5 2 . 5} & \mathbf{- 6 4 . 2} & \mathbf{3 5 . 3} & \mathbf{9 6 . 3} & \mathbf{1 8 1 . 4} & \mathbf{3 7 . 7} & \mathbf{- 2 5 8 . 8} & \mathbf{2 5} \\ -197.0 & -141.8 & -55.8 & 38.8 & 103.6 & 189.5 & 50.5 & -240.0 & 26 \\ -12.8 & -10.7 & -8.5 & -3.6 & -7.4 & -8.1 & -12.9 & -18.7 & 27 \\ & & & & & & & & \\ \mathbf{- 1 0 . 5} & \mathbf{- 4 . 7} & \mathbf{- 1 7 . 0} & \mathbf{- 1 2 . 6} & \mathbf{- 5 . 0} & \mathbf{- 8 . 0} & -\mathbf{7 . 8} & \mathbf{- 0 . 2} & \mathbf{2 8} \\ 78.7 & 81.1 & 73.2 & 75.8 & 80.8 & 79.5 & 81.2 & 88.7 & 29 \\ 81.9 & 82.0 & 82.5 & 82.8 & 84.8 & 87.2 & 88.2 & 89.1 & 30 \\ -7.4 & -3.8 & -7.6 & -5.7 & -1.0 & -0.3 & -0.7 & 0.2 & 31 \\ & & & & & & & & \\ \mathbf{- 1 9 9 . 3} & \mathbf{- 1 4 7 . 8} & \mathbf{- 4 7 . 3} & \mathbf{4 7 . 9} & \mathbf{1 0 1 . 3} & \mathbf{1 8 9 . 3} & \mathbf{4 5 . 4} & \mathbf{- 2 5 8 . 7} & \mathbf{3 2}\end{array}$

\begin{tabular}{|c|c|c|c|c|c|c|c|}
\hline-199.3 & -147.8 & -47.3 & 47.9 & 101.3 & 189.3 & 45.4 & -258.7 \\
\hline-11.5 & 2.5 & -12.6 & -8.6 & 71.4 & -70.7 & 51.2 & 16.6 \\
\hline 0.8 & -0.4 & 0.4 & 0.1 & -0.0 & 0.7 & 0.6 & 0.8 \\
\hline 6.1 & 9.8 & 2.5 & -9.6 & 60.4 & -65.5 & 49.2 & 6.4 \\
\hline 3.2 & -3.8 & -1.5 & 0.8 & -1.6 & 0.9 & 0.3 & 1.9 \\
\hline 2.5 & 1.3 & 3.6 & 5.1 & -5.5 & -2.3 & 3.6 & 6.1 \\
\hline-0.0 & 11.0 & -0.5 & -16.7 & 66.2 & -65.1 & 41.1 & -18.7 \\
\hline 0.3 & 1.4 & 1.0 & 1.3 & 0.7 & 1.0 & 4.2 & 17.1 \\
\hline 0.3 & -0.1 & -0.0 & -0.1 & 0.6 & 0.0 & -0.1 & 0.1 \\
\hline-7.0 & -1.3 & 3.1 & 11.6 & 6.4 & 11.6 & 6.0 & 9.8 \\
\hline 6.6 & 5.9 & 7.6 & 12.5 & 6.4 & 12.5 & 7.1 & 9.2 \\
\hline 3.2 & 7.7 & 10.8 & 9.0 & 13.6 & 16.1 & 13.1 & 12.7 \\
\hline 3.4 & -1.8 & -3.1 & 3.4 & -7.1 & -3.6 & -5.9 & -3.4 \\
\hline-13.5 & -7.2 & -4.5 & -0.8 & -0.1 & -0.9 & -1.1 & 0.5 \\
\hline 1.5 & 1.8 & 1.6 & 1.6 & 1.5 & 1.5 & 1.7 & 1.7 \\
\hline 1.5 & 1.8 & 1.6 & 1.6 & 1.5 & 1.5 & 1.7 & 1.7 \\
\hline 0 & 0 & 0 & 0 & 0 & 0 & 0 & 0 \\
\hline-13.0 & -7.4 & -20.1 & -12.4 & 3.2 & -19.1 & -6.3 & -2.0 \\
\hline-1.6 & 0.9 & -3.2 & 1.5 & 4.6 & 5.3 & 7.3 & -3.3 \\
\hline-7.5 & 0.0 & -10.0 & -8.9 & 1.6 & -21.5 & -13.4 & 2.8 \\
\hline-3.8 & -8.4 & -7.0 & -5.0 & -3.0 & -2.9 & -0.3 & -1.5 \\
\hline 169.0 & 198.1 & 56.5 & -24.6 & -34.0 & -268.7 & 53.5 & 285.9 \\
\hline 2.2 & -0.5 & -0.5 & 0 & -3.0 & -4.0 & 0 & 0 \\
\hline 0.7 & 0.5 & 0.5 & 0.6 & 1.0 & 2.4 & 1.3 & 1.0 \\
\hline
\end{tabular}


7. Federal Government

Billions of dollars

\begin{tabular}{|c|c|c|c|c|c|c|c|c|c|c|}
\hline & & 1995 & 1996 & 1997 & 1998 & 1999 & 2000 & 2001 & 2002 & \\
\hline 57 & Securities other than shares & 144.4 & 144.9 & 23.1 & -52.6 & -71.2 & -295.9 & -5.6 & 257.5 & 57 \\
\hline 58 & Treasury securities including savings bonds & 142.9 & 146.6 & 23.2 & -54.6 & -71.0 & -294.9 & -5.0 & 257.0 & 58 \\
\hline 59 & Federal agency securities & 1.5 & -1.6 & -0.1 & 2.0 & -0.2 & -1.0 & -0.5 & 0.5 & 59 \\
\hline 60 & Insurance technical reserves & 21.8 & 55.7 & 42.0 & 42.5 & 42.5 & 22.3 & 62.2 & 26.1 & 60 \\
\hline 61 & Insurance reserves & 1.0 & 0.6 & 1.7 & 1.3 & 1.4 & 1.4 & 1.4 & 1.6 & 61 \\
\hline 62 & Nonmarketable securities held by pension plans & 20.8 & 55.1 & 40.3 & 41.2 & 41.1 & 20.9 & 60.8 & 24.5 & 62 \\
\hline 63 & Other accounts payable & -0.1 & -2.6 & -8.6 & -15.1 & -3.4 & 6.4 & -4.5 & 1.3 & 63 \\
\hline 64 & Trade payables & -4.6 & 0.7 & -8.8 & -8.0 & -0.4 & 4.4 & 3.4 & 1.8 & 64 \\
\hline 65 & Other (miscellaneous liabilities) & 4.5 & -3.3 & 0.3 & -7.1 & -2.9 & 2.0 & -7.8 & -0.4 & 65 \\
\hline \multicolumn{11}{|c|}{ Memo: } \\
\hline 66 & Net lending or borrowing, financial account (lines 34-54) & -180.4 & -195.6 & -69.1 & 16.0 & 105.4 & 198.0 & -2.3 & -269.3 & 66 \\
\hline \multicolumn{11}{|c|}{ OTHER CHANGES IN VOLUME ACCOUNT: } \\
\hline 67 & Total other volume changes & 29.8 & -48.2 & -11.6 & -28.7 & 46.0 & 36.2 & -4.5 & -29.2 & 67 \\
\hline 68 & Other volume changes & 11.0 & -0.4 & 10.3 & 3.2 & 41.9 & 27.5 & 43.2 & -18.5 & 68 \\
\hline 69 & Less statistical discrepancy (lines 32-[34-54]) * & -18.8 & 47.9 & 21.8 & 31.9 & -4.1 & -8.7 & 47.7 & 10.6 & 69 \\
\hline \multicolumn{11}{|c|}{ REVALUATION ACCOUNT: } \\
\hline 70 & Nonfinancial assets & 45.7 & 33.6 & 40.7 & 27.0 & 44.1 & 41.6 & 33.4 & 30.8 & 70 \\
\hline 71 & Structures & 38.0 & 33.7 & 40.9 & 30.3 & 38.4 & 43.0 & 32.6 & 30.0 & 71 \\
\hline 72 & Equipment and software & 7.6 & -0.2 & -0.2 & -3.3 & 5.7 & -1.4 & 0.8 & 0.8 & 72 \\
\hline 73 & Financial assets & 0.3 & -0.8 & -1.6 & 1.3 & -0.9 & -1.3 & -1.0 & -1.4 & 73 \\
\hline 74 & Currency and checkable deposits & -5.6 & 5.2 & 3.8 & -1.7 & -1.4 & 1.4 & 1.5 & -0.6 & 74 \\
\hline 75 & Monetary gold, SDRs, and official foreign exchange & 6.0 & -6.0 & -5.4 & 3.1 & 0.5 & -2.7 & -2.5 & -0.8 & 75 \\
\hline 76 & Changes in net worth due to nominal holding gains/losses & 46.0 & 32.7 & 39.1 & 28.3 & 43.2 & 40.3 & 32.4 & 29.4 & 76 \\
\hline \multicolumn{11}{|c|}{ CHANGES IN BALANCE SHEET ACCOUNT: } \\
\hline 77 & Change in net worth (lines $28+32+67+76$ ) $* *$ & -133.9 & -168.0 & -36.6 & 34.9 & 185.5 & 257.8 & 65.6 & -258.6 & 77 \\
\hline \multicolumn{11}{|c|}{ BALANCE SHEET ACCOUNT (end of period): } \\
\hline 78 & Total assets & 1756.3 & 1790.3 & 1809.3 & 1826.8 & 1981.0 & 1967.9 & 2094.6 & 2122.2 & 78 \\
\hline 79 & Nonfinancial assets & 1314.4 & 1343.2 & 1367.0 & 1381.4 & 1420.5 & 1454.1 & 1479.8 & 1510.4 & 79 \\
\hline 80 & Structures & 787.7 & 819.0 & 848.5 & 869.4 & 901.9 & 936.5 & 959.2 & 987.0 & 80 \\
\hline 81 & Equipment and software & 526.7 & 524.3 & 518.4 & 511.9 & 518.6 & 517.6 & 520.6 & 523.4 & 81 \\
\hline 82 & Financial assets & 441.9 & 447.1 & 442.3 & 445.4 & 560.5 & 513.8 & 614.9 & 611.8 & 82 \\
\hline 83 & Monetary gold and SDRs & 11.0 & 10.3 & 10.0 & 10.6 & 10.3 & 10.5 & 10.8 & 12.2 & 83 \\
\hline 84 & Currency and deposits & 68.1 & 77.4 & 79.0 & 70.3 & 130.0 & 63.7 & 112.3 & 116.8 & 84 \\
\hline 85 & Official foreign exchange & 28.0 & 19.0 & 13.8 & 16.2 & 16.0 & 15.6 & 14.4 & 16.9 & 85 \\
\hline 86 & Net IMF position & 14.7 & 15.5 & 18.2 & 24.2 & 18.0 & 14.9 & 17.9 & 22.1 & 86 \\
\hline 87 & Currency and transferable deposits & 22.2 & 38.3 & 41.6 & 23.2 & 87.9 & 24.3 & 66.9 & 47.5 & 87 \\
\hline 88 & Time and savings deposits & 0.9 & 2.4 & 3.4 & 4.7 & 5.4 & 6.3 & 10.5 & 27.6 & 88 \\
\hline 89 & Nonofficial foreign currencies & 2.3 & 2.2 & 2.1 & 2.0 & 2.6 & 2.6 & 2.6 & 2.7 & 89 \\
\hline 90 & Loans & 207.8 & 206.5 & 209.8 & 221.6 & 261.1 & 272.7 & 278.7 & 288.5 & 90 \\
\hline 91 & Short-term & 150.3 & 156.3 & 164.1 & 176.7 & 183.3 & 195.8 & 203.0 & 212.2 & 91 \\
\hline 92 & Consumer credit & 9.9 & 17.6 & 28.3 & 37.4 & 50.9 & 67.0 & 80.1 & 92.8 & 92 \\
\hline 93 & Other loans and advances & 140.5 & 138.7 & 135.7 & 139.3 & 132.4 & 128.8 & 122.9 & 119.4 & 93 \\
\hline 94 & Long-term (mortgages) & 57.5 & 50.3 & 45.7 & 44.9 & 77.7 & 76.9 & 75.8 & 76.3 & 94 \\
\hline 95 & Shares and other equity & 27.4 & 29.2 & 30.8 & 32.4 & 33.9 & 35.4 & 37.1 & 38.7 & 95 \\
\hline 96 & Equity in international organizations & 27.4 & 29.2 & 30.8 & 32.4 & 33.9 & 35.4 & 37.1 & 38.7 & 96 \\
\hline 97 & Equity in government-sponsored enterprises & 0 & 0 & 0 & 0 & 0 & 0 & 0 & 0 & 97 \\
\hline 98 & Other accounts receivable & 127.5 & 123.6 & 112.6 & 110.5 & 125.3 & 131.5 & 176.0 & 155.7 & 98 \\
\hline 99 & Trade receivables & 23.1 & 24.0 & 20.8 & 22.3 & 22.9 & 28.1 & 35.5 & 32.2 & 99 \\
\hline 100 & Taxes receivable & 17.3 & 20.7 & 20.0 & 21.4 & 38.5 & 42.4 & 79.8 & 64.3 & 100 \\
\hline 101 & Other (miscellaneous assets) & 87.2 & 78.8 & 71.9 & 66.9 & 63.9 & 61.0 & 60.7 & 59.2 & 101 \\
\hline 102 & Total liabilities and net worth & 1756.3 & 1790.3 & 1809.3 & 1826.8 & 1981.0 & 1967.9 & 2094.6 & 2122.2 & 102 \\
\hline 103 & Liabilities & 4289.2 & 4491.2 & 4546.8 & 4529.4 & 4498.1 & 4227.2 & 4288.3 & 4574.5 & 103 \\
\hline 104 & Monetary gold and SDRs (SDR certificates) & 10.2 & 9.7 & 9.2 & 9.2 & 6.2 & 2.2 & 2.2 & 2.2 & 104 \\
\hline 105 & Currency and deposits (treasury currency) & 18.3 & 18.9 & 19.3 & 19.9 & 20.9 & 23.2 & 24.5 & 25.5 & 105 \\
\hline
\end{tabular}




\section{Federal Government}

Billions of dollars

\begin{tabular}{|c|c|c|c|c|c|c|c|c|c|c|}
\hline & & 1995 & 1996 & 1997 & 1998 & 1999 & 2000 & 2001 & 2002 & \\
\hline 106 & Securities other than shares & 3636.7 & 3781.7 & 3804.8 & 3752.2 & 3681.0 & 3385.1 & 3379.5 & 3637.0 & 106 \\
\hline 107 & Treasury securities including savings bonds & 3608.5 & 3755.1 & 3778.3 & 3723.7 & 3652.7 & 3357.8 & 3352.7 & 3609.8 & 107 \\
\hline 108 & Federal agency securities & 28.2 & 26.6 & 26.5 & 28.5 & 28.3 & 27.3 & 26.8 & 27.3 & 108 \\
\hline 109 & Insurance technical reserves & 536.2 & 591.9 & 634.0 & 676.5 & 719.0 & 741.3 & 803.6 & 829.7 & 109 \\
\hline 110 & Insurance reserves & 29.9 & 30.5 & 32.3 & 33.6 & 35.0 & 36.4 & 37.8 & 39.4 & 110 \\
\hline 111 & Nonmarketable securities held by pension plans & 506.3 & 561.4 & 601.7 & 642.9 & 684.0 & 704.9 & 765.8 & 790.3 & 111 \\
\hline 112 & Other accounts payable & 87.7 & 89.0 & 79.6 & 71.7 & 71.1 & 75.4 & 78.6 & 80.1 & 112 \\
\hline 113 & Trade payables & 81.1 & 81.8 & 72.9 & 65.0 & 64.5 & 69.0 & 72.3 & 74.1 & 113 \\
\hline 114 & Other (miscellaneous liabilities) & 6.7 & 7.3 & 6.6 & 6.7 & 6.6 & 6.4 & 6.2 & 6.0 & 114 \\
\hline 115 & Net worth & -2532.9 & -2700.9 & -2737.6 & -2702.6 & -2517.2 & -2259.3 & -2193.7 & -2452.3 & 115 \\
\hline
\end{tabular}

* The discrepancy is the difference between net lending or borrowing derived in the capital account and the same concept derived in the financial account. The discrepancy reflects

differences in source data, timing of recorded flows, and other statistical differences between the capital and financial accounts.

** Partial--Does not include revaluation of tangible assets. 


\section{CURRENT ACCOUNT:}

1 Gross domestic product(GDP)/Gross value added

2 Less consumption of fixed capital

3 Equals net domestic product/Net value added

Compensation of employees (paid)

Wages and salaries

Employers' social contributions

Operating surplus, net

8 Net national income/Balance of primary incomes, net

Operating surplus, net

Taxes on production and imports, receivable

Subsidies (paid)

Property income (received)

Interest

Distributed income of corporations (dividends)

Rents

Less uses of property income (interest paid)

17 Net national income/Balance of primary incomes, net

18 Plus current taxes on income, wealth, etc. (received)

19 Plus social benefits (received)

Less social contributions (paid)

21 Plus other current transfers (received)

22 Equals disposable income, net

23 Less final consumption expenditures

24 Equals net saving

\section{CAPITAL ACCOUNT:}

25 Net saving and capital transfers

26 Net saving

27 Capital transfers received (net)

28 Capital formation, net

29 Gross fixed capital formation (acq. of produced nonfinancial assets)

Less consumption of fixed capital

1 Acq. of nonproduced nonfinancial assets

32 Net lending or borrowing, capital account (lines 25-28)

\section{FINANCIAL ACCOUNT:}

$\begin{array}{ll}\mathbf{3 3} & \text { Net lending or borrowing (line 32) } \\ \mathbf{3 4} & \text { Net acquisition of financial assets } \\ \mathbf{3 5} & \text { Currency and deposits } \\ 36 & \text { Currency and transferable deposits } \\ 37 & \text { Time and savings deposits } \\ & \\ \mathbf{3 8} & \text { Securities other than shares } \\ 39 & \text { Open market paper } \\ 40 & \text { Treasury securities } \\ 41 & \text { Agency- and GSE-backed securities } \\ 42 & \text { Municipal securities } \\ 43 & \text { Corporate and foreign bonds } \\ & \\ \mathbf{4 4} & \text { Loans } \\ 45 & \text { Short-term (security RPs) } \\ 46 & \text { Long-term (mortgages) } \\ & \\ \mathbf{4 7} & \text { Shares and other equity } \\ 48 & \text { Corporate equities } \\ 49 & \text { Mutual fund shares } \\ & \text { Other accounts receivable } \\ \mathbf{5 0} & \text { Taxes receivable } \\ 51 & \text { Other (miscellaneous assets) } \\ 52 & \\ \mathbf{5 3} & \text { Net incurrence of liabilities } \\ & \\ \mathbf{5 4} & \text { Securities other than shares (municipals) } \\ 55 & \text { Short-term } \\ 56 & \text { Other } \\ \mathbf{5 7} & \text { Loans (short-term) } \\ & \end{array}$

$\begin{array}{rrrrrrrrr}\mathbf{6 6 6 . 7} & \mathbf{6 9 3 . 0} & \mathbf{7 2 0 . 4} & \mathbf{7 5 2 . 6} & \mathbf{7 9 0 . 5} & \mathbf{8 3 4 . 4} & \mathbf{8 8 3 . 8} & \mathbf{9 3 0 . 9} & \mathbf{1} \\ & & & & & & & & \\ \mathbf{8 3 . 1} & \mathbf{8 7 . 2} & \mathbf{9 1 . 6} & \mathbf{9 6 . 2} & \mathbf{1 0 2 . 1} & \mathbf{1 0 9 . 8} & \mathbf{1 1 7 . 7} & \mathbf{1 2 1 . 7} & \mathbf{2} \\ & & & & & & & & \\ \mathbf{5 8 3 . 6} & \mathbf{6 0 5 . 8} & \mathbf{6 2 8 . 8} & \mathbf{6 5 6 . 4} & \mathbf{6 8 8 . 4} & \mathbf{7 2 4 . 6} & \mathbf{7 6 6 . 1} & \mathbf{8 0 9 . 1} & \mathbf{3} \\ 571.5 & 591.9 & 616.5 & 646.2 & 677.9 & 716.9 & 760.8 & 803.2 & 4 \\ 450.8 & 468.7 & 490.8 & 517.5 & 545.0 & 578.9 & 615.2 & 646.6 & 5 \\ 120.7 & 123.2 & 125.7 & 128.7 & 132.9 & 138.1 & 145.6 & 156.6 & 6 \\ 12.0 & 13.9 & 12.3 & 10.2 & 10.4 & 7.7 & 5.4 & 5.9 & 7 \\ & & & & & & & & \\ \mathbf{4 9 8 . 3} & \mathbf{5 2 6 . 6} & \mathbf{5 5 2 . 0} & \mathbf{5 7 5 . 9} & \mathbf{6 1 0 . 9} & \mathbf{6 4 0 . 8} & \mathbf{6 5 0 . 6} & \mathbf{6 8 2 . 9} & \mathbf{8} \\ 12.0 & 13.9 & 12.3 & 10.2 & 10.4 & 7.7 & 5.4 & 5.9 & 9 \\ 482.4 & 507.9 & 533.8 & 558.8 & 590.2 & 621.1 & 643.8 & 672.5 & 10 \\ -0.3 & -0.3 & -0.4 & -0.4 & -0.4 & -0.5 & -7.7 & -1.0 & 11 \\ 68.4 & 73.3 & 77.8 & 80.9 & 85.3 & 92.2 & 95.6 & 95.5 & 12 \\ 62.9 & 67.3 & 71.5 & 74.6 & 78.4 & 84.0 & 86.7 & 86.0 & 13 \\ 1.0 & 1.4 & 1.5 & 1.7 & 1.8 & 1.9 & 2.0 & 2.1 & 14 \\ 4.5 & 4.6 & 4.8 & 4.6 & 5.1 & 6.3 & 7.0 & 7.4 & 15 \\ 64.2 & 68.1 & 71.4 & 73.6 & 74.6 & 79.5 & 86.6 & 89.9 & 16 \\ & & & & & & & & \\ \mathbf{4 9 8 . 3} & \mathbf{5 2 6 . 6} & \mathbf{5 5 2 . 0} & \mathbf{5 7 5 . 9} & \mathbf{6 1 0 . 9} & \mathbf{6 4 0 . 8} & \mathbf{6 5 0 . 6} & \mathbf{6 8 2 . 9} & \mathbf{1 7} \\ 189.8 & 201.7 & 216.1 & 236.1 & 250.3 & 272.2 & 273.9 & 253.0 & 18 \\ 13.6 & 12.5 & 10.8 & 10.4 & 9.8 & 11.0 & 13.2 & 13.5 & 19 \\ 217.6 & 224.3 & 227.6 & 235.8 & 252.4 & 271.7 & 305.1 & 332.3 & 20 \\ 224.1 & 234.1 & 246.6 & 266.8 & 290.8 & 315.4 & 350.8 & 384.2 & 21 \\ & & & & & & & & \\ \mathbf{7 0 8 . 1} & \mathbf{7 5 0 . 6} & \mathbf{7 9 8 . 0} & \mathbf{8 5 3 . 3} & \mathbf{9 0 9 . 3} & \mathbf{9 6 7 . 7} & \mathbf{9 8 3 . 4} & \mathbf{1 0 0 1 . 4} & \mathbf{2 2} \\ 696.1 & 724.8 & 758.9 & 801.4 & 858.9 & 917.8 & 966.1 & 1004.6 & 23 \\ & & & & & & & & \\ \mathbf{1 2 . 0} & \mathbf{2 5 . 8} & \mathbf{3 9 . 1} & \mathbf{5 2 . 0} & \mathbf{5 0 . 4} & \mathbf{5 0 . 0} & \mathbf{1 7 . 3} & \mathbf{- 3 . 2} & \mathbf{2 4}\end{array}$

$\begin{array}{rrrrrrrrr}\mathbf{4 4 . 4} & \mathbf{5 9 . 7} & \mathbf{7 4 . 4} & \mathbf{8 8 . 0} & \mathbf{9 0 . 3} & \mathbf{9 3 . 8} & \mathbf{6 5 . 8} & \mathbf{4 8 . 4} & \mathbf{2 5} \\ 12.0 & 25.8 & 39.1 & 52.0 & 50.4 & 50.0 & 17.3 & -3.2 & 26 \\ 32.4 & 33.9 & 35.3 & 36.0 & 39.9 & 43.7 & 48.5 & 51.7 & 27 \\ & & & & & & & & \\ \mathbf{7 7 . 4} & \mathbf{8 2 . 6} & \mathbf{9 3 . 2} & \mathbf{9 7 . 9} & \mathbf{1 1 2 . 6} & \mathbf{1 2 4 . 0} & \mathbf{1 2 6 . 8} & \mathbf{1 3 5 . 3} & \mathbf{2 8} \\ 154.0 & 163.8 & 178.9 & 186.5 & 206.1 & 225.1 & 235.8 & 248.4 & 29 \\ 83.1 & 87.2 & 91.6 & 96.2 & 102.1 & 109.8 & 117.7 & 121.7 & 30 \\ 6.6 & 6.1 & 5.9 & 7.6 & 8.6 & 8.8 & 8.6 & 8.6 & 31 \\ & & & & & & & & \\ \mathbf{- 3 3 . 0} & \mathbf{- 2 2 . 9} & \mathbf{- 1 8 . 8} & \mathbf{- 9 . 9} & \mathbf{- 2 2 . 3} & \mathbf{- 3 0 . 3} & \mathbf{- 6 1 . 0} & \mathbf{- 8 6 . 9} & \mathbf{3 2}\end{array}$

$\begin{array}{rrrrrrrrr}\mathbf{- 3 3 . 0} & \mathbf{- 2 2 . 9} & \mathbf{- 1 8 . 8} & \mathbf{- 9 . 9} & \mathbf{- 2 2 . 3} & \mathbf{- 3 0 . 3} & \mathbf{- 6 1 . 0} & \mathbf{- 8 6 . 9} & \mathbf{3 3} \\ \mathbf{- 3 1 . 7} & \mathbf{1 3 . 8} & \mathbf{2 5 . 4} & \mathbf{1 4 6 . 9} & \mathbf{7 7 . 5} & \mathbf{3 5 . 8} & \mathbf{9 1 . 5} & \mathbf{8 6 . 6} & \mathbf{3 4} \\ & & & & & & & & \\ \mathbf{1 0 . 0} & \mathbf{5 . 1} & \mathbf{1 0 . 2} & \mathbf{8 . 9} & \mathbf{1 4 . 9} & \mathbf{1 0 . 4} & \mathbf{1 2 . 7} & \mathbf{2 5 . 6} & \mathbf{3 5} \\ 3.4 & -5.5 & 4.4 & -3.9 & 3.9 & 1.0 & 5.1 & 8.5 & 36 \\ 6.6 & 10.6 & 5.8 & 12.8 & 11.0 & 9.4 & 7.7 & 17.1 & 37 \\ & & & & & & & & \\ \mathbf{- 9 4 . 7} & \mathbf{- 3 7 . 5} & \mathbf{- 3 . 6} & \mathbf{1 3 0 . 3} & \mathbf{2 4 . 1} & \mathbf{- 2 2 . 3} & \mathbf{5 5 . 9} & \mathbf{2 0 . 8} & \mathbf{3 8} \\ 17.1 & 20.3 & 14.3 & 28.0 & 6.9 & 22.6 & -26.5 & -3.8 & 39 \\ -80.2 & -32.8 & -17.7 & 30.0 & -2.5 & -29.1 & 50.2 & 22.1 & 40 \\ -35.1 & -35.3 & -0.8 & 63.6 & 11.0 & -18.0 & 19.9 & 2.1 & 41 \\ -3.5 & -0.5 & -0.7 & -1.4 & -1.5 & 0.6 & 0.3 & -1.4 & 42 \\ 7.1 & 10.7 & 1.3 & 10.2 & 10.1 & 1.7 & 11.9 & 1.8 & 43 \\ & & & & & & & & \\ \mathbf{0 . 3} & \mathbf{3 5 . 9} & \mathbf{7 . 2} & \mathbf{1 1 . 3} & \mathbf{9 . 3} & \mathbf{2 4 . 2} & \mathbf{- 8 . 7} & \mathbf{2 . 8} & \mathbf{4 4} \\ -3.0 & 32.1 & 3.6 & 7.2 & 5.0 & 19.7 & -13.4 & -2.1 & 45 \\ 3.3 & 3.8 & 3.7 & 4.1 & 4.3 & 4.5 & 4.7 & 5.0 & 46 \\ & & & & & & & & \\ \mathbf{1 8 . 0} & \mathbf{2 0 . 5} & \mathbf{9 . 4} & \mathbf{- 2 . 9} & \mathbf{7 . 8} & \mathbf{- 0 . 3} & \mathbf{2 7 . 9} & \mathbf{8 . 6} & \mathbf{4 7} \\ 12.1 & 14.5 & 16.8 & 9.4 & 3.5 & -1.2 & 22.8 & 6.7 & 48 \\ 5.9 & 6.0 & -7.4 & -12.3 & 4.3 & 0.8 & 5.1 & 2.0 & 49 \\ & & & & & & & & \\ \mathbf{3 4 . 6} & \mathbf{- 1 0 . 1} & \mathbf{2 . 1} & \mathbf{- 0 . 6} & \mathbf{2 1 . 5} & \mathbf{2 3 . 7} & \mathbf{3 . 6} & \mathbf{2 8 . 7} & \mathbf{5 0} \\ -9.1 & -4.6 & 0.3 & 2.8 & 10.5 & 14.8 & 3.6 & 10.4 & 51 \\ 43.7 & -5.5 & 1.9 & -3.5 & 11.0 & 8.9 & -0.0 & 18.4 & 52 \\ & & & & & & & \\ \mathbf{- 3 1 . 7} & \mathbf{1 5 . 0} & \mathbf{7 2 . 9} & \mathbf{9 8 . 2} & \mathbf{6 7 . 6} & \mathbf{4 2 . 8} & \mathbf{1 3 1 . 0} & \mathbf{1 6 8 . 4} & \mathbf{5 3} \\ & & & & & & & & \\ \mathbf{- 6 1 . 4} & \mathbf{- 1 6 . 2} & \mathbf{4 2 . 8} & \mathbf{6 6 . 5} & \mathbf{3 8 . 9} & \mathbf{1 6 . 5} & \mathbf{1 0 5 . 5} & \mathbf{1 4 3 . 4} & \mathbf{5 4} \\ 1.2 & 6.3 & 8.3 & -6.3 & 2.6 & 1.4 & 23.8 & 25.2 & 55 \\ -62.6 & -22.5 & 34.4 & \mathbf{7 2 . 7} & 36.3 & 15.1 & 81.7 & 118.2 & 56 \\ & & & & & & & & \\ \mathbf{0 . 5} & \mathbf{0 . 4} & \mathbf{- 1 . 2} & \mathbf{1 . 2} & \mathbf{- 0 . 4} & \mathbf{- 1 . 0} & \mathbf{0 . 2} & \mathbf{0 . 5} & \mathbf{5 7}\end{array}$


8. State and Local Governments (1)

Billions of dollars

$\begin{array}{llllllll}1995 & 1996 & 1997 & 1998 & 1999 & 2000 & 2001 & 2002\end{array}$

58 Other accounts payable (trade payables)

Memo:

59 Net lending or borrowing, financial account (lines 34-53)

OTHER CHANGES IN VOLUME ACCOUNT:

60 Total other volume changes

61 Other volume changes

62 Less statistical discrepancy (lines 32-[34-53])

\section{REVALUATION ACCOUNT:}

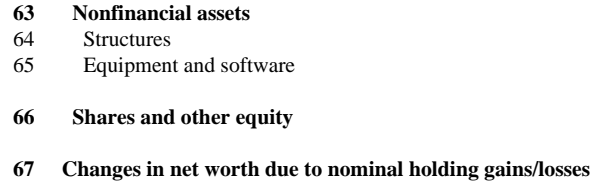

CHANGES IN BALANCE SHEET ACCOUNT:

68 Change in net worth (lines $28+32+60+67$ ) ***

BALANCE SHEET ACCOUNT (end of period):

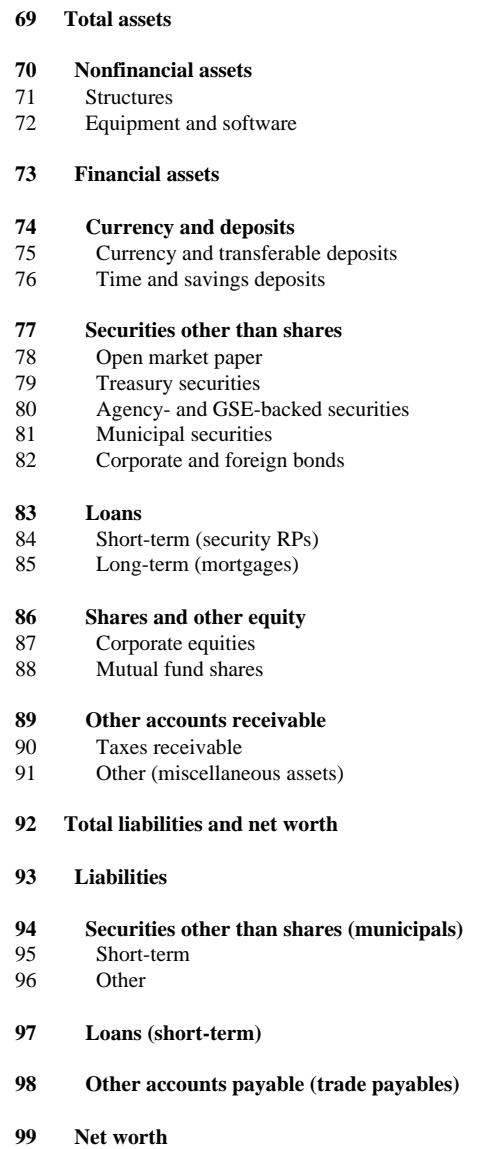

$\begin{array}{rrrrrrrrr}\mathbf{2 9 . 2} & \mathbf{3 0 . 9} & \mathbf{3 1 . 4} & \mathbf{3 0 . 5} & \mathbf{2 9 . 1} & \mathbf{2 7 . 4} & \mathbf{2 5 . 2} & \mathbf{2 4 . 5} & \mathbf{5 8} \\ & & & & & & & & \\ 0.0 & -1.2 & -47.5 & 48.8 & 9.9 & -7.1 & -39.5 & -81.7 & 59 \\ & & & & & & & & \\ & & & & & & & & \\ \mathbf{2 9 . 6} & \mathbf{1 5 . 5} & \mathbf{- 4 4 . 0} & \mathbf{4 5 . 1} & \mathbf{2 2 . 6} & \mathbf{2 2 . 0} & \mathbf{3 3 . 1} & \mathbf{2 5 . 2} & \mathbf{6 0} \\ -3.5 & -6.2 & -15.3 & -13.7 & -9.5 & -1.2 & 11.6 & 20.1 & 61 \\ -33.1 & -21.7 & 28.7 & -58.7 & -32.1 & -23.2 & -21.5 & -5.2 & 62\end{array}$

$\begin{array}{rrrrrrrrr}\mathbf{9 8 . 1} & \mathbf{8 0 . 3} & \mathbf{1 0 1 . 2} & \mathbf{8 6 . 5} & \mathbf{1 3 2 . 1} & \mathbf{1 7 5 . 6} & \mathbf{9 0 . 7} & \mathbf{9 7 . 0} & \mathbf{6 3} \\ 96.2 & 81.3 & 104.1 & 88.6 & 132.5 & 175.5 & 83.8 & 90.0 & 64 \\ 1.9 & -0.9 & -2.9 & -2.1 & -0.4 & 0.0 & 6.9 & 7.0 & 65 \\ \mathbf{3 . 5} & \mathbf{6 . 2} & \mathbf{1 5 . 3} & \mathbf{1 3 . 7} & \mathbf{9 . 5} & \mathbf{1 . 2} & \mathbf{- 1 1 . 6} & \mathbf{- 2 0 . 1} & \mathbf{6 6} \\ & & & & & & & & \\ \mathbf{1 0 1 . 5} & \mathbf{8 6 . 5} & \mathbf{1 1 6 . 5} & \mathbf{1 0 0 . 1} & \mathbf{1 4 1 . 6} & \mathbf{1 7 6 . 8} & \mathbf{7 9 . 1} & \mathbf{7 6 . 9} & \mathbf{6 7}\end{array}$

$\begin{array}{lllllllll}175.5 & 161.7 & 146.9 & 233.2 & 254.6 & 292.5 & 178.0 & 150.5 & 68\end{array}$

\begin{tabular}{|c|c|c|c|c|c|c|c|}
\hline 4212.7 & 4389.5 & 4609.3 & 4940.6 & 5262.8 & 5598.1 & 5907.1 & 6226.0 \\
\hline 3218.6 & 3381.5 & 3575.9 & 3760.3 & 4005.0 & 4304.6 & 4522.1 & 4754.4 \\
\hline 3059.7 & 3213.9 & 3400.8 & 3574.6 & 3805.6 & 4091.2 & 4288.7 & 4501.0 \\
\hline 158.9 & 167.7 & 175.1 & 185.7 & 199.4 & 213.4 & 233.4 & 253.4 \\
\hline 994.1 & 1007.9 & 1033.3 & 1180.3 & 1257.8 & 1293.5 & 1385.0 & 1471.6 \\
\hline 95.3 & 100.3 & 110.5 & 119.4 & 134.3 & 144.7 & 157.4 & 183.0 \\
\hline 33.3 & 27.8 & 32.2 & 28.3 & 32.2 & 33.2 & 38.2 & 46.7 \\
\hline 62.0 & 72.6 & 78.4 & 91.1 & 102.1 & 111.5 & 119.2 & 136.3 \\
\hline 524.8 & 487.2 & 483.7 & 614.0 & 638.1 & 615.8 & 671.6 & 692.4 \\
\hline 39.4 & 59.7 & 74.0 & 102.0 & 108.9 & 131.5 & 105.0 & 101.2 \\
\hline 289.8 & 257.0 & 239.3 & 269.3 & 266.8 & 237.7 & 287.9 & 310.0 \\
\hline 151.5 & 116.2 & 115.4 & 179.0 & 190.0 & 172.0 & 191.9 & 194.0 \\
\hline 5.1 & 4.6 & 3.9 & 2.5 & 1.0 & 1.6 & 1.9 & 0.5 \\
\hline 39.0 & 49.7 & 51.0 & 61.2 & 71.3 & 73.0 & 84.9 & 86.7 \\
\hline 229.5 & 265.4 & 272.7 & 284.0 & 293.3 & 317.5 & 308.8 & 311.7 \\
\hline 115.7 & 147.8 & 151.4 & 158.5 & 163.5 & 183.3 & 169.9 & 167.7 \\
\hline 113.8 & 117.6 & 121.3 & 125.4 & 129.8 & 134.3 & 139.0 & 143.9 \\
\hline 61.2 & 87.9 & 112.6 & 123.3 & 140.6 & 141.5 & 157.8 & 146.4 \\
\hline 26.2 & 46.8 & 79.0 & 102.0 & 115.0 & 115.1 & 126.3 & 112.9 \\
\hline 35.0 & 41.0 & 33.6 & 21.3 & 25.6 & 26.4 & 31.5 & 33.5 \\
\hline 83.4 & 67.1 & 53.9 & 39.6 & 51.6 & 74.1 & 89.3 & 138.2 \\
\hline 27.9 & 26.1 & 26.9 & 28.1 & 33.5 & 45.6 & 50.1 & 59.5 \\
\hline 55.4 & 41.0 & 27.0 & 11.5 & 18.1 & 28.5 & 39.2 & 78.6 \\
\hline 4212.7 & 4389.5 & 4609.3 & 4940.6 & 5262.8 & 5598.1 & 5907.1 & 6226.0 \\
\hline 1531.7 & 1546.7 & 1619.7 & 1717.8 & 1785.4 & 1828.3 & 1959.2 & 2127.6 \\
\hline 1035.3 & 1019.0 & 1061.8 & 1128.2 & 1167.1 & 1183.6 & 1289.2 & 1432.6 \\
\hline 32.9 & 39.1 & 47.5 & 41.2 & 43.7 & 45.1 & 69.0 & 94.2 \\
\hline 1002.4 & 979.9 & 1014.3 & 1087.1 & 1123.4 & 1138.5 & 1220.2 & 1338.4 \\
\hline 9.8 & 10.1 & 8.9 & 10.1 & 9.7 & 8.7 & 8.9 & 9.4 \\
\hline 486.7 & 517.6 & 549.0 & 579.5 & 608.6 & 635.9 & 661.1 & 685.6 \\
\hline 681.0 & 2842.7 & 2989.6 & 3222.8 & 3477.3 & 3769.8 & 3947.8 & 4098.4 \\
\hline
\end{tabular}

1) Does not include employee retirement funds.

* The discrepancy is the difference between net lending or borrowing derived in the capital account and the same concept derived in the financial account. The discrepancy reflects differences in source data, timing of recorded flows, and other statistical differences between the capital and financial accounts.

** Partial--Does not include revaluation of tangible assets. 


\section{Rest of the World}

Billions of dollars

\section{CURRENT ACCOUNT:}

Foreign income from U.S.

U.S. imports of goods and services

U.S. income payments to rest of world

Current taxes and trans. payments to rest of world

5 Foreign outlays to U.S.

6 U.S. exports of goods and service

U.S. income receipts from rest of world

8 Equals net saving (current external balance)

CAPITAL ACCOUNT:

9 Net saving

10 Net capital transfers

11 Less acq. of nonproduced nonfinancial assets

12 Net lending or borrowing, capital account (lines 9+10-11)

FINANCIAL ACCOUNT:

13 Net lending or borrowing (line 12)

14 Net acquisition of U.S. financial assets

15 Monetary gold and SDRs

16 Currency and deposits

17 Currency

18 Transferable deposits

19 Time deposits

20 Net interbank items due from U.S. banks

Securities other than shares

Open market paper

Treasury securities

Agency- and GSE-backed securities

Corporate bonds

Loans (short-term)

Security RPs

Loans to U.S. corporate busines

Shares and other equity

Corporate equities

Foreign direct investment in U.S

Other accounts receivable

Trade receivables

Other (miscellaneous assets)

35 Net incurrence of liabilities

Currency and deposits

Official foreign exchange

Net IMF position

U.S. private deposits

U.S. government deposits

1 Securities other than shares

42 Commercial paper

43 Bonds

44 Loans (short-term)

45 Acceptance liabilities to banks

46 U.S. government loans

Bank loans n.e.c.

8 Shares and other equity

49 Corporate equities

50 U.S. government equity in IBRD, etc

U.S. direct investment abroad

52 Other accounts payable

53 Trade payables

54 Other (miscellaneous liabilities)

Memo:

55 Net lending, financial account (lines 14-35) $\begin{array}{llllllll}1995 & 1996 & 1997 & 1998 & 1999 & 2000 & 2001 & 2002\end{array}$ 


\section{Rest of the World}

Billions of dollars

$\begin{array}{llllllll}1995 & 1996 & 1997 & 1998 & 1999 & 2000 & 2001 & 2002\end{array}$

OTHER CHANGES IN VOLUME ACCOUNT

56 Total other volume changes

57 Other volume changes

58 Less statistical discrepancy (lines 12-[14-35]) *

$\begin{array}{rrrrrrrrr}\mathbf{- 6 0 . 0} & \mathbf{8 6 . 9} & \mathbf{- 5 6 . 8} & \mathbf{- 2 0 2 . 2} & \mathbf{- 2 6 4 . 0} & \mathbf{2 3 8 . 9} & \mathbf{5 0 . 9} & \mathbf{- 3 9 . 9} & \mathbf{5 6} \\ -54.5 & 50.0 & -165.2 & -89.1 & -217.0 & 180.8 & 15.9 & -101.3 & 57 \\ 5.6 & -36.9 & -108.4 & 113.1 & 47.1 & -58.1 & -35.0 & -61.3 & 58\end{array}$

REVALUATION ACCOUNT:

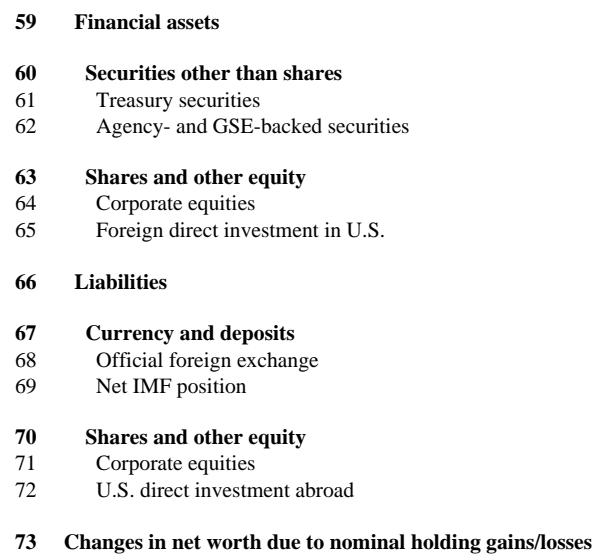

$\begin{array}{rrrrrrrrr}\mathbf{1 7 0 . 2} & \mathbf{5 7 . 4} & \mathbf{1 8 5 . 0} & \mathbf{2 6 1 . 0} & \mathbf{1 1 1 . 5} & \mathbf{- 3 6 0 . 0} & \mathbf{- 2 8 5 . 0} & \mathbf{- 2 2 2 . 2} & \mathbf{5 9} \\ \mathbf{3 0 . 6} & \mathbf{- 3 3 . 5} & \mathbf{- 1 . 4} & \mathbf{8 . 0} & \mathbf{- 6 3 . 3} & \mathbf{4 0 . 6} & \mathbf{1 2 . 7} & \mathbf{4 4 . 1} & \mathbf{6 0} \\ 27.1 & -35.6 & -5.3 & 0.6 & -72.2 & 32.9 & 10.3 & 35.2 & 61 \\ 3.5 & 2.1 & 3.9 & 7.4 & 8.9 & 7.7 & 2.5 & 8.9 & 62 \\ & & & & & & & & \\ \mathbf{1 3 9 . 6} & \mathbf{9 0 . 9} & \mathbf{1 8 6 . 4} & \mathbf{2 5 3 . 0} & \mathbf{1 7 4 . 8} & \mathbf{- 4 0 0 . 6} & \mathbf{- 2 9 7 . 7} & \mathbf{- 2 6 6 . 3} & \mathbf{6 3} \\ 135.3 & 111.8 & 213.5 & 255.5 & 248.9 & -179.5 & -213.1 & -364.4 & 64 \\ 4.3 & -20.9 & -27.1 & -2.5 & -74.1 & -221.1 & -84.6 & 98.2 & 65 \\ & & & & & & & & \\ \mathbf{9 5 . 4} & \mathbf{1 6 8 . 9} & \mathbf{1 0 4 . 3} & \mathbf{1 5 5 . 7} & \mathbf{4 0 6 . 6} & \mathbf{- 3 0 5 . 1} & \mathbf{- 4 0 4 . 4} & \mathbf{- 2 7 0 . 1} & \mathbf{6 6} \\ & & & & & & & & \\ \mathbf{1 1 . 3} & \mathbf{1 3 . 2} & \mathbf{- 1 6 . 4} & \mathbf{4 . 6} & \mathbf{- 1 . 2} & \mathbf{- 3 . 6} & \mathbf{- 3 . 5} & \mathbf{- 0 . 9} & \mathbf{6 7} \\ 1.5 & -3.2 & -4.6 & 3.7 & -0.6 & -2.8 & -2.9 & 1.0 & 68 \\ 0.2 & -0.5 & -0.9 & 0.9 & -0.7 & -0.8 & -0.6 & -1.9 & 69 \\ & & & & & & & & \\ \mathbf{8 4 . 1} & \mathbf{1 5 5 . 7} & \mathbf{1 2 0 . 7} & \mathbf{1 5 1 . 2} & \mathbf{4 0 7 . 8} & \mathbf{- 3 0 1 . 4} & \mathbf{- 4 0 0 . 9} & \mathbf{- 2 6 9 . 2} & \mathbf{7 0} \\ 83.9 & 143.3 & 147.3 & 165.8 & 414.4 & -257.6 & -349.3 & -285.2 & 71 \\ 0.2 & 12.4 & -26.6 & -14.7 & -6.6 & -43.8 & -51.6 & 15.9 & 72 \\ & & & & & & & & \\ \mathbf{7 4 . 7} & \mathbf{- 1 1 1 . 5} & \mathbf{8 0 . 7} & \mathbf{1 0 5 . 3} & \mathbf{- 2 9 5 . 1} & \mathbf{- 5 4 . 9} & \mathbf{1 1 9 . 4} & \mathbf{4 7 . 9} & \mathbf{7 3}\end{array}$

CHANGES IN BALANCE SHEET ACCOUNT:

74 Change in net worth (lines $12+56+73$ )

FINANCIAL BALANCE SHEET ACCOUNT (end of period):

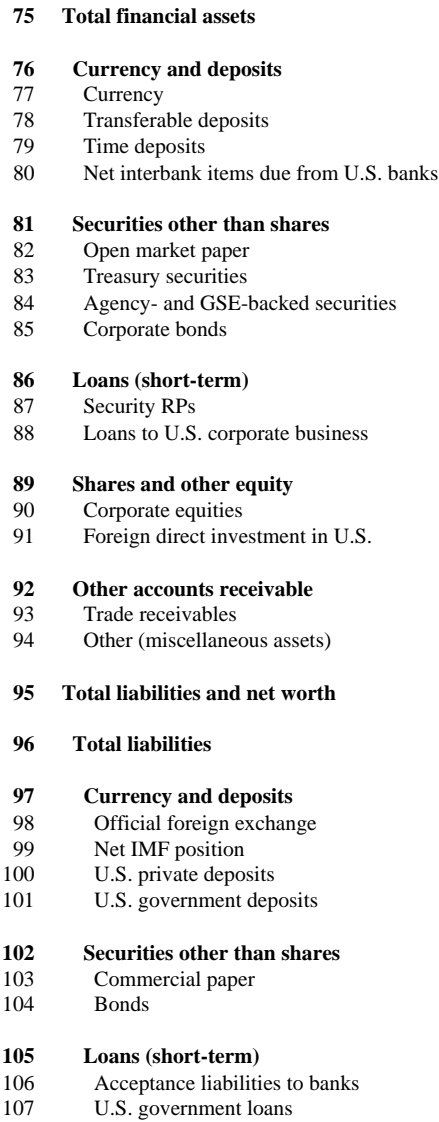

\begin{tabular}{|c|c|c|c|c|c|c|c|}
\hline 3434.5 & 4042.1 & 4627.3 & 5199.8 & 5819.9 & 6590.6 & 6979.2 & 7375.3 \\
\hline 472.7 & 451.6 & 490.2 & 490.9 & 540.1 & 558.7 & 517.1 & 556.5 \\
\hline 169.2 & 186.6 & 211.4 & 228.0 & 254.6 & 259.9 & 283.7 & 305.2 \\
\hline 24.5 & 27.1 & 32.2 & 30.4 & 43.7 & 34.2 & 34.6 & 36.3 \\
\hline 49.6 & 60.6 & 73.6 & 86.6 & 101.6 & 103.5 & 83.3 & 95.3 \\
\hline 229.3 & 177.3 & 173.0 & 145.9 & 140.3 & 161.1 & 115.5 & 119.7 \\
\hline 1371.3 & 1713.5 & 1954.4 & 2135.9 & 2235.1 & 2503.8 & 2837.9 & 3310.9 \\
\hline 43.4 & 57.9 & 77.8 & 115.3 & 102.3 & 111.9 & 118.1 & 135.4 \\
\hline 820.2 & 1047.3 & 1165.7 & 1185.0 & 1080.4 & 1026.1 & 1039.7 & 1214.2 \\
\hline 146.2 & 175.1 & 209.4 & 227.8 & 300.2 & 445.2 & 553.8 & 669.4 \\
\hline 361.5 & 433.2 & 501.6 & 607.8 & 752.1 & 920.6 & 1126.3 & 1291.9 \\
\hline 189.7 & 196.9 & 234.1 & 214.3 & 199.5 & 208.7 & 266.4 & 316.0 \\
\hline 67.6 & 70.9 & 90.8 & 72.0 & 79.9 & 91.3 & 150.7 & 190.1 \\
\hline 122.1 & 126.0 & 143.3 & 142.3 & 119.5 & 117.3 & 115.7 & 125.8 \\
\hline 1229.6 & 1418.0 & 1777.0 & 2251.0 & 2827.5 & 2941.8 & 2917.1 & 2743.7 \\
\hline 549.5 & 672.4 & 952.9 & 1250.3 & 1611.5 & 1625.6 & 1533.9 & 1222.7 \\
\hline 680.1 & 745.6 & 824.1 & 1000.7 & 1216.0 & 1316.2 & 1383.2 & 1521.0 \\
\hline 171.2 & 262.2 & 171.6 & 107.7 & 17.6 & 377.6 & 440.5 & 448.2 \\
\hline 52.6 & 58.1 & 59.0 & 52.5 & 47.4 & 47.0 & 43.9 & 47.0 \\
\hline 118.6 & 204.1 & 112.6 & 55.2 & -29.7 & 330.6 & 396.7 & 401.2 \\
\hline 3434.5 & 4042.1 & 4627.3 & 5199.8 & 5819.9 & 6590.6 & 6979.2 & 7375.3 \\
\hline 2788.5 & 3319.7 & 3769.8 & 4251.1 & 5151.6 & 5340.9 & $\mathbf{5 1 7 9 . 5}$ & 5102.3 \\
\hline 484.8 & 577.6 & 669.5 & 687.0 & 738.8 & 869.0 & 900.4 & 933.4 \\
\hline 49.1 & 38.3 & 30.8 & 36.0 & 32.2 & 31.2 & 29.0 & 33.8 \\
\hline 14.6 & 15.4 & 18.1 & 24.1 & 18.0 & 14.8 & 17.9 & 22.0 \\
\hline 418.8 & 521.7 & 618.5 & 624.9 & 686.1 & 820.3 & 851.0 & 874.9 \\
\hline 2.3 & 2.2 & 2.1 & 2.0 & 2.6 & 2.6 & 2.6 & 2.7 \\
\hline 355.5 & 433.8 & 492.8 & 523.5 & 541.7 & 588.6 & 549.9 & 552.6 \\
\hline 56.2 & 67.5 & 65.1 & 72.9 & 89.2 & 120.9 & 106.7 & 142.8 \\
\hline 299.4 & 366.3 & 427.7 & 450.6 & 452.5 & 467.7 & 443.2 & 409.8 \\
\hline 98.1 & 108.3 & 115.1 & 115.8 & 110.8 & 120.9 & 109.8 & 113.0 \\
\hline 8.2 & 9.9 & 9.7 & 4.7 & 3.9 & 3.1 & 0.5 & 0.2 \\
\hline 55.4 & 54.7 & 53.2 & 52.4 & 47.8 & 47.2 & 46.0 & 44.3 \\
\hline
\end{tabular}




\section{Rest of the World}

Billions of dollars

\begin{tabular}{|c|c|c|c|c|c|c|c|c|c|c|}
\hline & & 1995 & 1996 & 1997 & 1998 & 1999 & 2000 & 2001 & 2002 & \\
\hline 108 & Bank loans n.e.c. & 34.6 & 43.7 & 52.1 & 58.7 & 59.2 & 70.5 & 63.2 & 68.6 & 108 \\
\hline 109 & Shares and other equity & 1689.7 & 2022.0 & 2306.7 & 2703.4 & 3451.9 & 3417.9 & 3247.8 & 3135.8 & 109 \\
\hline 110 & U.S. government equity in IBRD, etc. & 27.4 & 29.2 & 30.8 & 32.4 & 33.9 & 35.4 & 37.1 & 38.7 & 110 \\
\hline 111 & U.S. direct investment abroad & 885.5 & 989.8 & 1068.1 & 1196.0 & 1414.4 & 1529.7 & 1598.1 & 1751.9 & 111 \\
\hline 112 & Corporate equities & 776.8 & 1002.9 & 1207.8 & 1475.0 & 2003.7 & 1852.9 & 1612.7 & 1345.2 & 112 \\
\hline 113 & Other accounts payable & 160.3 & 178.0 & 185.7 & 221.4 & 308.4 & 344.5 & 371.6 & 367.6 & 113 \\
\hline 114 & Trade payables & 45.3 & 43.6 & 48.8 & 44.9 & 49.1 & 49.9 & 47.8 & 37.6 & 114 \\
\hline 115 & Other (miscellaneous liabilities) & 115.0 & 134.4 & 136.9 & 176.5 & 259.3 & 294.6 & 323.8 & 330.0 & 115 \\
\hline 116 & Net worth (external account) & 646.0 & 722.4 & 857.5 & 948.7 & 668.3 & 1249.7 & 1799.6 & 2273.0 & 116 \\
\hline
\end{tabular}

* The discrepancy is the difference between net lending or borrowing derived in the capital account and the same concept derived in the financial account. The discrepancy reflects differences in source data, timing of recorded flows, and other statistical differences between the capital and financial accounts. 
Chart 1: Measures of Household Sector Saving and Net Worth as a Percent of Disposable Income

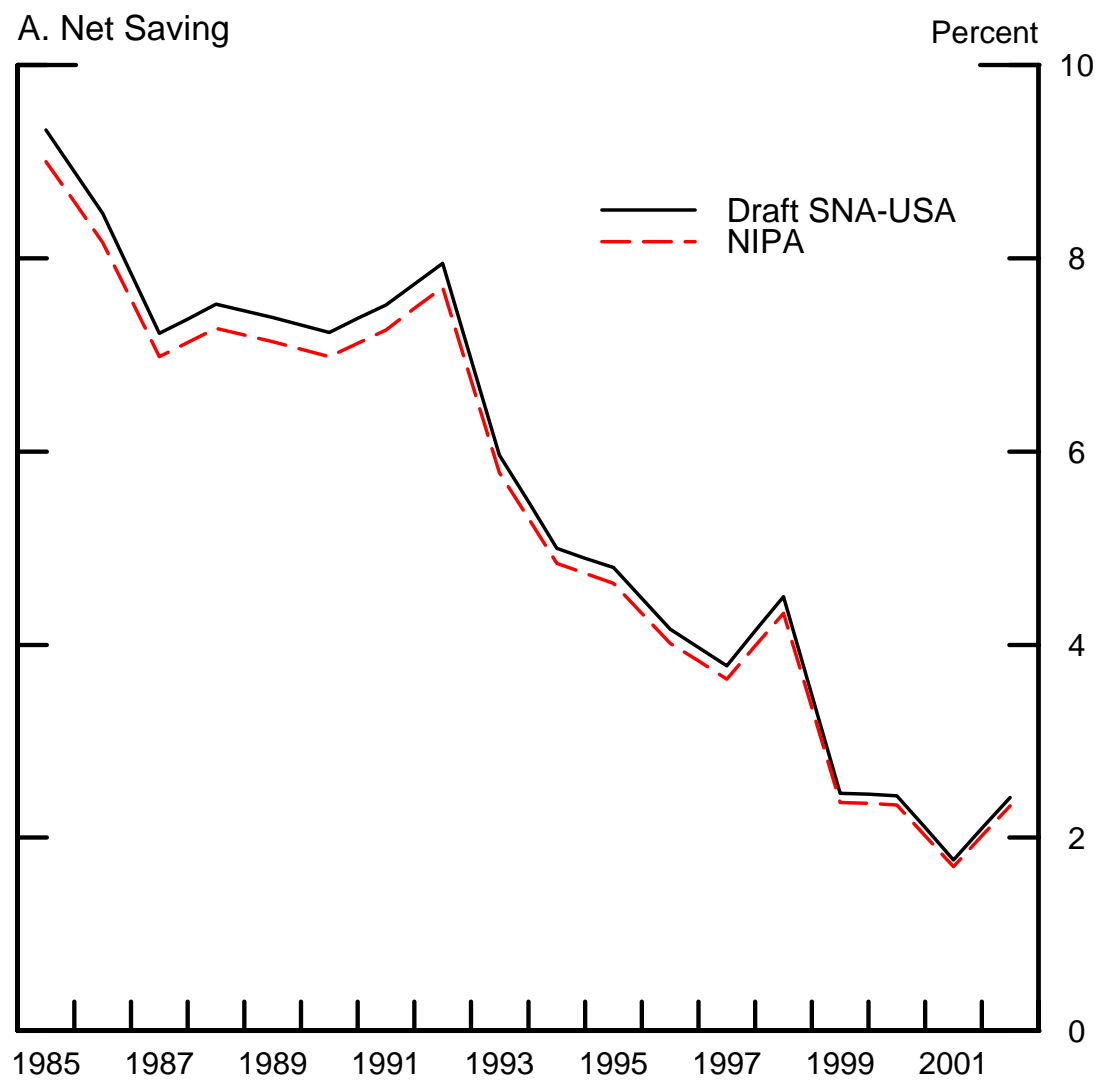

B. Change in net worth

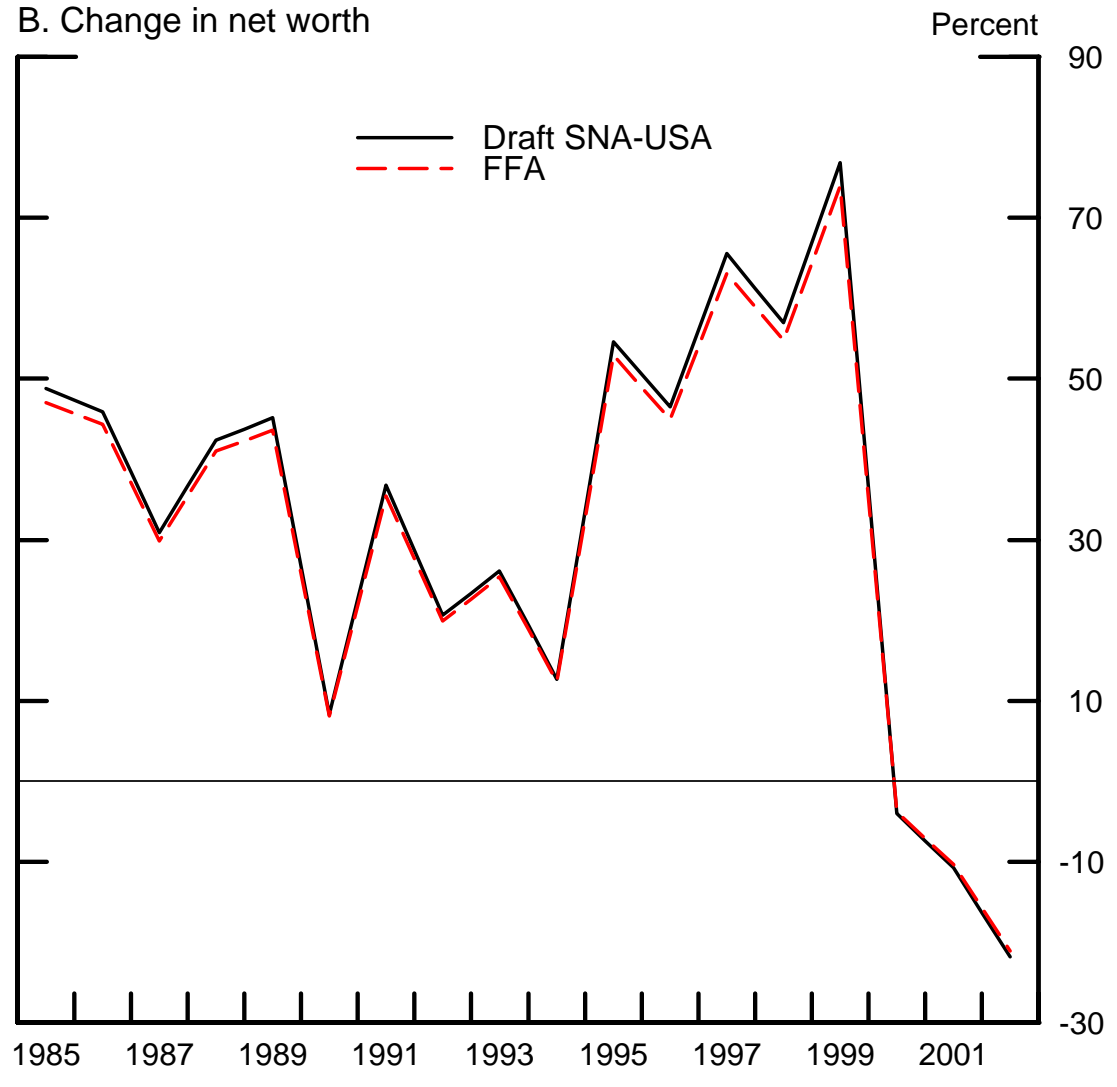


Chart 2: Alternative Concepts of Net Worth for the Nonfinancial Corporate Business Sector

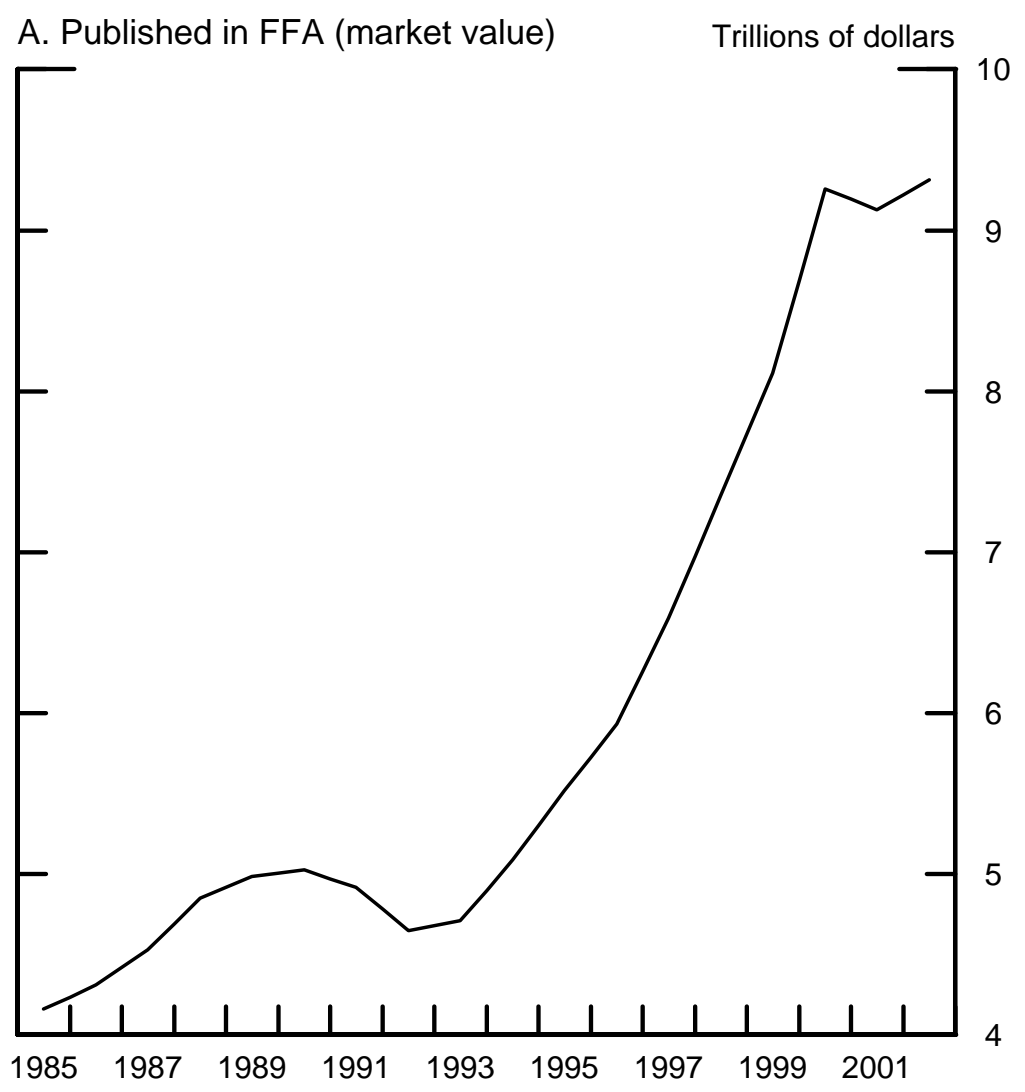

B. From Draft SNA-USA

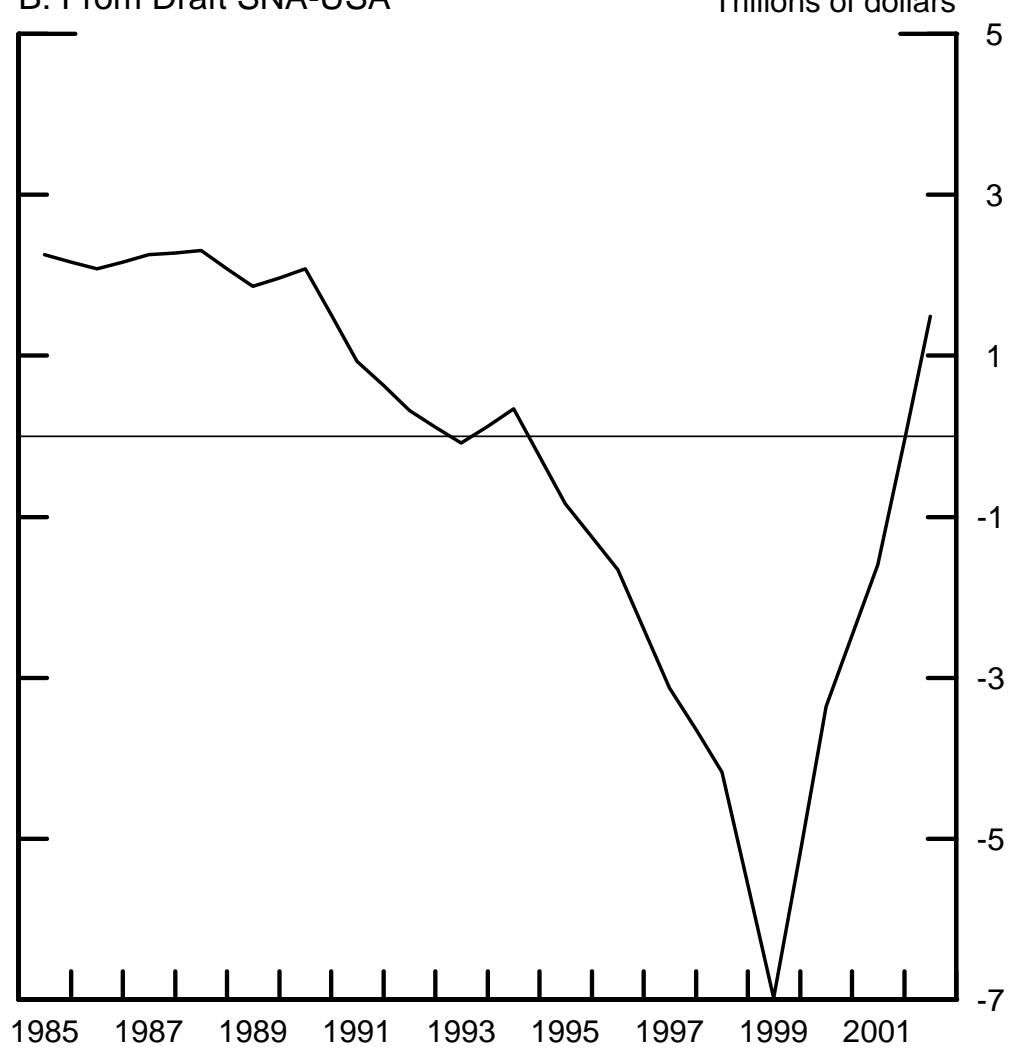




\section{Chart 3: Net Lending / Net Borrowing in Draft SNA-USA}

A. Households and Nonprofit Institutions

Serving Households

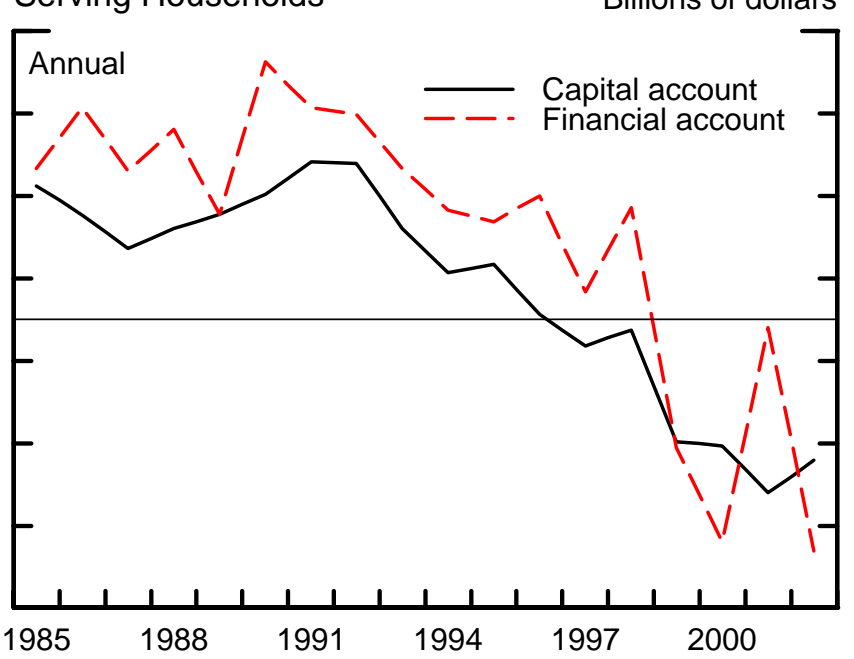

350

250

150

50

$-50$

$-150$

$-250$

$-350$
C. Federal Government

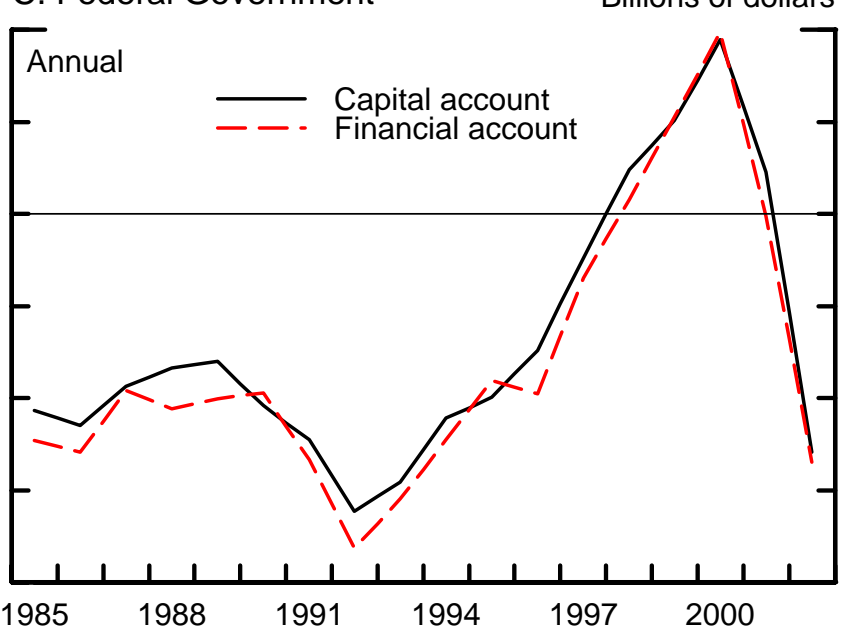

B. Nonfinancial Corporate Business Billions of dollars

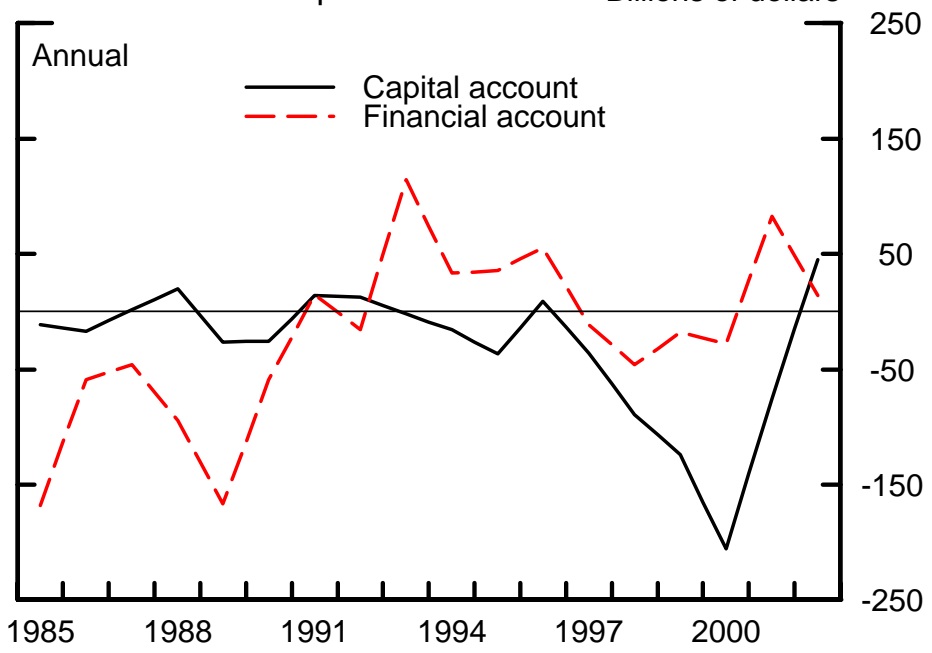

D. State and Local Governments Billions of dollars

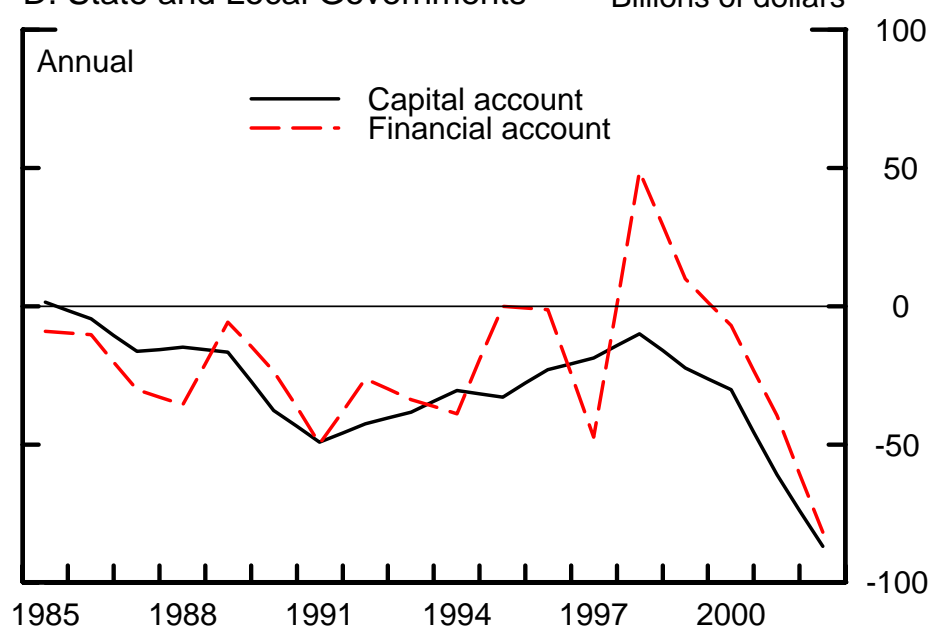

F. Rest Of The World

Billions of dollars

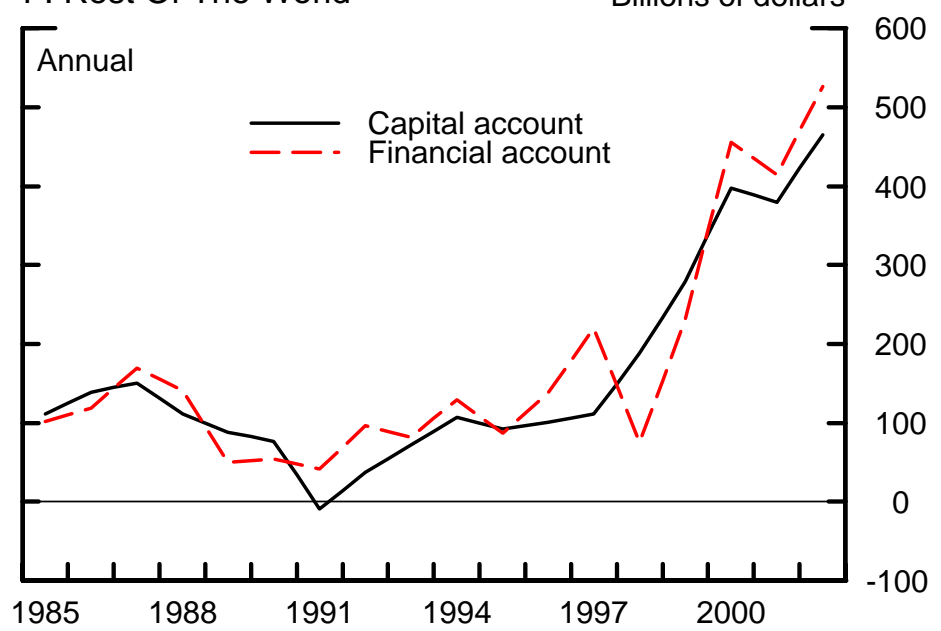

E. Financial Business

Billions of dollars

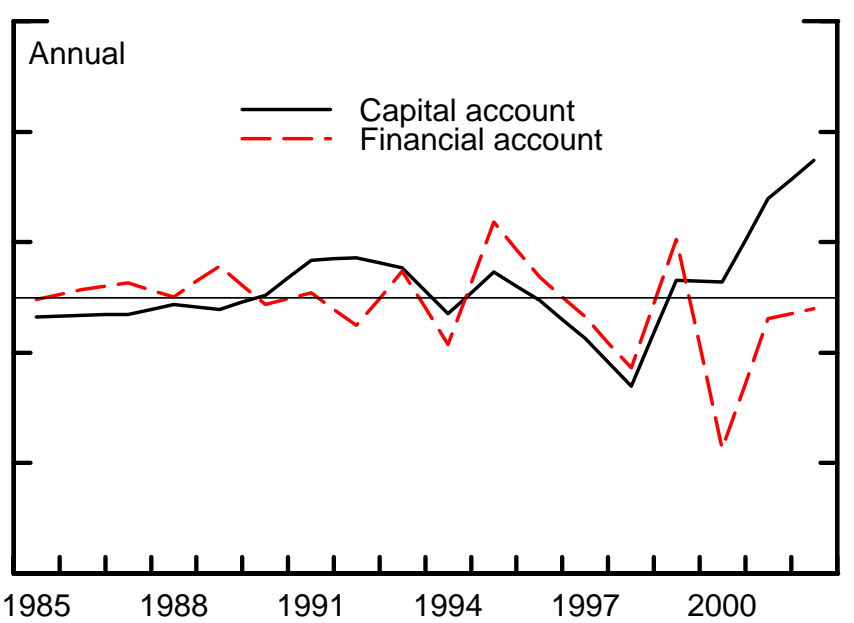

250

150

50

$-50$

$-150$

$-250$
200

100

0

$-100$

$-200$

$-300$

400

.


Chart 4: Net Lending / Net Borrowing for Combined Financial and Nonfinancial Corporate Business

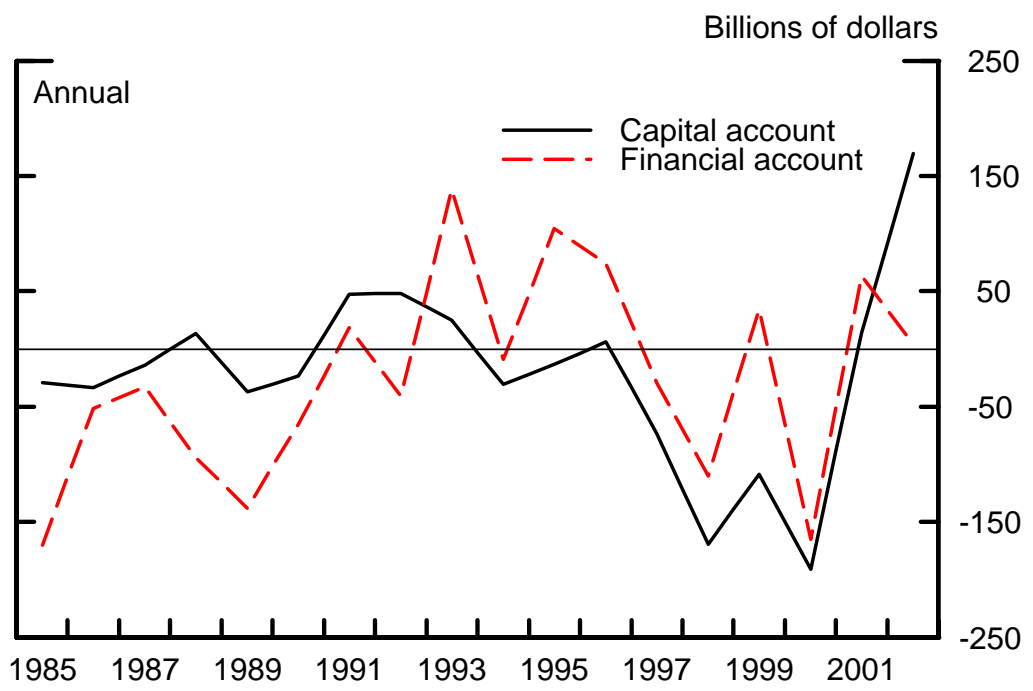

